\title{
SUBSTITUIÇÃO DE FONTES PROTÉICAS DE ORIGEM ANIMAL POR FONTES PROTÉICAS DE ORIGEM VEGETAL EM RAÇÕES PARA O “BLACK BASS”' Micropterus salmoides
}

\section{ANA MARIA BARRETTO DE MENEZES SAMPAIO DE OLIVEIRA}

\author{
Tese apresentada à Escola Superior de Agricultura \\ “Luiz de Queiroz”, Universidade de São Paulo, para \\ obtenção de título de Doutor em Agronomia, Área de \\ Concentração: Ciência Animal e Pastagens.
}

PIRACICABA

Estado de São Paulo - Brasil

Maio - 2003 


\title{
SUBSTITUIÇÃO DE FONTES PROTÉICAS DE ORIGEM ANIMAL POR FONTES PROTÉICAS DE ORIGEM VEGETAL EM RAÇÕES PARA O \\ “BLACK BASS”' Micropterus salmoides
}

\author{
ANA MARIA BARRETTO DE MENEZES SAMPAIO DE OLIVEIRA \\ Engenheiro Agrônomo
}

Orientador: Prof. Dr. JOSÉ EURICO POSSEBON CYRINO

Tese apresentada à Escola Superior de Agricultura

"Luiz de Queiroz”, Universidade de São Paulo, para obtenção de título de Doutor em Agronomia, Área de Concentração: Ciência Animal e Pastagens.

PIRACICABA

Estado de São Paulo- Brasil

Maio - 2003 


\section{Dados Internacionais de Catalogação na Publicação (CIP)}

DIVISÃO DE BIBLIOTECA E DOCUMENTAÇÃO - ESALQ/USP

Oliveira, Ana Maria Barretto de Menezes Sampaio de

Substituição de fontes protéic as de origem animal por fontes protéicas de origem vegetal em rações para o "Black Bass" Mic ropterus sa Imoides / Piracicaba, 2003.

$103 \mathrm{p}$.

Tese (doutorado) - - Escola Superior de Agric ultura Luiz de Queiroz, 2003.

Bibliografia.

1. Dieta a nimal 2. Digestibilida de 3. Nutrição a nimal 4. Peixes de água doc 5. Proteínas na dieta 7. Ração ba lanceada I. Título

CDD 639.3758

"Permitida a cópia total ou parcial deste documento, desde que citada a fonte - O autor" 
Aos me us pais Maria Bernarde te e Wilson pela educação, confiança e estimulos constantes em todos os momentos da minha vida e ao meu marido Raphael pelo apoio, carintho e de dic ação em todos esses anos que estamos juntos

“Ao meu avô Francisco Barretto de Menezes (in memorian) Da semente à vida Da vida àsemente" 


\section{AGRADECIMENTOS}

Aos meus pais pela educação e estímulos constantes;

Ao meu marido Raphael Bozola de Oliveira pelo carinho, confiança e apoio decisivos neste período;

Ao Prof. Dr. José Eurico Possebon Cyrino, pela orientação, amizade, confiança e oportunidade de realização deste trabalho;

Aos meus irmãos Bernardete B. M. Sampaio Freire, Wilson B. M. Sampaio e Ana Teresa B. M. Sampaio e à minha avó Mafalda Prícoli Barretto de Menezes;

As amigas, Luciana Viriato Saboya e Luciane Conte pelo apoio, incentivo e pela grande amizade;

À Fundação de Amparo a Pesquisa do Estado de São Paulo - FAPESP, pela outorga da bolsa de estudos e pela concessão dos recursos financeiros ao projeto que originou este trabalho;

Ao Prof. Dr. Irineu Umberto Packer, ESALQ/USP, pelo auxílio na análise estatística e contribuição à pesquisa ;

Ao corpo docente do Departamento de Zootecnia não Ruminantes e ao curso de Pós-Graduação em Ciência Animal e Pastagens da Escola Superior de Agricultura "Luiz de Queiroz" da Universidade de São Paulo pela oportunidade de realizar este curso;

Ao Prof. Dr. Luiz Edivaldo Pezzato e à Profa. Dra. Margarida Barros Ferreira Lima, UNESP-Botucatu, pelo auxílio nas análises químicas e interpretação dos resultados;

À Profa. Dra. Elisabeth Criscuolo Urbinati, CAUNESP-Jaboticabal, pelo auxílio nas análises químicas; 
À Profa. Dra. Marília Oetterer, ESALQ/USP, no auxílio da fabricação da silagem de peixe;

Aos funcionários do Setor de Piscicultura, Ismael Baldessin Júnior e Sérgio Pena, pela ajuda na montagem da estrutura e na condução dos experimentos;

À Nutron Alimentos Ltda, pela doação dos ingredientes e à gerente técnica comercial Alexsandra Carmen Caseiro pelo apoio e uso dos recursos de formulação de rações;

À equipe da $\mathrm{CBO}$, na pessoa de Oneida Vasconcelos Vieira, pela condução das análises químicas.

Aos pós-graduandos Andréa Belém Costa, Daniela Baconni e Leandro Portz;

Um agradecimento sincero a todas as demais pessoas que, direta ou indiretamente contribuíram para a realização deste trabalho. 


\section{SUMÁRIO}

Página

LISTA DE FIGURAS …........................................................................... viii

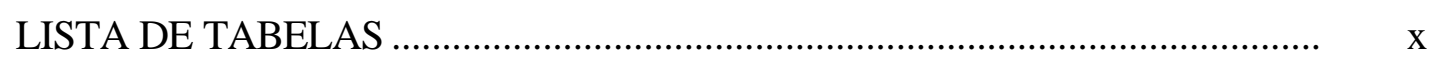

LISTA DE ANEXOS ............................................................................. xii

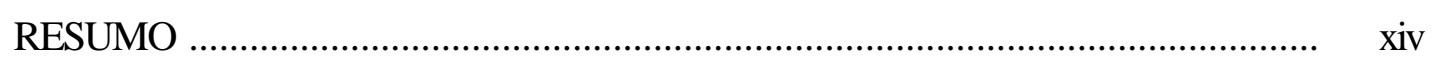

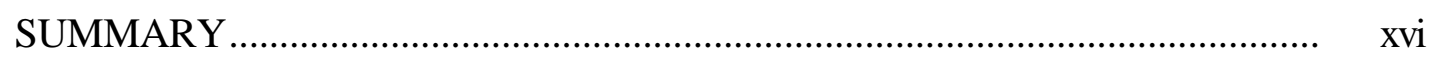

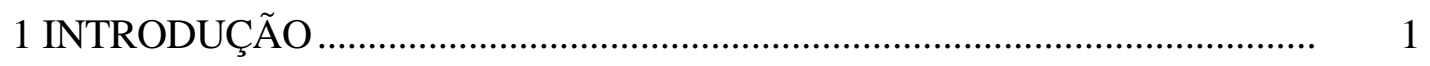

2 REVISÃO DE LITERATURA …........................................................... 4

2.1 Fontes protéicas de origem animal versus fontes protéicas de origem vegetal na alimentação de peixes ............................................................... 5

2.2 Qualidade das rações .............................................................................. 12

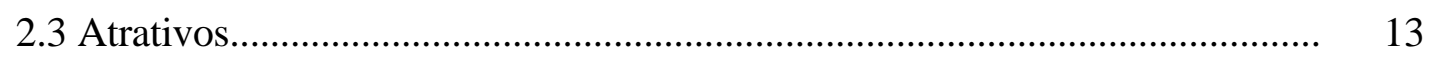

2.4 Exigências nutricionais ............................................................................. 19

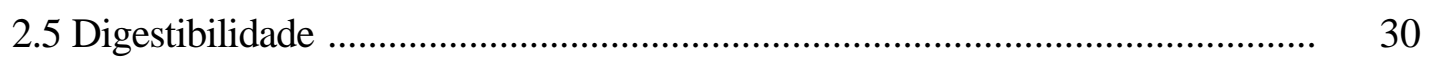

3 MATERIAL E MÉTODOS ...................................................................... 37

3.1 Experimento 1 - Atrativos em dietas à base de proteína de origem vegetal para o black bass Micropterus salmoides.............................. 38

3.2 Experimento 2 - Substituição de fontes protéicas de origem animal por fontes protéicas de origem vegetal em dietas para o black bass Micropterus salmoides.....

3.3 Experimento 3 - Digestibilidade de dietas à base de fontes protéicas de origem animal ou vegetal para o black bass Micropterus salmoides ...... 
4 RESULTADOS E DISCUSSÃO ............................................................... 49

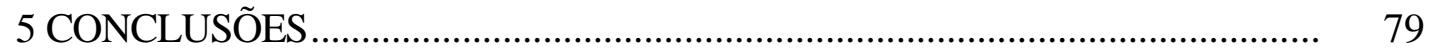

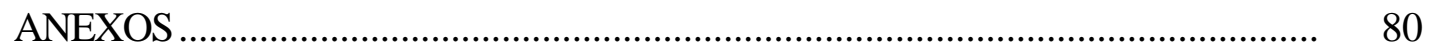

REFERÊNCIAS BIBLIOGRÁFICAS .......................................................... 86 


\section{LISTA DE FIGURAS}

Página

1 Conversão alimentar de juvenis de black bass alimentados com dietas contendo diferentes fontes e níveis de atrativos

2 Peso final de juvenis de black bass alimentados com dietas contendo diferentes fontes e níveis de atrativos

3 Ganho de peso de juvenis de black bass alimentados com detas contendo diferentes fontes e níveis de atrativos

4 Ganho de peso de juvenis de black bass alimentados com dietas contendo diferentes proporções de proteína animal e vegetal

5 Peso final de juvenis de black bass alimentados com dietas contendo diferentes proporções de proteína animal e vegetal

6 Consumo de ração de juvenis de black bass alimentados com dietas contendo diferentes proporções de proteína animal e vegetal.

7 Taxa de eficiência protéica de juvenis de black bass alimentados com dietas contendo diferentes proporções de proteína animal e vegetal.

8 Retenção protéica em juvenis de black bass alimentados com dietas contendo diferentes proporções de proteína animal e vegetal.

9 Retenção energética em juvenis de black bass alimentados com dietas contendo diferentes proporções de proteína animal e vegetal. 
10 Concentrações de glicogênio no fígado de juvenis de black bass alimentados com dietas contendo diferentes proporções de

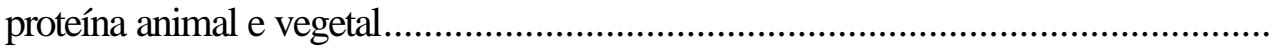

11 Concentrações de glicogênio no músculo de juvenis de black bass alimentados com dietas contendo diferentes proporções de

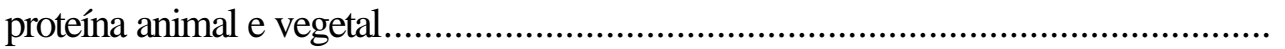

12 Relação hepatosomática de juvenis de black bass alimentados com dietas contendo diferentes proporções de proteína animal e vegetal 


\section{LISTA DE TABELAS}

Página

1 Composição nutricional dos atrativos utilizados nas dietas experimentais para juvenis de black bass. ............................................................ $\quad 30$

2 Formulação das dietas experimentais para juvenis de black bass........................... 40

3 Composição nutricional das dietas experimentais para juvenis de black bass

4 Composição corporal dos juvenis de black bass no ínicio do experimento (matéria seca)

5 Ingredientes e níveis nutricionais analisados nas dietas experimentais (matéria seca)

6 Ingredientes e níveis nutricionais analisados nas dietas experimentais (matéria seca)

7 Peso inicial (PI), peso final (PF), ganho de peso (GP), consumo de ração $(\mathrm{CR})$ e conversão alimentar $(\mathrm{CA})$ de juvenis de black bass alimentados com dietas contendo diferentes tipos e níveis de atrativos

8 Peso inicial (PI), peso final (PF), ganho de peso (GP), consumo de ração (CR) e conversão alimentar (CA) de juvenis de black bass alimentados com dietas contendo diferentes tipos e níveis de atrativos 
9 Peso inicial (PI), peso final (PF), ganho de peso (GP), consumo ração $(\mathrm{CR})$, conversão alimentar (CA), taxa de eficiência protéica (TEP), relação hepatosomática (RHS), retenção de energia (RE), retenção de proteína (RP), glicogênio no músculo (GM), glicogênio no fígado (GF), composição do fígado e da carcaça (matéria seca) de juvenis de black bass, alimentados com dietas contendo diferentes proporções de proteína animal e vegetal

10 Composição nutricional das fezes e coeficientes de digestibilidade dos nutrientes de juvenis de black bass alimentados com dietas contendo diferentes proporções de

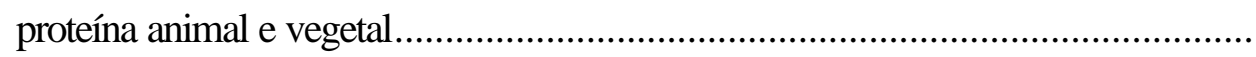




\section{LISTA DE ANEXOS}

Página

1 Disposição dos aquários, onde foi desenvolvido o Experimento 1, no Laboratório de Nutrição de Peixes da ESALQ/USP

2 Disposição das gaiolas, onde foi desenvolvido o Experimento 2, no Laboratório de Nutrição de Peixes da ESALQ/USP

3 Disposição dos aquários de digestibilidade onde foi desenvolvido o Experimento 3, no Laboratório de Nutrição de Peixes da ESALQ/USP

4 Coeficiente de digestibilidade da matéria seca para juvenis de black bass alimentados com dietas contendo diferentes proporções de proteína animal e vegetal....

5 Coeficiente de digestibilidade da proteína para juvenis de black bass alimentados com dietas contendo diferentes proporções de proteína animal e vegetal

6 Coeficiente de digestibilidade da energia para juvenis de black bass alimentados com dietas contendo diferentes proporções de proteína animal e vegetal.

7 Coeficiente de digestibilidade do extrato etéreo para juvenis de black bass alimentados com dietas contendo diferentes proporções de proteína animal e vegetal.

8 Coeficiente de digestibilidade da matéria mineral para juvenis de black bass alimentados com dietas contendo diferentes proporções de proteína animal e vegetal. 
9 Coeficiente de digestibilidade do fósforo para juvenis de black bass alimentados com dietas contendo diferentes proporções de

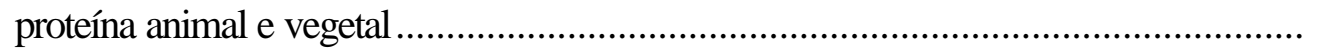




\title{
SUBSTITUIÇÃO DE FONTES PROTÉICAS DE ORIGEM ANIMAL POR FONTES PROTÉICAS DE ORIGEM VEGETAL EM RAÇÕES PARA O “BLACK BASS”' (Micropterus salmoides)
}

\author{
Autora: ANA MARIA BARRETTO DE MENEZES SAMPAIO DE OLIVEIRA \\ Orientador: PROF. DR. JOSÉ EURICO POSSEBON CYRINO
}

\section{RESUMO}

A produção comercial de peixes carnívoros exige o uso de um conjunto complexo de práticas de manejo da produção e alimentação, à redução do impacto ambiental dos alimentos e à minimização do emprego de fontes protéicas de origem animal nas formulações das dietas. O objetivo do presente estudo foi investigar o uso de atrativos alimentares em dietas formuladas exclusivamente à base de proteína de origem vegetal (PV), e seus efeitos no desempenho, composição corporal e digestibilidade das dietas pelo carnívoro "black bass", Micropterus salmoides, condicionados a aceitar ração seca. Novecentos juvenis $(26,54 \pm 1,53 \mathrm{~g})$ foram estocados em 60 aquários de polietileno de $90 \mathrm{~L}$ (15 peixes/aquário), em delineamento experimental totalmente ao acaso (n=3), e alimentados ad libitum em duas refeições diárias $(07 \mathrm{~h} 00 \mathrm{~m}$ e 17h00m), durante 13 dias, com uma dieta basal (100\% PV) contendo seis níveis de proteína solúvel de peixe - PSP $\left(0,5,1,0,1,5,2,0,2,5\right.$ e 3,0\%); Fisharom ${ }^{\circledR}$ - FA $(0,02,0,04,0,06$, 0,08, 0,10 e $0,12 \%)$; silagem de peixe - SP (1,0, 2,0, 3,0, 4,0, 5,0 e 6,0\%); um controle positivo ( $10 \%$ de farinha de peixe) e um controle negativo (dieta basal sem atrativos). Os peixes alimentados com a dieta contendo FA 0,02\% apresentaram melhor taxa de crescimento, ganho de peso e conversão alimentar, mas não apresentaram diferenças dos 
demais tratamentos $(\mathrm{P}>0,05)$. Os peixes alimentados com dietas contendo SP como atrativo apresentaram os piores resultados de desempenho. Em uma segunda etapa, foi avaliado o desempenho e a composição corporal de 560 juvenis $(3,06 \pm 0,20 \mathrm{~g})$ estocados em gaiolas de $60 \mathrm{~L}$, dentro de caixas de polietileno de $1.000 \mathrm{~L}$, instaladas em laboratório com um sistema fechado de recirculação de água com temperatura $\left(27^{\circ} \mathrm{C} \pm\right.$ $1,07^{\circ} \mathrm{C}$ ) e fotoperíodo (14L:10E) controlados, em um delineamento experimental totalmente ao acaso $(\mathrm{n}=4)$, e alimentados ad libitum em duas refeições diárias $(07 \mathrm{~h} 00 \mathrm{~m}$ e 17h00m), durante 43 dias, com 7 dietas isonitrogenadas (40\% de PB) e isocalóricas (3.500 kcal $/ \mathrm{kg}$ ), contendo níveis decrescentes de proteína de origem vegetal: 100PV:00PA; 100PV + 0,02\% Fisharon $^{\circledR} ;$ 80PV:20PA; 60PV:40PA; 40PV:60PA; 50PV:50PA (sem farinha de peixe); e uma dieta controle (ração comercial). A inclusão de farinha de peixe e farinha de penas foi limitada em 7\%; a inclusão de farinha de vísceras e farinha de carne em 15\%. DL-metionina (98\%) e L-lisina (80\%) foram adicionadas automaticamente através de matriz de aplicativo de formulação de ração. Em uma terceira etapa, foi avaliada a digestibilidade das rações utilizadas no experimento anterior. Para tanto, 1.960 juvenis $(14,0 \pm 1,0 \mathrm{~cm})$ foram confinados em gaiolas de polipropileno e alimentados durante 40 dias, no período diurno, com as sete dietas do experimento anterior acrescidas de $0,5 \%$ de óxido de cromio. No período noturno as gaiolas eram transferidas para aquários cilíndrico-cônicos de $200 \mathrm{~L}$, onde as fezes eram coletadas por sedimentação em recipiente refrigerado. $\mathrm{O}$ farelo de soja pode ser utilizado como substituto parcial de fontes protéicas e origem animal em rações formuladas para o "black bass"; a farinha de vísceras pode ser considerada uma boa opção como fonte protéica de origem animal em rações. Os melhores resultados de desempenho foram relacionados aos tratamentos controle e 50PV:50PA. A necessidade do uso da farinha de peixe na formulação de dietas para espécies carnívoras é no mínimo questionável e a determinação da digestibilidade das rações, visando maior precisão em formulações de custo mínimo para peixes carnívoros, deve ser prática corrente na indústria da alimentação de peixes. 


\title{
SUBSTITUTION OF ANIMAL PROTEIN BY PLANT PROTEIN SOURCES IN DIETS FOR THE LARGEMOUTH BASS Micropterus salmoides
}

\author{
Author: ANA MARIA BARRETTO DE MENEZES SAMPAIO DE OLIVEIRA \\ Adviser: PROF. DR. JOSÉ EURICO POSSEBON CYRINO
}

\section{SUMMARY}

Commercial farming of carnivorous fish demands the use of a complex group of practices of production and feeding management, the reduction of the environmental impact of the feeds and the minimization of the use of animal protein sources in the diets. The present study investigated the use of feed stimulants in diets formulated exclusively out of plant protein, and their effects in growth performance, body composition and digestibility of the feeds for the carnivore largemouth bass, Micropterus salmoides, conditioned to accept dry feed. Nine hundred juvenile largemouth bass $(26.54 \pm 1.53 \mathrm{~g})$ were stocked in 60 , 90 - $\mathrm{L}$ polyethylene aquaria (15 fish/aquarium), in a totally randomized experimental design $(\mathrm{n}=3)$. Fish were fed $a d$ libitum two daily meals (0700 and 1700), for 13 days, with a basal diet (100\% plant protein) containing increasing levels of fish soluble protein - FSP $(0.5,1.0,1.5,2.0,2.5$, and $3.0 \%)$; Fisharom ${ }^{\mathrm{TM}}-\mathrm{FA}(0.02,0.04,0.06,0.08,0.10$ and $0.12 \%)$; fish silage - FS $(1.0,2.0,3.0,4.0,5.0$ and 6.0\%); a positive control (10\% of fish meal) and a negative control (basal diet without stimulants). Fish fed the diet containing 0.02\%FA presented better growth rate, weight gain and feed conversion rate, but did not differ from the other treatments $(\mathrm{P}>0,05)$. Fish fed diets containing FS as stimulant presented the poorest performance. Next, the effect of different levels of dietary plant protein in the 
performance and body composition of the species was evaluated. Five hundred and sixty juvenile largemouth bass $(3.06 \pm 0.20 \mathrm{~g})$ were stocked in 60 - $\mathrm{L}$ cages, inside $1,000-\mathrm{L}$ polyethylene tanks, installed at a laboratory with closed water-recirculating system and controled temperature $\left(27^{\circ} \mathrm{C} \pm 1.07^{\circ} \mathrm{C}\right)$ and photoperiod (14L:10D). Fish were fed $a d$ libitum two daily meals (0700 and 1700), for 43 days, with 7 isonitrogenous (40\% of PB) and isoenergetic $(3,500 \mathrm{kcal} / \mathrm{kg})$ diets, containing decreasing levels of plant protein: 100PP:00AP; 100PP + 0.02\% Fisharom $\AA ;$ 80PP:20AP; 60PP:40AP; 40PP:60AP; 50PP:50AP (without fish meal); and a control diet (commercial feed). hclusion of fish meal and feathers meal was limited to $7 \%$; the inclusion of poultry by-product meal and meat and bone meal to $15 \%$. DL methionine (98\%) and L-lysine $(80 \%)$ were added automatically through feed formulation software matrix. Trial was set up in a totally randomized experimental design $(n=4)$. Finally, digestibility of the diets used in the experiment 2 was studied. One thousand, nine hundred and eighty juvenile largemouth bass $(14.0 \pm 1.0 \mathrm{~cm})$ conditioned to accept artificial, dry feed were confined in polypropilene cages and fed, for 40 days, in day time, with the seven experimental diets added of $0.5 \%$ of cromic oxide. In the night, cages were transferred to cylindricalconical bottomed, 200-L aquaria, where feces were collected by sedimentation into refrigerated containers. Data were submitted to the ANOVA and Tukey's test of comparison of means through statistical software package SAS $(\mathrm{P}=0.05)$. Soybean meal can be used as partial substitute of animal protein in diets for largemouth bass; the poultry by-product meal shows as a good option as animal protein source in these rations. Best performances were related to the control treatments and 50PP:50AP; the need for the use of fishmeal in the formulation of diets for carnivorous species is, at least, questionable. Results of the digestibility trials demonstrated the importance of determining the digestibility of the rations, if precision in the formulation of least-cost feeds for carnivorous fish is the ultimate goal. 


\section{INTRODUÇÃO}

A produção mundial de organismos aquáticos pela aqüicultura cresceu de 33.310.349 t em 1.999 para 35.585.111 t em 2.000 (FAO, 2002). No Brasil, a produção anual total de pescado cresceu de 774.750 t em 1999 para 847.268 t em 2.000 (FAO, 2002), sendo que a produção originada da aqüicultura cresceu de 119.750 t em 1999 para $153.558 \mathrm{t}$ em 2.000. A projeção da FAO relativa ao incremento da produção de organismos aquáticos através de técnicas de aqüicultura para 2010 é de 107 a 144 milhões de toneladas, das quais aproximadamente 30 milhões serão transformados em farinha de peixe e óleo para uso em produtos não alimentícios.

Em 1997 a produção mundial de peixes carnívoros estava em duas mil t/ano e representava $6 \%$ do total de produtos aquícolas produzidos no mundo. Em 1991, a produção mundial de trutas e salmões era 652.428 t, passando para 943.722 em 1995, 1.395 .739 em 1999 e 1.633 .824 t em 2000 (FAO, 2002). Este ramo da piscicultura exige a adoção de sistemas de criação manejados em regime intensivo, em que o manejo da nutrição desempenha papel importante, exigindo sério esforço de pesquisa para a geração de tecnologia adequada (FAO, 2002).

Até o final da década de 80 , a produção de peixes era realizada em regime extensivo, em pequenas propriedades rurais ou em grandes açudes, com um nível mínimo de capacitação dos produtores e de tecnificação dos meios de produção. $\mathrm{Na}$ década de 90, com o aparecimento dos pesque-pagues, a atividade apresentou um grande crescimento, caracterizado pelo aumento da demanda por peixes vivos. A partir daí, mais de 50 espécies vêm sendo produzidas comercialmente no país (Ostrensky et al., 2000), em maior ou menor escala, porém sem que praticamente nenhuma destas espécies possua uma tecnologia bem desenvolvida de produção em escala industrial. 
A criação de peixes carnívoros no Brasil foi iniciada a mais de 40 anos com a introdução da truta arco-íris (Azevedo et al., 1961). Durante a década de 90, outras espécies nativas de hábito alimentar carnívoro passaram a ser exploradas, como o dourado Salminus maxillosus, o pintado ou surubim Pseudoplatystoma coruscans, o pirarucu Arapaima gigas e o tucunaré Cichla sp., todas muito valorizadas tanto como peixes de mesa como para pesca esportiva. Faz-se então necessário determinar as exigências nutricionais destas espécies, principalmente os teores de proteína e energia das rações, visando a formulação de rações para produção comercial destas espécies, todas produzidas exclusivamente a partir de alimentos nutricionalmente completos em regime intensivo, onde os gastos com alimentos compreendem 50 a $70 \%$ dos custos de produção (Lovell, 1989).

A alimentação animal é um importante elo da agroindústria brasileira. $\mathrm{O}$ setor consome cerca de $65 \%$ da produção nacional de milho e $45 \%$ da oferta de farelo de soja, constituindo-se assim em um dos principais clientes da produção agrícola nacional, além de movimentar a indústria química para o fornecimento de insumos, como vitaminas, aminoácidos e microingredientes para nutrição animal. É também um importante pólo de desenvolvimento tecnológico, voltado à produção de proteína animal, destinada à alimentação humana, pois está na base da produção de carnes, ovos e leite. Em 2001 a indústria de alimentação animal movimentou 38,8 milhões de toneladas de grãos, que representaram cerca de US\$ 7,0 bilhões, gerando em torno de 65.000 empregos diretos (Bútolo, 2002).

Existe uma quantidade apreciável de resultados de pesquisas criteriosas feitas sobre exigências nutricionais das espécies de peixes nacionais. Falhas no sistema de divulgação destes estudos condicionam uma extrapolação de dados por parte dos fabricantes de rações, principalmente no que diz respeito à manufatura de alimentos para atividades de terminação de peixes. Por isso, o conhecimento da nutrição das espécies se torna essencial ao estabelecimento da piscicultura comercial no país, permitindo obter o melhor rendimento de cada espécie em criação.

As pesquisas sobre alimentação e nutrição de peixes carnívoros, especialmente nas universidades e institutos de pesquisa da América do Norte e Europa, são centradas 
em trabalhos com Centrarchideos, espécies consideradas modelos para aplicação e aprimoramento de novas técnicas, avaliação da qualidade nutricional de ingredientes e avaliação do potencial produtivo de espécies carnívoras. Foi então desenvolvido o presente estudo com o "black bass", Micropterus salmoides Lacepède, 1802 (Actinopterygii: Perciformes: Centrarchidae) com o objetivo de avaliar o efeito da substituição da fonte protéica de origem animal por fontes protéicas de origem vegetal com uso de palatabilizantes no desempenho e composição corporal, visando contribuir com novos conhecimentos que possibilitem a diminuição do custo no preparo de rações comerciais para produção intensiva de espécies carnívoras.

Os resultados do presente projeto podem trazer muitos benefícios para os produtores das regiões Sul e Sudeste, que apresentam temperaturas mais amenas durante o ano. Os piscicultores destas regiões poderiam passar a aplicar as técnicas de adequação alimentar propostas nos estudos nutricionais desta e demais espécies de peixes esportivos carnívoros, viabilizando sua produção e utilização em larga escala na indústria da pesca esportiva. O refinamento das estratégias de produção desta espécie de grande valor de mercado poderá abrir novas perspectivas à emergente indústria da aqüicultura brasileira. 


\section{REVISÃO DE LITERATURA}

O "largemouth bass" Micropterus salmoides foi introduzido no Estado de Minas Gerais em 1924 (Godoy, 1954) e disseminou-se rapidamente pelas regiões de clima ameno do Rio de Janeiro, São Paulo e toda região Sul do país, onde é manejado extensivamente como peixe esportivo e conhecido como black bass. É uma espécie originária dos lagos e riachos da América do Norte, podendo ser encontrada no México e em alguns países da Europa. Dados apresentados por Venturieri (2002) mostram que a indústria da pesca esportiva tem movimentado, anualmente, valores brutos ao redor de R\$ 500 milhões somente no Estado de São Paulo.

Porém, como a pressão de pesca é grande e ainda existem praticantes da pesca esportiva que preferem matar as espécies a liberá-las após captura, a população de black bass nos açudes e águas públicas vem decrescendo. Tal fato demonstra a importância da criação desta espécie em confinamento e, conseqüentemente, da necessidade de melhores conhecimentos sobre seu manejo alimentar e nutrição, o que permitirá sua criação em sistemas manejados intensivamente com o uso de rações completas, a exemplo do que já ocorre na América do Norte, onde a produção intensiva de juvenis avançados de black bass alimentados com ração comercial seca em viveiros sem renovação de água e com aeração de emergência resulta em índices de produtividade de até $7.200 \mathrm{~kg} / \mathrm{ha}$ em 117 a 153 dias de cultivo, com conversão alimentar de 0,97 a 1,14 (Kubitza, 1995; Kubitza \& Lovshin, 1997). 


\subsection{Fontes protéicas de origem animal versus fontes protéicas de origem vegetal na alimentação de peixes}

O uso de fontes de proteína animal ou vegetal mais baratas para substituir a farinha de peixe, um ingrediente que contém proteína de alta qualidade e boa palatabilidade e o mais caro de todos os ingredientes utilizados na indústria da alimentação animal é uma área importante da pesquisa em nutrição de peixes (Webster et al., 2000). Segundo Francis et al. (2001), a substituição da farinha de peixe por fontes alternativas de proteína nas rações foi fortemente recomendada no Segundo Simpósio Internacional de Aqüicultura Sustentável realizado em Oslo, Noruega, em 1998. De um modo geral, os ingredientes de origem animal melhoram o valor nutritivo da dieta, por seu balanço em aminoácidos, minerais, vitaminas do complexo $\mathrm{B}$ e por suas características sensoriais. Segundo Pezzato (2002), os produtos de origem animal promovem um maior crescimento dos peixes e, portanto as dietas de máxima eficiência necessitam da presença destes ingredientes como fonte protéica fundamental. No entanto, o resultado desta prática é o alto custo da dieta e do peixe produzido. Pezzato (1995) considera a farinha de peixe um alimento padrão na composição das dietas em função do seu elevado valor biológico: equilíbrio nos níveis de aminoácidos, cálcio, fósforo e vitaminas lipo e hidrossolúveis.

Avaliando o efeito da qualidade da farinha de peixe e do processamento da ração no desempenho do "seabream", Aksnes et al. (1997) encontraram que os valores de digestibilidade não variaram entre as dietas extrusadas produzidas com farinha de peixe de qualidade variada. Porém, a digestibilidade da proteína, foi 7\% maior em dietas extrusadas quando comparadas às dietas pelletizadas. Esta diferença não pode ter sido causada por diferença na eficiência alimentar ou taxa de crescimento, pois não houve diferença para estes parâmetros. Os peixes que receberam dietas pelletizadas, entretanto, apresentaram menos lipídio muscular, apesar do maior conteúdo deste nutriente na dieta, o que, por sua vez, pode ter sido compensado pela menor digestibilidade.

A farinha de vísceras é considerada uma boa alternativa para a farinha de peixe em rações para peixes carnívoros, mas é freqüentemente considerada deficiente em um 
ou mais aminoácidos essenciais. A suplementação das dietas com aminoácidos sintéticos, e.g. lisina e metionina, permite produzir rações isentas de farinha de peixe e baseadas exclusivamente em farinha de vísceras, para a truta arco-íris Onchorhynchus mykiss (Nengas et al., 1999).

Bureau et al. (2000) testaram farinha de vísceras e de carne e ossos de diferentes procedências na alimentação da truta arco-íris e concluíram que a substituição de $15 \%$ de farinha de peixes pela farinha de vísceras na dieta não afeta o crescimento, eficiência alimentar e função osmorregulatória dos peixes. A redução no ritmo de crescimento de peixes alimentados com dieta contendo $20 \%$ de farinha de vísceras pode ser atribuída à deficiência em lisina ou outros aminoácidos. Segundo Fowler (1991), a farinha de vísceras pode substituir a farinha de peixe em dietas para o salmão do Pacífico ou "Chinook" Oncorhynchus tshawytscha em níveis de até 20\%. Entretanto, níveis de $30 \%$ da dieta reduzem o crescimento provavelmente devido à redução da palatabilidade e, conseqüentemente, ingestão (Webster et al., 2000).

A farinha de carne pode apresentar alto conteúdo de cinzas, o que pode reduzir a estabilidade física dos grânulos de rações que tenham farinha de carne na sua composição e a disponibilidade dos nutrientes presentes no ingrediente. Além disso, apresenta menores quantidades de lisina, metionina mais cistina e treonina. Entretanto, Stone et al. (2000) realizaram experimentos para avaliar a substituição da farinha de peixe pela farinha de carne em dietas para a perca australiana e observaram que os nutrientes e energia foram bem digeridos quando as dietas continham até $30 \%$ deste ingrediente. Monhsen \& Lovell (1990) citam que a inclusão da farinha de carne e ossos em níveis de até $11 \%$ aumenta a palatabilidade de dietas contendo farelo de soja e milho para o bagre do canal.

Vários ingredientes alternativos de origem vegetal são conhecidos por conter uma ampla variedade de substâncias antinutricionais. Antinutrientes são substâncias que, através delas próprias ou através da formação de derivados, interferem na utilização de alimentos, afetando a saúde e a produção dos animais. Os antinutrientes podem ser divididos em quatro grupos: (1) fatores que afetam a utilização de proteína e digestão, e.g. inibidores de protease, taninos e lecitinas; (2) fatores que afetam a utilização de 
minerais, e.g. fitatos, gossipol, oxalatos, glucosinolatos; (3) antivitaminas; (4) variados, como as micotoxinas, alcalóides, saponinas, nitratos, fitoestrogênios, etc. Antinutrientes também podem ser classificados de acordo com a habilidade de resistir a processos térmicos, o tratamento mais utilizado para destruí-los. Antinutrientes termolábeis incluem inibidores de protease, fitatos, lecitinas, tireotoxinas e antivitaminas, ao passo que os estáveis ao calor são representados pelas saponinas, polissacarídeos não amiláceos, proteínas antigênicas, estrogêneos e alguns compostos fenólicos. Embora oligossacarídeos tornem-se mais digestíveis após tratamentos sob altas temperaturas, a eficiência deste tratamento para substâncias como o tanino, é incerta (Francis et al., 2001).

O glúten de milho apresenta alto nível de proteína, pouca fibra, é rica em vitaminas B e E e conhecida por não apresentar fatores antinutricionais. Entretanto, é deficiente em lisina. Regost et al. (1999) observaram que o "turbot" Psetta maxima alimentado com dietas contendo glúten de milho em substituição à farinha de peixe, apresenta menor digestibilidade da proteína, fato atribuído à qualidade do ingrediente e/ou ao método de coleta das fezes, pois a proteína do glúten de milho é considerada de boa digestibilidade (National Research Council, 1993). Foi observada também uma diminuição na digestibilidade aparente dos aminoácidos e redução no crescimento, conforme a inclusão de glúten de milho aumentou de 20 para $57 \%$ na dieta. Pesquisas na área de substituição da farinha de peixe, utilizando combinações de diferentes fontes de proteína, têm sido relatadas como a melhor alternativa. A inclusão de altos níveis de uma determinada fonte de proteína de origem vegetal pode exacerbar problemas, não só relacionados ao balanço de aminoácidos essenciais, mas também relacionados aos possíveis efeitos dos fatores antinutricionais (Watanabe et al., 1997).

Segundo Forsythe (1995) as fontes de proteína de origem vegetal afetam o metabolismo de ambos, colesterol e tiróide. De acordo com Riley et al. (1993), os hormônios tireoidianos são bons marcadores biológicos da capacidade de crescimento dos peixes. Baixas concentrações plasmáticas de triiodotironina $\left(T_{3}\right)$, hormônio biologicamente ativo, são indicativos de problemas metabólicos expressos como baixo crescimento. 
Poston (1965) determinou que a concentração de aminoácidos no sangue de trutas alimentadas com farelo de soja era igual à de trutas alimentadas com farinha de peixe. A diferença da digestibilidade da fração protéica do farelo de soja e da farinha de peixe não foi suficiente para explicar a diferença de crescimento dos peixes. Pezzato (2002) relata alguns estudos que têm demonstrado melhora no crescimento de peixes, mesmo de carnívoros, com dietas a base de farelo de soja, utilizando suplementação com os aminoácidos metionina, leucina, lisina, valina, treonina e triptofano.

A soja apresenta baixos níveis de fósforo e zinco e apenas $0,6 \%$ do fósforo mostra-se disponível, como consequiência da presença do ácido fítico. Miranda et al. (2000), trabalhando com alevinos de tilápia do Nilo (16,0 g), avaliaram a disponiblidade aparente do fósforo de seis ingredientes alimentares: fosfato bicálcico, farinha de ossos, farinha de peixes, farelo de soja, farelo de trigo e fubá de milho. O fosfato bicálcico foi considerado a fonte preferencial de fósforo nas rações, com disponibilidade aparente de $74,2 \%$. Segundo Pezzato (2002), o sorgo baixo tanino (Sorghum vulgare) tem se apresentado como ótima fonte energética e para a tilápia do Nilo apresenta coeficientes de digestibilidade aparente semelhantes aos do milho (Freire et al., 2002).

O farelo de soja tem sido utilizado para várias espécies com relativo sucesso apesar de ser pouco palatável e apresentar um perfil de aminoácidos pouco adequado (McGoogan \& Gatlin, 1997). Mohsen \& Lovell (1990) relataram que o bagre do canal Ictalurus punctatus, por exemplo, apresentou um aumento no ganho de peso conforme aumentou a proporção da mistura farelo de soja-milho na dieta. Entretanto, Reigh \& Ellis (1992) observaram que "red drum" Sciaenops ocellatus, com 7,4 g de peso inicial, apresentaram ganho de peso reduzido quando alimentados com dieta à base de farelo de soja, contendo menos que $25 \%$ da proteína originária da farinha de peixe. Na mesma linha de pesquisa, Davis et al. (1995) encontraram para o "red drum", com peso inicial de $0,4 \mathrm{~g}$, um decréscimo no ganho de peso quando a quantidade de farinha de peixe diminuiu de 60 para $45 \%$ da dieta, substituída por quantidade equivalente da proteína pelo farelo de soja. $\mathrm{O}$ crescimento dos alevinos foi prejudicado por uma deficiência de aminoácidos sulfurosos, pois quando metionina foi adicionada à dieta, foi observado um aumento no crescimento. Davis et al. (1995) também sugerem que a adição de atrativos 
às rações que contenham altos níveis de farelo de soja, pode aumentar o ganho de peso de espécies carnívoras.

A substituição da proteína da farinha de peixe pela proteína do farelo de soja em dietas para o "gilthead seabream" Sparus auratus, reduziu a atividade da tripsina e o coeficiente de digestibilidade da proteína conforme aumentou o nível de substituição da proteína de 10 para 30\%. Segundo Robaina et al. (1995), estes resultados estão associados à presença de fitatos, que são indisponíveis para a maioria dos peixes, devido à ausência da enzima fitase no seu trato digestivo. O ácido fítico causou redução da digestibilidade da proteína em truta arco-íris (Spinelli et al., 1983), como também reduziu a disponibilidade de $\mathrm{Zn}$ em salmonídeos (Richardson et al., 1985) e em bagre do canal (Satoh et al., 1989). Como o farelo de soja apresenta $75 \%$ de fósforo na forma de ácido fítico, é possível que a disponibilidade do fósforo diminua com o aumento da inclusão de farelo de soja na dieta.

Robaina et al. (1995) observaram aumento na deposição de lipídio no fígado associado à diminuição de glicogênio em peixes alimentados com farelo de soja. Neste mesmo experimento os autores avaliaram a produção de amônia e observaram que o pico de excreção de amônia ocorreu 4,0 a 4,5 h após a alimentação, e sugeriram que os peixes alimentados com dietas contendo fontes de proteína de origem vegetal exigem um tempo maior para digestão, absorção e metabolismo da proteína. O total de amônia dissolvida excretada, calculada de valores obtidos durante um período de 8 horas, foi $40 \%$ maior em peixes alimentados com dietas contendo 30\% da proteína do farelo de soja. Este fato justifica a menor deposição de proteína nos peixes alimentados com proteína de origem animal.

Segundo Tacon \& Jackson (1985), a substituição de $40 \%$ ou mais da proteína da farinha de peixe de alta qualidade em dietas para a truta arco-íris, normalmente causa redução no crescimento. Esta redução é atribuída à ocorrência de antinutrientes nos farelos de soja. As farinhas de peixes são aceitas por serem palatáveis para a maioria das espécies de peixes, portanto a sua substituição pelo farelo de soja pode reduzir o conteúdo de atrativos nas dietas de trutas. De fato, Refstie et al. (1997) avaliaram a 
adaptação da truta arco-íris ao farelo de soja e os observaram que os peixes se adaptaram bem a dietas contendo $67 \%$ da proteína como farelo de soja.

Webster et al. (1995) mostraram que o "blue catfish" Ictalurus furcatus apresenta bom desenvolvimento consumindo rações contendo basicamente farelo de soja como fonte de proteína. Estudos similares com truta arco-íris, "yellowtail" Seriola quinqueradiata e "red drum" mostraram que o farelo de soja é uma fonte de proteína viável para peixes carnívoros (McGoogan \& Gatlin, 1997). Em experimento utilizando farelo de soja como substituto para a farinha de peixe em rações para o "Japanese flounder" Paralichthys olivaceous, Kikuchi (1999) mostrou que a inclusão de 25\% de farelo de soja em combinação com a farinha de sangue ou farelo de glúten de milho e mexilhão azul como atrativo promoveu bom crescimento e conversão alimentar relacionados ao aumento do consumo de alimento pelos peixes.

A resposta à substituição da farinha de peixe pelo farelo de soja varia com a espécie de peixe. Refstie et al. (2000) observaram que dietas contendo farinha de peixe e $30 \%$ de farelo de soja reduziram a absorção e retenção de nutrientes em truta arco-íris e salmão do Atlântico em comparação a dietas contendo somente farinha de peixe como fonte protéica. A absorção intestinal de nitrogênio e de gordura foi maior para a truta, ao passo que a utilização e absorção de nitrogênio e energia para crescimento foi mais eficiente nos salmões. A truta pareceu menos sensível aos fatores antinutricionais do que o salmão e, consequientemente, apresentou a mesma taxa de crescimento quando alimentadas com a dieta contendo $30 \%$ de farelo de soja e com a dieta contendo somente farinha de peixe.

Pezzato (1995) relata que as fontes protéicas de origem vegetal são de qualidade inferior às de origem animal, apresentam menor digestibilidade, são deficientes em metionina e lisina, e apresentam alguns fatores antinutricionais. Entretanto, são uma opção mais econômica para confecção de dietas. Relata ainda que o farelo de soja, subproduto resultante da extração do óleo do grão da soja Glycine max (L.), é a fonte protéica vegetal mais estudada para peixes. Apresenta razoável balanço de aminoácidos e pode substituir em até 50\% a farinha de peixe em dietas para trutas e $94 \%$ para espécies onívoras. 
Em experimentos realizados por Cyrino et al. (1986) com o matrinxã Brycon cephalus, não foram encontradas diferenças significativas na digestibilidade da fração protéica de cinco rações isoprotéicas (35\% PB) e isoenergéticas 3.000 (kcal ED/kg), quando a proteína da farinha de peixe foi substituída pelo farelo de soja em níveis de 0 a $80 \%$. O potencial de emprego de proteína vegetal na alimentação de peixes tropicais foi ainda demonstrado por Mendonça et al. (1993), quando alimentaram matrinxãs com dietas (25\% PB) contendo $45,7 \%$ de farelo de soja ou 31,4\% de farinha de peixe e obtiveram, respectivamente, pesos finais de $1,343 \mathrm{~kg}$ e $1,149 \mathrm{~kg}$, com conversão alimentar de 1,9 e 2,3. Concentrado de proteína de soja foi utilizado em dietas para o "halibut" do Atlântico Hippoglossus hippoglossus pesando 600 a 900 g. A substituição de $45 \%$ da proteína da farinha de peixe pelo concentrado de proteína de soja suplementado com metionina não reduziu a taxa de crescimento e não afetou negativamente a conversão alimentar dos peixes (Berge et al., 1999).

Robaima et al. (1999) avaliaram a excreção da amônia em "sea bass" Dicentrarchus labrax alimentados com dietas pelletizadas ou extrusadas, com ou sem glúten de trigo. Como estes ingredientes são deficientes em um ou mais aminoácidos essenciais, é necessário saber como o catabolismo dos aminoácidos é afetado em peixes alimentados com fontes de proteína de origem vegetal. Os coeficientes de digestibilidade medidos não foram afetados pelo método de processamento das dietas e pela inclusão do glúten de trigo em substituição à farinha de peixe. A tecnologia da extrusão é conhecida por aumentar a gelatinização e melhorar a disponibilidade do amido para peixes de água doce e marinhos. As taxas de excreção da amônia aumentaram rapidamente após alimentação, apresentando valores máximos após 8 horas para todos os tratamentos. As maiores taxas de excreção para peixes alimentados com dietas contendo glúten de trigo foram relacionadas aos maiores níveis de proteína nas dietas, pois foi estabelecida uma relação linear entre o nitrogênio ingerido e o nitrogênio excretado. Além disso, o excesso de alguns aminoácidos, como o ácido glutâmico (originado do glúten de trigo), pode ter contribuído para o aumento da excreção da amônia e aumento da atividade da enzima glutamato desidrogenase no fígado de peixes alimentados com dietas formuladas à base de ingredientes de origem vegetal, ricos em ácido glutâmico. A taxa de excreção 
de amônia dos peixes alimentados com dietas extrusadas, foi menor que aqueles alimentados com dietas pelletizadas. A possível explicação, é que a extrusão aumenta a disponibilidade do amido e conseqüentemente a utilização do nitrogênio. Aksnes et al. (1997) também mostraram que a extrusão pode melhorar o valor biológico de algumas farinhas de peixe.

Robaima et al. (1999) mostraram que o consumo de alimento pelos peixes induz uma hiperglicemia transitória, que desaparece após $24 \mathrm{~h}$. A baixa utilização de glicose em peixes, relacionada à inabilidade de controlar a concentração de glicose no sangue, foi primeiramente atribuída à baixa secreção de insulina. De qualquer modo, alguns trabalhos têm mostrado claramente que a maioria dos peixes secreta insulina, mas não apresenta capacidade de fosforilação da glucose (Wilson, 1994).

\subsection{Qualidade das rações}

As rações para peixes são produzidas a partir de uma mistura de ingredientes, em diferentes proporções, e balanceadas para atender as exigências nutricionais. As rações extrusadas são as mais aceitas comercialmente. O processo de extrusão confere maior digestibilidade aos nutrientes porque gelatiniza $\mathrm{o}$ amido, desativa fatores antinutricionais termolábeis e destrói a maioria dos microorganismos nocivos aos peixes (fungos e bactérias). Além disso, este tipo de processamento melhora estabilidade na água e confere flutuabilidade ao alimento, o que permite observar o comportamento alimentar dos peixes, traduzido em maior eficiência alimentar e produtiva (Lovell, 1989; Pezzato, 2002).

O objetivo principal da formulação de rações é fornecer aos animais uma mistura de ingredientes nutricionalmente balanceada que permita desempenho e higidez do estoque a um custo aceitável. Além disso, a formulação deve facilitar o processamento, de forma que a ração apresente características físicas apropriadas. A dieta deve ser palatável e não deve conter componentes antinutricionais que possam impedir o desenvolvimento do animal. A palatabilidade da dieta deve ser compatível 
com as exigências de cada espécie e afetar o mínimo possível a qualidade da água do sistema (NRC, 1993).

O processo de extrusão envolve a combinação de diferentes condições físicas (temperaturas entre 130 a $150^{\circ} \mathrm{C}$; pressão entre 30 e $60 \mathrm{~atm}$ ) e estratégias de formulações das rações no processo de produção. Conseqüentemente, as rações extrusadas apresentam baixa quantidade de finos, reduzida velocidade de sedimentação e alta estabilidade na água (Kearns, 1989, 1999; Millauer \& Losenegger, 1999). Todos estes fatores são de extrema importância para as espécies carnívoras, pois estas são mais vorazes e apresentam forte influência do efeito de grupo no comportamento alimentar, o que condiciona a apreensão dos grânulos oferecidos na superfície, desprezando todo e qualquer alimento que por algum motivo possa submergir e ficar no fundo do ambiente (Kubitza et al., 1997).

\subsection{Atrativos}

As rações utilizadas para peixes carnívoros contêm, geralmente, altos níveis de proteína animal, farinha de peixe em particular. Estas rações, por sua vez, não apresentam somente alto custo, mas contribuem para eutrofização das águas, porque condicionam excreção de altos níveis de fósforo pelos peixes. Em adição, os estoques de farinha de peixe apresentam tendência de queda, ou pelo menos de estabilidade da oferta, enquanto a produção aquícola está aumentando constantemente (FAO, 1999; 2002).

Adicionar atrativos às dietas pode aumentar a aceitabilidade de rações artificiais por larvas e alevinos, aumentar o consumo de rações de baixa palatabilidade, com conseqüente aumento na taxa de crescimento e atrair os peixes na pesca comercial e esportiva. Além disso, o uso de atrativos para aumentar a palatabilidade de rações comerciais pode resultar em um aumento do consumo com conseqüente redução no tempo de alimentação e redução de sobras de alimento na água.

Com o objetivo de identificar alguns atrativos mais comumente encontrados nos peixes e eleger a mistura mais efetiva destas substâncias para o "striped bass" Morone 
saxatilis, Papatryphon \& Soares Jr. (2000a) realizaram uma série de ensaios, e observarm que os aminoácidos neutros não essenciais - alanina, serina, glicina e prolina - são os mais efetivos. Somente alanina e serina apresentaram resposta significativa quando testados individualmente. Na sequiência, outras substâncias foram testadas individualmente e os resultados mostraram, novamente, que a alanina (aminoácido neutro) foi a mais efetiva, seguida por inosina monofosfato (nucleotídeo), serina (aminoácido neutro) e betaína (amônia quaternária). A adenosina apresentou efeito negativo, que aumentou com o aumento do grupamento fosfato; o ácido cítrico também reduziu o consumo de alimento pelo "striped bass", porém não significativamente; a suplementação de $2 \%$ de solúveis de peixes resultou em significativo aumento do consumo de alimento, aproximando-se do efeito dos aminoácidos neutros não essenciais.

Solúveis de peixes têm sido utilizados para peixes carnívoros como atrativos com sucesso variável. A suplementação de $2 \%$ em rações formuladas a base de farinha de peixe para o "red drum" não apresentou efeito benéfico no desenvolvimento (Davis et al., 1995). Por outro lado, 2 a 4\% de suplementação aumentou o consumo de alimento do "red drum" alimentado com ração formulada à base de farelo de soja (McGoogan \& Gatlin, 1997).

Papatryphon \& Soares Jr. (2000b) testaram também o efeito de atrativos no crescimento de "striped bass" alimentados com dietas à base de ingredientes de origem vegetal: basal; $2 \%$ de uma mistura de atrativos $(2,71 \mathrm{~g}$ de alanina $+3,20 \mathrm{~g}$ de serina + 10,53 g de inosina 5-monofosfato + 3,56 g de betaína/kg de ração); e 4\% de outra mistura de atrativos $(5,42 \mathrm{~g}$ de alanina $+6,40 \mathrm{~g}$ de serina $+21,06 \mathrm{~g}$ de inosina 5monofosfato $+7,12 \mathrm{~g}$ de betaína/kg de ração). A suplementação das dietas com atrativos melhorou o desenvolvimento do "striped bass", mas não houve diferença entre os níveis de suplementação para a variável conversão alimentar. Entretanto, o nível de $4 \%$ de suplementação aumentou o consumo de alimento e, conseqüentemente, o ganho de peso.

O aumento na palatabilidade da ração resulta em melhor utilização do alimento como resposta ao reflexo cefálico (Giduck et al., 1987). De fato, Takii et al. (1986) observaram significativos aumentos da atividade de enzimas hepáticas e digestivas em 
enguias alimentadas com rações suplementadas com atrativos, em comparação a peixes alimentados com rações não suplementadas.

Nesta mesma linha de pesquisa, Papatryphon \& Soares Jr. (2001) testaram também os ńveis dos atrativos em dietas contendo farinha de peixe e farelo de soja, que resultaram em melhor desempenho para o "striped bass". Num primeiro experimento foram utilizadas duas dietas basais, contendo farinha de peixe e ingredientes de origem vegetal. Cada dieta recebeu uma mistura de atrativos $(0,4 \%$ de alanina $+0,6 \%$ de serina $+0,2 \%$ de inosina 5-monofosfato $+0,4 \%$ de betaína) nas concentrações de $0,1,7 \%$, $3,4 \%$ e $6,8 \%$ da dieta. Num segundo experimento, foram preparadas quatro dietas: duas à base de farinha de peixe sem e com suplementação com 3,4\% da mistura do atrativo; duas à base de ingredientes de origem vegetal sem e com a suplementação com 3,4\% de mistura do atrativo. No primeiro experimento, o melhor nível de suplementação do atrativo corresponde a $1,7 \%$ da dieta, considerando que não houve diferença entre os níveis. A inclusão da mistura de atrativos na dieta condicionou aumentos similares no consumo de alimento por "striped bass" alimentados tanto com dietas à base de farinha de peixe como à base de ingredientes de origem vegetal, nos primeiros seis dias de alimentação. Além disso, a diferença no consumo de alimento entre os peixes que receberam as dietas com farinha de peixe e ingredientes vegetais pode ser eliminada com a suplementação da mistura de atrativos na dieta vegetal; suplementar as dietas com a mistura de atrativos pode aumentar o consumo pelos peixes alimentados com dietas à base de farinha de peixe. No segundo experimento, o melhor desempenho foi obtido dos peixes que receberam a dieta contendo farinha de peixe mais a suplementação com a mistura de atrativos, seguido da dieta contendo somente farinha de peixe, contendo ingredientes vegetais mais a suplementação e, por último, aqueles que receberam a dieta contendo somente os ingredientes vegetais. A viabilidade financeira do uso ou não de atrativos ainda é questionável, mas isto pode vir a ser uma necessidade em um futuro próximo, especialmente no caso da substituição total da farinha de peixe nas rações em resposta a considerações e restrições ecológicas (Papatryphon \& Soares Jr., 2001).

Carr (1982) determinou que substâncias utilizadas para estimular o consumo de alimento em peixes devem reunir quatro características: apresentar baixo peso 
molecular; conter nitrogênio; não ser volátil e solúvel em água; e apresentar propriedades ácidas e básicas. Já foi também demonstrado que as espécies carnívoras são mais atraídas por substâncias alcalinas e neutras, como glicina, prolina, valina e betaína, enquanto peixes herbívoros respondem melhor a substâncias ácidas, como os ácidos aspártico e glutâmico (NRC, 1993). A glicina, por exemplo, é um nutriente que atende a estas características e foi demonstrado ser atrativa para várias espécies, como para o "sea bream" (Fuke et al., 1981; Shimizu et al., 1990) e para o salmão "Chinook" (Hughes, 1985).

L-aminoácidos, particularmente os aminoácidos neutros, são substâncias mediadoras da resposta alimentar dos peixes e bases nitrogenadas orgânicas e nucleotídeos estão envolvidos no mecanismo de resposta alimentar dos peixes (Hughes, 1991; Kubitza, 1995). Resultados de investigações sobre o uso de substâncias que estimulam o consumo de alimento pelos peixes, sugerem que embora o sabor de um alimento seja quimicamente mediado por substâncias inerentes ao alimento, depende ainda da quimiossensitividade da espécie (Adams et al., 1988). Desta forma, misturas são mais eficazes para estimular a resposta alimentar dos peixes que componentes individuais (Kubitza, 1995).

Em estudos com o "largemouth bass" Micropterus salmoides, Kubitza et al. (1997) testaram o efeito da substituição da farinha de peixe pelo farelo de soja (60 \%) na palatabilidade das dietas, adicionando às rações uma mistura de aminoácidos (2.000mg de alanina $+3.836 \mathrm{mg}$ de glicina $+305 \mathrm{mg}$ de prolina $+1.205 \mathrm{mg}$ de serina $+614 \mathrm{mg}$ de leucina $+800 \mathrm{mg}$ de valina $+273 \mathrm{mg}$ de histidina $+318 \mathrm{mg}$ de triptofano por $\mathrm{kg}$ de dieta), nucleotídeos $(2.800 \mathrm{mg}$ de inosina $+2.800 \mathrm{mg}$ de inosina-5-monofosfato por $\mathrm{kg}$ de dieta) e betaína $(6.100 \mathrm{mg} / \mathrm{kg})$. Foram elaboradas 7 rações experimentais: ração controle contendo $60 \%$ de farelo de soja; apenas com aminoácidos; apenas com a betaína; apenas com os nucleotídeos; com aminoácidos mais betaína; aminoácidos mais nucleotídeos; com betaína mais nucleotídeos; e com os aminoácidos mais betaína mais nucleotídeos. Baseando-se no consumo diário de ração, os melhores resultados foram relativos às rações contendo somente nucleotídeos. 
Kubitza et al. (1997) realizaram outro experimento com a mesma espécie, testando somente os nucleotídeos, inosina e inosina monofosfato, juntos ou isoladamente, em diferentes níveis. Apesar de estarem associados a um aumento na resposta alimentar dos peixes, os aminoácidos neutros não estimularam o consumo de alimento. A betaína, composto orgânico encontrado em grandes concentrações em extratos de crustáceos e considerado um bom atrativo do consumo de alimento para peixes, também não foi efetivo neste estudo. O IMP-5', encontrado em abundância em músculos de peixes e, consequientemente, na farinha de peixe, foi o nutriente que apresentou melhor efeito estimulatório no consumo de alimento.

Segundo McGoogan \& Reigh (1996), o "red drum" foi capaz de utilizar dietas com até $80 \%$ da proteína originária do farelo de soja e $20 \%$ da farinha de peixe sem redução significativa no ganho de peso quando comparado a dieta contendo toda proteína originária da farinha de peixe. A suplementação com glicina mostrou favorecer o ganho de peso de peixes alimentados com dieta contendo predominantemente farelo de soja.

A silagem de peixe é um produto liquefeito obtido por ação de enzimas naturalmente presentes no peixe inteiro, partes não aproveitadas e resíduos de processamento, na presença de ácidos que previnem a deterioração microbiana. Existem basicamente dois métodos principais para a produção de silagem: o método químico, em que são adicionados ácidos orgânicos e/ou inorgânicos aos resíduos de pescado e o método de fermentação, no qual se adicionam bactérias láticas, produtoras de ácido lático. Em ambos os métodos, a presença do ácido diminui o $\mathrm{pH}$ da massa triturada, deixando livre a ação das enzimas naturalmente presentes nos tecidos dos peixes (Viégas, 2002; Arruda et al., 2001).

O valor nutritivo da silagem está na sua digestibilidade protéica, que deve ser preservada, evitando-se uma estocagem prolongada. Em comparação à farinha de peixe, a silagem apresenta teores mais baixos de aminoácidos sulfurados, porém mais elevados em lisina (Arruda et al., 2001).

As rações utilizadas para peixes carnívoros atualmente, são dependentes da farinha de peixe, como a principal fonte de proteína e lipídio. A proteína hidrolisada de 
peixe é um ingrediente potencial utilizado em rações, principalmente como, suplemento protéico e atrativo. O uso da proteína hidrolisada de peixe produzida pelo préprocessamento do material cru com enzimas hidrolíticas e posterior aquecimento em rações têm mostrado aumento no crescimento e utilização de alimento em salmonídeos (Berge \& Storebakken, 1996; Carvalho et al., 1997). Este efeito positivo pode ser atribuído ao aumento da digestiblidade da proteína devido ao tratamento enzimático, o qual inicia a degradação das proteínas. A degradação das proteínas fornece peptídeos de cadeia curta e aminoácidos livres.

Aminoácidos livres resultantes do processo podem também funcionar como atrativos para algumas espécies, aumentando crescimento e utilização de alimento. Entretanto, aminoácidos livres mostraram ter menor efeito como atrativo para o "turbot". Testando a utilização de altos níveis de proteína hidrolisada $(5,15$ e $25 \%)$ para juvenis de "turbot", Oliva-Teles et al. (1999) observaram que a inclusão da proteína hidrolisada em substituição a uma determinada fração da farinha de peixe não melhorou os índices de desempenho dos peixes. Entretanto, o fato de já haver sido demonstrado que para o "turbot", os atrativos específicos são a inosina e inosina 5 monofosfato e não misturas de aminoácidos, explicou os resultados obtidos.

Cahu et al. (1999) avaliaram o uso de proteína hidrolisada de peixe - PHP (0, 19, 38 e 58\%) em substituição à farinha de peixe em rações para larvas de "sea bass". A incorporação de $19 \%$ de proteína hidrolisada aumentou significativamente a sobrevivência, comparado ao tratamento contendo somente farinha de peixe. Em adição, a incorporação deste ingrediente aumentou a qualidade das larvas, considerando o critério da formação do esqueleto. Algumas enzimas envolvidas na hidrólise da proteína e que atuam em diferentes fases da digestão, foram analisadas a fim de explicar os efeitos da proteína hidrolisada de peixe. O nível de secreção da tripsina foi maior para os tratamentos sem e com 19\% da PHP, do que para os tratamentos contendo 38 e $58 \%$ de PHP. O nível maior de PHP na dieta pode ter produzido uma explosão de nutrientes aminoácidos e peptídeos - no intestino, induzindo uma saturação nos mecanismos de absorção e transporte, o que explica, em parte, os efeitos negativos do alto nível de PHP. 
Xue \& Cui (2001) testaram o efeito de vários atrativos na dieta da "gibel carp" Carassius auratus gibelio, alimentados com ou sem substituição parcial de farinha de peixe por farinha de carne e ossos. Os atrativos utilizados foram betaína, glicina, lisina, metionina, fenilalanina e um extrato comercial de lula. A eficácia dos atrativos variou com a composição da dieta, ou seja, os peixes alimentados com dietas contendo farinha de peixe, não apresentaram diferença em relação àqueles que receberam os atrativos. Porém, quando parte da farinha de peixe foi substituída pela farinha de carne e ossos todos os atrativos promoveram aumento no consumo do alimento. Algumas substâncias presentes na farinha de peixe, provavelmente atuam como atrativos. Na dieta contendo farinha de carne e ossos, mesmo com reduzida quantidade de farinha de peixe, o efeito do atrativo foi menor, ou a farinha de carne e ossos acrescentou algum efeito deletério e, conseqüentemente, os peixes tornaram-se sensíveis àadição de atrativos.

\subsection{Exigências nutricionais}

Zeiton et al. (1976) mostraram que é economicamente desejável atingir o ponto ótimo de crescimento do animal utilizando os menores níveis protéicos na dieta. $\mathrm{O}$ uso de alimentos naturais na produção intensiva de peixes carnívoros invarialvelmente onera os custos de produção. O uso de dietas formuladas especificamente para cada espécie minimiza estes custos e permite a produção de peixes para o consumo e pesca esportiva.

A maioria dos peixes tem pouca habilidade em utilizar carboidratos como fonte de energia e deste modo, exige uma maior porcentagem de proteína dietética (Kikuchi, 1999; Lovell, 1989). Desta forma, em geral o conteúdo de proteína em rações comerciais para peixes é maior que em rações para animais domésticos, e pode variar de $30 \%$ até mais que $50 \%$ de proteína bruta.

As proteínas são os componentes orgânicos mais abundantes nos tecidos dos peixes, totalizando aproximadamente 65 a $75 \%$ do peso seco destes animais. Os peixes consomem proteína para obter os aminoácidos. No trato digestivo estas proteínas são hidrolizadas enzimaticamente, liberando aminoácidos livres que são distribuídos através da corrente sanguínea para os órgãos e tecidos, onde são utilizados continuamente no 
processo de síntese e degradação de proteínas durante o processo de crescimento ou reprodução, ou como fonte de energia (Millward, 1989). Se dietas com quantidade de proteína insuficiente ou composição em aminoácidos inadequada são fornecidas aos peixes, pode ocorrer redução no crescimento, diminuição da eficiência alimentar, imunodepressão e perda de peso em função da mobilização da proteína de alguns tecidos para manter as funções vitais. Por outro lado, se é fornecido aos peixes proteína em excesso, somente uma parte será usada para formação de tecido muscular e crescimento, e o restante será convertido em depósito de energia, em geral na forma de gordura (Millward, 1989; Wilson, 1989; Winfree \& Stickney, 1981).

As exigências em proteína de uma espécie e o teor de proteína de uma ração são influenciados por fatores como tamanho do peixe, função fisiológica, qualidade da proteína e fatores econômicos. Porém, não há evidência que a exigência em proteína, expressa em porcentagem da matéria seca, seja influenciada pela temperatura ambiente. Em geral, o ritmo de todas as funções fisiológicas ligadas à alimentação e ao crescimento aumenta conforme aumenta a temperatura. Entretanto, a taxa de crescimento pode aumentar mais rapidamente devido a uma melhora na conversão alimentar, associada a um aumento da quantidade de alimento ingerido por refeição (NRC, 1993). Page \& Andrews (1973), por exemplo, demonstraram que para o bagre do canal, 25\% de proteína na ração é adequado para peixes de 114 a 500 g, mas um teor de $35 \%$ de proteína induz crescimento mais rápido do que $25 \%$ de proteína para peixes de 14 a $100 \mathrm{~g}$.

Podoskina et al. (1997) não observaram variação na digestibilidade da proteína para trutas arco-íris alimentadas com dietas que continham $20 \%$ de amido de batata em diferentes formas: cru, hidrolisado com ácido, gelatinizado a $70^{\circ} \mathrm{C}$, a $100^{\circ} \mathrm{C}$, a $120^{\circ} \mathrm{C}$, ou a $134^{\circ} \mathrm{C}$ e dextrina. Podoskina et al. (1997) relatam ainda que a substituição do amido de batara cru por amido gelatinizado a $70^{\circ} \mathrm{C}$, não altera a relação hepatosomática (RHS). Peixes alimentados com amido hidrolizado com ácido, gelatinizado a $100^{\circ} \mathrm{C}$, a $120^{\circ} \mathrm{C}$ e a $134^{\circ} \mathrm{C}$ apresentaram RHS similares (1,28 a 1,34\%), significativamente maiores que os peixes alimentados com amido cru e gelatinizado a $70^{\circ} \mathrm{C}$. A RHS foi maior $(1,47 \%)$ para os peixes alimentados com dextrina. Bergot \& Breque (1983) também relatam que a 
digestibilidade da proteína para a truta arco-íris não é afetada pelas fontes de amido (cru ou cozido), comparadas em iguais níveis de alimentação.

Segundo Lovell (1989) as exigências em proteína do bagre do canal variam entre 25 a 35\% de PB dietética, em função de variações no tamanho, quantidade de alimento fornecida, quantidade de energia não protéica na dieta, qualidade da proteína, temperatura da água e quantidade de alimento natural disponível nos viveiros. Porém, Gatlin et al. (1986) observaram que em condições de laboratório a melhor taxa de crescimento para o bagre do canal era alcançada com $29 \%$ de PB, contrapondo resultados alcançados por Li \& Lovell (1992b) - 24\% de PB e 2,82 de taxa de eficiência protéica; Li \& Lovell (1992a) - 26\% de PB e 2,51 de taxa de eficiência protéica; e Robinson \& $\mathrm{Li}$ (1997), quando os peixes eram alimentados à vontade.

Se os organismos-alimento presentes em um sistema de produção contribuem para a quantidade de alimento ingerido diariamente, o nível de proteína na dieta pode ser menor. Outro meio de economizar a proteína é substituir parte deste nutriente por um componente rico em energia, como os lipídios. Entretanto, altos níveis de lipídio na dieta induzem altos níveis de deposição de lipídio na carcaça, podendo levar também, a uma redução no consumo de alimento e ingestão de proteína e outros nutrientes, causando queda na taxa de crescimento (Cho, 1990; Lovell, 1991). Os níveis de proteína bruta em dietas para salmonídeos, por exemplo, variam de 40 a 50\%. Entretanto, Cho (1990) recomenda que aminoácidos ou proteínas devam ser supridos em excesso em relação à energia digestível, ou seja, que a relação energia:proteína seja mantida entre 9 a $10 \mathrm{kcal}$ de energia metabolizável/g de proteína bruta.

As proteínas não são idênticas em seus valores nutricionais. $\mathrm{O}$ valor nutricional de uma fonte de proteína é função da sua digestibilidade e composição em aminoácidos. Existem alguns ingredientes protéicos que contêm altos níveis de proteína bruta, mas que contêm uma grande proporção de nitrogênio não-protéico. Neste caso, estes ingredientes não contribuem com aminoácidos suficientes para suprir as exigências nutricionais das espécies e simplesmente aumentam a produção de amônia e excreção de nitrogênio pelos peixes, com prejuízos à produtividade e à qualidade da água no sistema de produção (Cho, 1990). 
Alguns autores afirmam que $70 \%$ das calorias em rações de trutas são originárias da proteína. Quando lipídios ou carboidratos são adicionados como fonte de energia em dietas para a espécie, o conteúdo de proteína na dieta pode ser reduzido sem ocasionar redução no ganho de peso. Porém, a quantidade de proteína que pode ser substituída por carboidratos e lipídios é limitada, devido às características fisiológicas das trutas (Lee \& Putnam, 1973).

Os lipídios são compostos orgânicos insolúveis em água, mas solúveis em solventes orgânicos, que representam fontes concentradas de energia, vitaminas, pigmentos, e fatores de crescimento essenciais para os peixes. Peixes em ambientes naturais, não importando a temperatura da água ou sua salinidade, têm significativa quantidade de ácidos graxos poli-insaturados (20 ou mais carbonos) na carcaça, obtidos do alimento, principalmente algas (Sargent et al., 1989).

Murray et al. (1977) e Ufodike \& Matty (1983) sugerem que altos níveis de lipídios nos ingredientes podem reduzir a digestibilidade das proteínas para os peixes. Porém, a digestibilidade das gorduras não depende da quantidade fornecida, bem como não influencia a digestibilidade de outros nutrientes. Para Steffens (1989), a redução na digestibilidade da proteína em ingredientes com alto nível de lipídio pode estar relacionada àformação de peróxidos (complexos protéico-lipídicos oxidados).

A quantidade e o tipo de gordura dietética são particularmente importantes na composição corporal do pescado produzido em criação, bem como a quantidade de gordura na carcaça é primariamente determinada pelo nível de energia e pela relação energia:proteína da dieta. Desta maneira, o equilíbrio da relação energia:proteína e a manutenção de níveis adequados de lipídios em uma ração para peixes, são fatores determinantes do sucesso de uma criação.

Seenappa \& Devaraj (1995) avaliaram o efeito de diferentes níveis de proteína, gordura e carboidrato no crescimento, utilização de alimento e composição corporal de alevinos de Catla catla, e verificaram que alevinos da espécie apresentaram melhor desenvolvimento com dietas contendo 30 a 35\% de proteína quando os níveis de gordura e carboidrato foram 4 e 35\%, respectivamente. Somente a inclusão de carboidrato 
mostrou um efeito economizador de proteína: $20 \%$ de aumento de dextrina diminuiu $5 \%$ da proteína da dieta nas condições experimentais.

Talvez porque os peixes se desenvolveram em um ambiente onde carboidratos eram escassos, seus sistemas digestivo e metabólico parecem estar mais bem adaptados à utilização de proteínas e lipídios como fonte de energia (Wilson, 1994). Entretanto, alguns herbívoros e onívoros de águas quentes podem digerir e metabolizar os carboidratos relativamente bem. Para salmonídeos, por exemplo, proteínas e lipídios são os principais combustíveis, enquanto carboidratos, principalmente amido de plantas, são pouco utilizados como fonte de energia (Lovell, 1989; Wilson, 1989).

Segundo Deng et al. (2001), o esturjão branco apresenta intestino curto e a atividade da á-amilase nesta espécie é pequena, assim como em outras espécies de peixes carnívoros. O curto tempo de trânsito intestinal e limitada capacidade hidrolítica podem limitar a digestão e absorção e restringir a utilização de carboidratos complexos. Isto pode explicar porque uma alimentação contínua provou aumentar a utilização do amido pelo esturjão branco, quando comparado a uma única refeição.

Comparados aos lipídios, os carboidratos são relativamente baratos e fonte de energia prontamente disponível para muitas espécies de peixes. Qualquer imbalanço em relação às fontes de energia não protéicas e/ou aos níveis de inclusão podem afetar diretamente crescimento, conversão alimentar, retenção de nutrientes e composição corporal (Wilson, 1994). Jafri (1998) avaliou o efeito da relação carboidrato-lipídio para Clarias batrachus com base no ganho de peso, conversão alimentar, retenção de nutrientes e composição corporal, e observou que $27 \%$ de carboidrato e $8 \%$ de lipídio, correspondendo a uma relação CHO:L de 3,39 e 40\% de proteína bruta e 3,46 kcal/g de energia metabolizável, é ótimo para a espécie. Maiores níveis de carboidrato com baixos níveis de lipídio (43,00 CHO:L) ou baixo carboidrato com altos níveis de lipídio (0,02 CHO:L) podem resultar em crescimento reduzido e piora na conversão alimentar e também afetar a composição corporal. Estes resultados poderiam ser explicados pela redução no consumo de proteína e outros nutrientes causados pelos altos níveis de lipídio dietético, ou pela deficiência de ácidos graxos essenciais nas dietas contendo baixos teores de lipídio. 
Peragón et al. (1999) relatam que a digestibilidade dos carboidratos é melhor em peixes de água doce e quente do que em peixes marinhos de água fria. A relativa inabilidade de metabolizar carboidratos tem sido demonstrada para várias espécies de peixe e está relacionada à hiperglicemia, baixa atividade da hexoquinase do fígado, a falta da glucoquinase e ao baixo número de receptores da insulina. Em estudo com trutas arco-íris alimentadas com dietas contendo $23 \%$ de carboidratos ou sem carboidratos, os autores concluíram que os peixes que receberam a dieta livre de carboidrato mostraram uma significativa diminuição de crescimento, devido a um fenômeno de hipotrofia muscular e não devido a mudança no nível de hiperplasia muscular. Este comportamento é resultado de mudanças na relação proteína:DNA sem variação no conteúdo total de DNA. Em adição, a ausência de carboidrato aumentou a degradação da proteína e diminuiu a taxa de síntese de proteína no músculo branco da truta arco-íris. Em resumo, a ausência de carboidrato pode fazer com que uma importante fração dos aminoácidos seja liberada a partir da digestão da proteína muscular e da ração, para ser utilizado para gluconeogênese e não para síntese de proteína e crescimento.

Segundo Wilson (1994) é necessário fornecer uma quantidade apropriada de carboidratos (aproximadamente 20\%) para assegurar máxima utilização de outros nutrientes pelos peixes. Segundo Hutchins et al. (1998), o desempenho de juvenis de "sunshine bass" (híbrido de Morone chrysops x M. saxatilis) alimentados com dietas com $20 \%$ de carboidrato é melhor que dos peixes alimentados com dietas contendo $40 \%$ carboidratos. Peixes alimentados com glucose apresentaram baixos valores de eficiência alimentar e protéica, devido, possivelmente, à rápida absorção do monossacarídeo. Os valores de lipídio no músculo e gordura intraperitoneal foram maiores para os peixes alimentados com dietas contendo $11 \%$ de lipídio e $20 \%$ de carboidrato, do que para aqueles alimentados com dietas contendo $2 \%$ de lipídio e $40 \%$ de carboidrato ou sem carboidrato. Carboidratos dietéticos solúveis aumentaram a deposição de gordura na cavidade abdominal e no músculo, mas não no fígado. Os carboidratos absorvidos que não são utilizados como energia podem acumular no fígado como energia ou glicogênio após conversão. "Sunshine bass" alimentados com dietas contendo carboidratos apresentaram fígado maiores, com mais glicogênio e menos lipídio, matéria seca e 
proteína, quando comparados a peixes alimentados com dietas sem carboidrato. Segundo Wilson (1994), o tamanho do fígado e o conteúdo de glicogênio hepático tendem a aumentar com o aumento dos níveis de carboidrato dietético em muitas espécies de peixes.

O glicogênio é uma das muitas formas de armazenamento de energia consumida como alimento pelo peixe. É composto por 5.000 a 25.000 unidades de glicose e está presente no fígado em quantidades maiores do que no músculo. Para a truta arco-íris a quantidade de glicogênio do músculo chega a $6 \%$ da quantidade presente no fígado $(0,15 \%$ versus $2,5 \%$ do peso vivo). Entretanto, as quantidades totais de glicogênio presentes no fígado e músculo podem ser consideradas da mesma magnitude. Como conseqüência de uma intensa atividade física, as reservas de glicogênio no músculo podem diminuir em poucos minutos, sendo que o nível original não se restabelece em menos de 24 horas; durante esta fase de recuperação, o glicogênio do fígado diminui. No verão, carpas de 3 anos, bem alimentadas, apresentaram aproximadamente 320-550 mg de glicogênio no fígado (calculado sobre o peso úmido do fígado) por $100 \mathrm{~g}$ de peso vivo Durante um período sem alimentação, a quantidade de glicogênio do fígado diminuiu para $90-160 \mathrm{mg} / 100 \mathrm{~g}$ de carcaça, pois o glicogênio era utilizado para manutenção dos níveis de açúcar no sangue (Steffens, 1989).

Palmer \& Ryman (1972) introduziram uma solução de glicose no estômago de truta arco-íris e observaram uma severa hiperglicemia, associada a uma elevação na quantidade de glicogênio no fígado. Aparentemente, neste caso, os peixes apresentaram um estado de deficiência de insulina, o qual corresponde ao estado de diabetes em mamíferos. No caso da carpa, de acordo com estudos de Nagai e Ikeda (1971a, b), o carboidrato, como fonte de energia, não apresenta qualquer superioridade em relação à proteína ou lipídio. Em contraste aos mamíferos, sob condições de jejum, as reservas de gordura no fígado dos peixes são utilizadas de pronto, enquanto as reservas de glicogênio podem ser utilizadas posteriormente.

Nagai \& Ikeda (1971a, b) observaram ainda que durante os primeiros 20 dias sem alimentação, o nível de glicose no sangue aumenta (gluconeogênese), enquanto o nível de glicogênio no fígado permanece inalterado. Após 100 dias sem alimentação, as 
reservas de gordura se esgotam completamente, enquanto o fígado ainda contém 1,6\% de glicogênio (peso úmido). Durante esta fase, há uma diminuição de aproximadamente 50\% no nível de açúcar no sangue. Experimentos de alimentação com dietas contendo vários níveis de carboidratos revelaram que há um aumento no glicogênio do fígado e diminuição de açúcar no sangue em resposta a uma dieta contendo altos níveis de carboidratos e baixos níveis de proteína, e que os carboidratos não são particularmente efetivos como fonte de energia, mesmo para peixes onívoros, como as carpas.

Em resumo, o glicogênio hepático é considerado um estoque emergencial de energia, prontamente utilizável nos primeiros momentos de situações críticas de estresse (Christiansen \& Klungsoyr, 1987), mesmo porque os polissacarídeos são encontrados em todas as células dos animais e mais abundantemente no fígado, alcançando normalmente $7 \%$ do peso seco do tecido (Stryer, 1971). O ciclo do glicogênio hepático no catabolismo mostra que esta forma de reserva orgânica é muito mais importante como suprimento de intermediários metabólicos para processos biossintéticos, que como fonte de energia (Christiansen \& Klungsoyr, 1987). O glicogênio é um nutriente muito utilizado em adaptações bioquímicas em situação de estresse ambiental. Variações de $\mathrm{pH}$, dos níveis de oxigênio dissolvido na água, da salinidade, e períodos de grande esforço físico e mudanças de dietas podem resultar tanto em aumento como em diminuição do estoque de glicogênio tecidual (Moraes et al., 1996; Soengas et al., 1995).

Diversos estudos conduzidos com diferentes espécies de peixes nas mais diversas condições ambientais têm utilizado a avaliação da relação hepatosomática e do peso da gordura visceral como forma de quantificar o estoque energético em peixes (Bidinoto et al., 1997). Brown et al. (1992) estudaram efeitos de níveis de proteína dietética variando de 25 a 55\%, com incrementos de 5\%, na alimentação de juvenis do "sunshine bass" utilizando a RHS como uma medida relativa de estoque energético, e observaram que os valores da RHS encontrados eram inversamente proporcionais aos níveis de proteína, e diretamente proporcionais aos níveis de carboidratos digestíveis dietéticos, o que mostra que quanto menor o nível de proteína dietética, maior a utilização de carboidratos e a deposição de glicogênio no tecido hepático. Resultados semelhantes também foram relatados por Millikin (1982) para o "stripped bass". 
A relação entre a quantidade de gordura visceral e o peso do corpo também apresenta comportamento similar a RHS, ou seja, apresenta um declínio diretamente proporcional ao aumento da quantidade de proteína dietética (Brown et al., 1992). As reservas energéticas dos peixes são geralmente representadas por um acúmulo de gordura visceral. Tais reservas em peixes não sexualmente maduros podem acontecer como acúmulo de gordura muscular, e são necessárias para crescimento e como reserva energética para o período de falta de alimento ou anorexia de inverno (Wicker \& Johnson, 1987).

Para que os animais realizem todas suas reações bioquímicas, para a formação de novos tecidos, manutenção do balanço osmótico, movimentação das moléculas e muitas outras reações que necessitam de energia e que tornam a vida possível, bem como para realização de trabalho ou atividade muscular, é necessário que tenham um suprimento de energia constante. Esta energia pode vir da oxidação de componentes orgânicos após ingestão e absorção do alimento ingerido, ou das reservas corporais de proteínas, gorduras e glicogênio. Particularmente para os peixes, a quantidade de energia em uma dieta tem que estar ajustada à quantidade de proteína (Kaushik \& Médale, 1994; Smith, 1989).

Trabalhos desenvolvidos por Britz \& Hecht (1997), Catacutan \& Coloso (1995), Dias et al. (1998), El Sayed \& Teshima (1992), Garling \& Wilson (1976), Lee \& Putman (1973), Rojas \& Verdegem (1994), Samantaray \& Mohanty (1997) e Tibaldi et al. (1996), utilizando peixes carnívoros como material biológico, determinaram que a melhor relação energia:proteína para alimentação das espécies carnívoras está entre 7 e 9 kcal ED/g de proteína. Nesta mesma linha de pesquisa, estudos desenvolvidos por Sampaio et al. (2000), com juvenis de tucunaré, demonstraram que peixes com peso inicial de 10g, apresentaram um ganho de peso de $20 \mathrm{~g}$ em 60 dias com índices de conversão alimentar de 1,2:1, consumindo uma dieta seca contendo $41 \%$ de proteína bruta, $3.500 \mathrm{kcal} / \mathrm{kg}$ de ração e relação ED:PB de $8 \mathrm{kcal} / \mathrm{g}$ de proteína. Considerando que a exigência em proteína diminui com o aumento do tamanho do peixe, o autor concluiu peixes maiores podem consumir rações com 36 a 37\% de PB e 9 kcal/g de proteína, sem 
redução no ganho de peso e qualidade da carne do produto final, o que resulta em grande redução no preço das rações.

Trabalhando com juvenis de black bass com peso médio inicial de $14 \mathrm{~g}$, Portz et al. (2001) e Cyrino et al. (2000), demonstraram que a espécie apresenta exigências nutricionais mínimas de 43,59\% de PB e $3.871 \mathrm{kcal}$ de ED/kg de alimento e limites da relação ED:PB entre 7,78 e 8,83 kcal/g. Nestas condições, o black bass apresenta alto percentual de glicogênio hepático e aumento da RHS, mostrando uma alta capacidade de armazenamento da energia, tanto prontamente utilizável - glicogênio - como de reserva orgânica - lipídios. Apesar de ser um carnívoro por excelência, o black bass pode aproveitar bem rações contendo níveis de carboidratos entre 24-30\%. Para tanto, a quantidade de lipídios na dieta deve permanecer entre 10 e 12\%, a fim de que a relação energia:proteína não exceda um limite de $8,0 \mathrm{kcal}$ ED/g. Níveis superiores a estes induzem grandes acúmulos de gordura visceral e podem trazer problemas quanto a qualidade da carcaça.

A utilização de energia por peixes carnívoros tende a ser negativamente relacionada ao conteúdo de carboidrato e positivamente relacionada ao conteúdo de lipídios e proteína na dieta. Estima-se que dietas naturais para carnívoros contenham $50 \%$ de proteína e $50 \%$ de gordura em relação ao peso seco (Sullivan \& Reigh, 1995). O que parece ser uma alta exigência em proteína é realmente uma baixa exigência em energia e existem vários fatores que contribuem para esta alta eficiência energética (Lovell 1988; Smith, 1989). Segundo Lovell (1984a), a relação energia:proteína exigida pelos peixes é menor que aquela exigida por animais de sangue quente porque os peixes não têm que manter a temperatura corporal constante, dispendendo menos energia para a atividade muscular e para manter a posição na água do que os animais errestres, bem como gastam menos energia que os animais homeotérmicos para excretar os produtos nitrogenados. Isto possibilita aos peixes a utilização de proteína dietética como fonte de energia. Deste modo, rações balanceadas para peixes contêm de 30 a 35\% de proteína, ao passo que rações de frangos e suínos, por exemplo, contêm 18 a 23\%, ou 14 a 16\% de proteína, respectivamente (Lovell, 1984a; Lovell, 1988; Lovell, 1991). 
A proteína é responsável pela maior parte do custo de uma ração (Robinson \& Li, 1997). Se o teor de energia de uma dieta não for suficiente, ou se a proteína for de baixa qualidade, ela será deaminada no corpo para ser utilizada como fonte de energia para o metabolismo. Uma baixa relação energia:proteína pode reduzir a taxa de crescimento devido ao aumento da demanda metabólica para excreção de nitrogênio. Excesso de energia na ração pode causar deposição excessiva de gordura nos peixes, reduzir consumo de alimento - e, conseqüentemente, a ingestão de proteína total - e inibir a utilização de outros nutrientes (Cho, 1990).

Segundo Lovell (1984b) a quantidade ótima de energia metabolizável por grama de proteína em rações de peixes varia entre 6 e 8 kcal. Ainda segundo Lovell (1991), vários autores encontraram que a relação ótima de energia digestível:proteína (ED:PB) para bagre do canal em crescimento é 9,6 kcal/g, sendo que este valor aumenta com o tamanho do peixe. Uma dieta deficiente em energia em relação à proteína promoverá o uso da proteína como energia para manutenção e não para crescimento. Em contraste, uma dieta contendo excesso de energia pode reduzir consumo de alimento e deste modo, diminuir a ingestão de proteína e outros nutrientes essenciais necessários para máximo crescimento. Um excesso de energia dietética em relação a outros nutrientes pode levar a grandes acúmulos de gordura corporal, indesejáveis em peixes de mesa (Bromley, 1980; NRC, 1993; Winfree \& Stickney, 1981).

As necessidades em energia digestível para máximo ganho de peso foram determinadas para várias espécies, como por exemplo, para o bagre do canal $(600 \mathrm{~g}) \mathrm{em}$ 3.000; para o "red drum" (43g) em 3.200; para a tilápia do Nilo (50g) em 2.900; para carpa comum $(20 \mathrm{~g})$ em 2.900 e para truta arco-íris $(90 \mathrm{~g})$ em $3.600 \mathrm{kcal} / \mathrm{kg}$ (Daniels \& Robinson, 1986; Garling \& Wilson, 1976; Li \& Lovell, 1992 a,b; NRC, 1993). Segundo os autores, estas variações são ocasionadas pelos diferentes hábitos alimentares destes peixes.

Geralmente, peixes ficam mais gordurosos quando alimentados com dietas contendo altas relações ED:PB. Lovell (1986) avaliou o ganho de peso versus ganho de proteína de peixes que foram alimentados ad libitum com cinco níveis de energia digestível (ED): 2,2 a 4,6 kcal/g e duas porcentagens de proteína bruta (PB): 27 e 37\% 
por dez semanas. $\mathrm{O}$ autor verificou que o ganho de peso aumentou conforme aumentou ED na dieta em ambos os níveis de proteína. Entretanto, o ganho de proteína aumentou conforme aumentaram os níveis de ED somente no nível mais alto de proteína. Isto mostra que os peixes alimentados com baixa proteína na deta usam a energia adicional para acúmulo de gordura ao invés de ganho de proteína.

Lovell (1986) analisou ainda o efeito de dietas isocalóricas $(2,88 \mathrm{kcal}$ ED/g) e duas porcentagens de proteína ( 26 e 32\%) em bagre do canal, e mostrou que o ganho de peso foi quase o mesmo para os dois níveis de proteína. Entretanto os peixes alimentados com rações contendo $26 \%$ de PB, com maior relação de ED:PB (11,07), ganharam $24 \%$ mais gordura e apresentaram rendimento de carcaça 3,9\% menor.

Lee \& Putnam (1973) alimentaram trutas (4,76 g de peso médio) por 18 semanas com dietas purificadas, com relações energia:proteína variando de 6,17 a 13,7 $\mathrm{kcal} / \mathrm{g}$, e observaram que o consumo de alimento pela truta foi regulado pelo conteúdo de calorias na ração e que a utilização da proteína e taxa de retenção da proteína consumida aumentaram conforme aumentaram os níveis de amido, indicando que existe um efeito economizador da proteína pelo amido. Os peixes alimentados com dietas contendo baixa energia ganharam peso em taxas comparáveis àquelas de peixes que receberam dietas contendo alta energia, aumentando o consumo de alimento. A quantidade de gordura corporal aumentou com o aumento dos teores de gordura na dieta, enquanto uma relação inversa ocorreu em relação à proteína corporal. Os autores observaram ainda um aumento do volume do trato gastrointestinal dos peixes que receberam dietas com altos níveis de gordura em função da expansão dos cecos pilóricos e intestino, resultado de uma lenta passagem do alimento pelo trato gastrointestinal.

\subsection{Digestibilidade}

Os peixes utilizam em torno de $80 \%$ da matéria seca da ração. Para otimizar a formulação de rações, é necessário a determinação da digestibilidade dos ingredientes e nutrientes de uma dieta. $\mathrm{O}$ valor nutricional de um ingrediente está baseado não somente na composição química, mas também na quantidade de nutrientes ou energia que o peixe 
pode absorver ou utilizar. A disponibilidade dos nutrientes para os peixes deve ser definida principalmente em termos de digestibilidade. Esta descreve a fração de nutrientes dos ingredientes ingeridos que não são excretados nas fezes (NRC, 1993; Goddard \& McLean, 2001).

A estimativa de valores dos coeficientes de digestibilidade dos ingredientes de uma ração traz consequiências benéficas tanto econômicas (aproveitamento de nutrientes) como ecológicas (perdas de nitrogênio e fósforo para o ambiente). Além disso, a avaliação dos métodos de determinação dos coeficientes de digestibilidade é de fundamental importância, pois são eles que trarão a confiabilidade dos resultados.

Os métodos para determinar os coeficientes de digestibilidade podem ser classificados em diretos e indiretos. O método indireto envolve o uso de um marcador inerte, como o óxido de cromio $\left(\mathrm{Cr}_{2} \mathrm{O}_{3}\right)$, o qual é incluído na dieta em concentrações de 0,5 a $1,0 \%$. Considera-se que as quantidades do marcador no alimento e nas fezes permaneçam constantes durante o período experimental e que todo o marcador ingerido aparecerá nas fezes. Este método elimina a necessidade de coletar toda a excreta e permite que os peixes comam à vontade (NRC, 1993).

O método direto considera todo o alimento consumido e quantidade de fezes resultante, sendo que a medida do coeficiente é dada pela diferença da quantidade de nutrientes ingeridos e excretado pelas fezes (NRC, 1993). Independentemente do método de coleta utilizado, a coleta de fezes é a atividade que exige maior atenção e precisão em experimentos de digestibilidade. Trabalhando com truta arco-íris, Smith et al. (1980) mostraram que uma significativa quantidade de nitrogênio fecal pode ser lixiviado na água antes da coleta. Desta forma, os coeficientes de digestibilidade se tornam superestimados.

Marcadores utilizados em estudos de digestibilidade devem permitir incorporação à dieta de forma homogênea e serem analisados com segurança; ser indigerível e não afetar o metabolismo do animal; apresentar uma taxa de passagem através do intestino similar ao dos outros nutrientes; e ser higiênico e não causar danos ao ser humano e ao meio ambiente (Goddard \& McLean, 2001; Austreng et al., 2000). O uso do óxido de cromio como marcador inerte foi proposto em 1918 em estudos de 
digestiblidade em ruminantes e sua utilidade para estudos com peixes foi confirmado na década de 1960 e tem sido, desde então, o marcador mais utilizado em estudo de digestibilidade (Furukawa \& Tsukahara, 1966; Morales et al., 1999).

Entretanto, segundo Hanley (1987), o óxido de cromio pode se separar parcialmente da dieta durante a ingestão e passagem pelo trato gastrointestinal de tilápias. Em peixes, segundo Lied et al. (1982), o óxido de cromio não satisfaz os critérios para ser utilizado como marcador, porque nem sempre pode ser totalmente recuperado nas fezes e necessita ser incluído em altas concentrações $(0,5$ a 1,0\% da dieta) para conduzir a resultados homogêneos. Entretanto, altos níveis de óxido de cromio na dieta podem prejudicar a absorção e o metabolismo dos nutrientes em peixes.

De fato, trabalhando com híbridos de tilápia, Shiau \& Lin (1993) demostraram que a utilização de carboidratos pela espécie é afetada pela suplementação dietética com cromio, indicando que este elemento pode não ser totalmente inerte para os peixes. Em estudos com o "Arctic charr" Salvelinus alpinus, o uso de $1 \%$ de óxido de cromio na dieta reduziu a concentração de gordura nas fezes e alterou a flora bacteriana no intestino (Ringo, 1993). Recentes estudos com tilápia híbrida também indicam que o óxido de cromio (0,5 a 2,0\% da dieta) afeta a digestibilidade do carboidrato, crescimento e composição corporal dos peixes (Shiau \& Liang, 1995; Shiau \& Shy, 1998). Em contraste, Ng \& Wilson (1997), Fernandez et al. (1999) e Hillestad et al. (1999) não encontraram efeitos negativos do óxido de cromio nas estimativas de digestibilidade de macronutrientes em bagre do canal, "gilthead seabream" e salmão do Atlântico Salmo salar, respectivamente. Do mesmo modo, avaliando o efeito do uso de óxido de cromio como marcador em estudo de digestibilidade da proteína com Haliotis midae L., Shipton \& Britz (2001) sugerem que o óxido de cromio satisfaz as exigências necessárias, como descrito por Morales et al. (1999), para ser utilizado como marcador.

A aceitabilidade do alimento é influenciada pela cor e como o óxido de cromio torna o alimento verde, isto pode afetar o consumo. Segundo Austreng et al. (2000), os óxidos de ítrio, lantano e itérbio podem substituir o óxido de cromio em estudos de digestibilidade utilizando níveis de $100 \mathrm{mg} / \mathrm{kg}$ da dieta. 
Morales et al. (1999), avaliando a fibra bruta e ácidos insolúveis como marcadores, concluíram que os resultados mais consistentes encontrados quando comparados ao óxido de cromio, foram àqueles obtidos com o uso da fibra bruta como marcador. Quando o ácido insolúvel foi utilizado, houve uma tendência de superestimar os valores dos coeficientes de digestibilidade. As causas não estão bem elucidadas, mas segundo Morales et al. (1999), podem estar relacionadas à velocidade de passagem pelo trato gastrointestinal, pois uma significativa fração da cinza resistente à hidrólise pode ser absorvida pelo peixe, invalidando esta substância como marcador.

Goddard \& McLean (2001) citam que as vantagens do uso de ácidos insolúveis como marcadores em estudos de digestibilidade são o baixo custo, o fácil manejo, e a utilização de equipamentos laboratoriais básicos, que beneficiam os pesquisadores. Krogdahl (1989), classificou a fibra dietética em dois grupos: insolúveis em água, que compreendem a celulose, hemicelulose e a lignina e não são alterados pelo processo de digestão; e solúveis em água: que compreendem algumas hemiceluloses, pectinas, oligossacarídeos e podem ser alterados durante a passagem intestinal, mudando as características. Os farelos de soja e girassol, por exemplo, apresentam fibras solúveis, incluindo oligossacarídeos, que se alteradas pela digestão, podem contribuir para subestimar os coeficientes de digestibilidade. As proteínas presentes na maioria dos ingredientes são altamente digestíveis pelos peixes. Os coeficientes de digestibilidade de ingredientes protéicos variam entre 75 a $95 \%$ e normalmente os valores menores estão associados a concentrações maiores de carboidratos (Rychly \& Spannhof, 1979).

Durante o processamento da farinha de peixe, o superaquecimento pode diminuir consideravelmente o valor nutritivo. Da mesma forma, um aquecimento insuficiente do farelo de soja diminui a disponibilidade da proteína (NRC, 1993). Smith (1976) mostrou que o aumento da temperatura de processamento de $127^{\circ} \mathrm{C}$ para $204^{\circ} \mathrm{C}$, aumenta a digestibilidade da proteína do farelo de soja de 45 para $75 \%$.

Avaliando a digestibilidade de rações comerciais para salmões, Hillestad et al. (1999) relataram que os coeficientes de digestibilidade normalmente encontrados na Noruega têm sido 87, 90 e 65\% para proteína, gordura e carboidrato, respectivamente (Associação dos Produtores de Ração para Peixes da Noruega). Rações com 
aproximadamente mesma composição, podem apresentar até $10 \%$ de diferença na digestibilidade de energia, em função das diferentes fontes de energia, de proteína, ou de carboidratos utilizadas.

Os lipídios, quando administrados isoladamente ou contidos na dieta, apresentam digestibilidade de 85 a 95\%. Os valores de digestibilidade estimados para os lipídios, entretanto, variam freqüentemente quando as concentrações na dieta são baixas (NRC, 1993).

Watanabe \& Pongmaneerat (1993) concluíram que a adição do farelo de soja em rações extrusadas pode substituir até $90 \%$ da farinha de peixe em dietas para truta arco-íris, sem causar redução no crescimento ou taxa de eficiência protéica. Estes autores também notaram uma piora nos valores de conversão alimentar em dietas contendo altos níveis de farelo de soja, a qual eles atribuem à baixa digestibilidade do amido. Watanabe \& Pongmaneerat (1993) determinaram ainda a digestibilidade do amido no farelo de soja, de aproximadamente 54\%, independentemente do nível de inclusão na dieta. $\mathrm{O}$ amido não cozido apresenta somente $49 \%$ de digestibilidade para a truta arco-íris (NRC, 1993); entretanto, para o bagre do canal apresenta digestibilidade acima de $70 \%$ para a energia (Wilson \& Poe, 1985).

A atividade da amilase em truta arco-íris pode ser afetada pelo tipo e quantidade de carboidrato da dieta. Aksnes \& Opstvedt (1998), determinaram a energia digestível do farelo de soja para a truta arco-íris, como sendo menor que aquela determinada para a farinha de peixe, pois segundo os autores, o conteúdo de carboidrato no farelo de soja é maior e este nutriente apresenta baixa digestibilidade para salmonídeos. A incorporação de ingredientes de origem vegetal nas dietas pode afetar o tempo de passagem do alimento pelo trato gastrointestinal, como função da presença de fibras e açúcares (Storebakken et al., 1999).

Allan et al. (2000) avaliaram a digestibilidade de ingredientes alternativos à farinha de peixe em rações para a "silver perch" Bidyanus bidyanus. O coeficiente de digestibilidade encontrado foi de $99 \%$ para o trigo, com 12 a $15 \%$ de proteína e $80 \%$ de carboidrato, e a espécie foi considerada relativamente eficiente em digerir e utilizar carboidratos, o que pode explicar a ausência de relação entre o conteúdo de carboidrato e 
a digestibilidade do nitrogênio que, especialmente em ingredientes de origem animal que foram super-aquecidos, pode ser bastante diminuída em função da degradação da lisina e conseqüente diminuição da qualidade da proteína.

McGoogan \& Reigh (1996) relataram que a digestibilidade da proteína para o "red drum" foi maior para ingredientes com menos de $2 \%$ de fibra, mas acima deste nível, não existiu relação entre o conteúdo de fibra e digestibilidade da proteína. De fato, segundo Robinson et al. (1981), a fibra, composta basicamente de celulose, é praticamente indigerível para os peixes carnívoros e não tem qualquer valor na nutrição destas espécies, devendo ser restringida a menos que $7 \%$ da dieta.

A digestibilidade da proteína está negativamente relacionada com o conteúdo de carboidrato na dieta; altos níveis de carboidratos reduzem a atividade da enzima proteolítica e carboidratos não digestíveis passam rapidamente através do trato gastrintestinal, carreando algumas proteínas não digeridas e afetando, desta foram, a digestibilidade da proteína (Falge et al., 1978; Hepher, 1985). Entretanto, Storebakken et al. (1998) observaram que o aumento do conteúdo de carboidrato dietético (10-20\%) reduziu a digestibilidade da matéria seca, energia e gordura, mas pouco afetou a digestibilidade da proteína para truta arco-íris.

Quando comparados aos demais vertebrados na escala evolutiva, os peixes carnívoros possuem um sistema digestivo simples e pouco desenvolvido. Como conseqüência, têm pouca habilidade em utilizar carboidratos como fonte energética e exigem dietas com altos níveis de proteína, que garantem não só uma alta taxa de síntese de tecido muscular, como também o suprimento das necessidades energéticas (Millward, 1989). Em adição, as exigências nutricionais em aminoácidos dos peixes carnívoros, tanto quantitativos como qualitativas, condiciona o uso de ingredientes de origem animal na fabricação de rações para estas espécies, elevando o custo de produção.

Vários autores demonstraram que carboidratos e lipídios exercem um efeito economizador da proteína em peixes, sugerindo, por exemplo, a possibilidade de incluir 12 a $14 \%$ de extrato etéreo e 23,5 a 27,6\% de carboidrato em dietas extrusadas para o "sea bass" Dicentrarchus labrax (Jeong et al., 1991; Pérez et al. 1997; Pfeffer et al., 1991; 1995). Tal fato pode ser explicado pelo aumento na disponibilidade de alguns 
ingredientes pelo processo de extrusão (Akimoto et al., 1992; Takeuchi et al., 1990). Desta forma, as recomendações de Brecka et al. (1996) para que as rações comerciais sejam testadas e avaliadas em ensaios biológicos antes de serem disponibilizadas no mercado são muito pertinentes.

Segundo Gatlin (1999) a inclusão de carboidratos nas dietas representa uma importante fonte de energia. No entanto, a capacidade das espécies carnívoras hidrolisarem os carboidratos é limitada pela pouca atividade aminolítica no seu trato digestivo (Spannhof \& Plantikow, 1983). Bergot \& Breque (1983) mostraram que quanto maior a proporção de amido na dieta de salmonídeos, menor é a digestibilidade deste nutriente. Quando estes peixes são alimentados por um período muito longo com rações contendo altos níveis de carboidratos, observa-se uma diminuição no crescimento e acúmulo de glicogênio no tecido hepático, o que eventualmente causa mortalidade nos estoques mantidos em confinamento.

Embora proteínas e lipídios sejam as fontes de energia mais disponíveis para os peixes, a tilápia do Nilo e o bagre do canal, espécies onívoras de água quente, digerem cerca de $70 \%$ da energia bruta proveniente de amido não cozido. Por outro lado, a truta arco-íris, um carnívoro de água fria, digere menos que 50\%. O processamento de rações aumenta a digestibilidade do amido para os peixes. O milho extrusado possui $38 \%$ mais energia digestível para o bagre do canal que o milho peletizado e o amido gelatinizado possui 75\% mais energia digestível para truta arco-íris que o amido cru (NRC, 1993). Polissacarídeos e dissacarídeos digestíveis favorecem mais acentuadamente o crescimento que monossacarídeos, assim como o amido cozido ou gelatinizado possui maior digestibilidade e influencia mais positivamente o crescimento dos peixes que o amido cru (Robinson et al., 1981). 


\section{MATERIAL E MÉTODOS}

Os experimentos foram conduzidos no Laboratório de Nutrição de Peixes do Departamento de Zootecnia, Setor não Ruminantes da Escola Superior de Agricultura "Luiz de Queiroz", Campus "Luiz de Queiroz" da Universidade de São Paulo, em Piracicaba, SP. O laboratório possui um sistema fechado de recirculação de água com temperatura controlada por bomba de troca de calor $\left(27^{\circ} \mathrm{C} \pm 1,07^{\circ} \mathrm{C}\right)$, é iluminado por 8 lâmpadas de halogênio de $370 \mathrm{~W}$, controladas por temporizador, mantendo um fotoperíodo de 14L:10E. Os parâmetros de qualidade da água foram monitorados através de um medidor de oxigênio YSI-55; amônia e pH através do kit de análise de água modelo $\mathrm{HACH} / \mathrm{FF}-2$.

As análises químico-bromatológicas dos ingredientes, dietas, fezes e carcaça foram feitas em triplicatas com base na matéria seca. A proteína bruta foi analisada pelo método Kjeldahl (N x 6,25); o extrato etéreo após extração por éter de petróleo pelo método de Soxhlet e a fibra bruta pelo método de Weende. Cálcio foi determinado pelo método de oxidimetria, e fósforo, por colorimetria, após mineralização e digestão ácida. A energia foi estimada em uma bomba calorimétrica adiabática, utilizando ácido benzóico como padrão. Óxido de cromio foi analisado seguindo a metodologia de Furukawa \& Tsukahara (1966).

Os ingredientes utilizados na preparação das dietas foram moídos em peneira de $1,0 \mathrm{~mm}$, homogeneizados e misturados (misturador tipo "Y"), umedecidos com 50\% de água destilada e granulados $(2,0 \mathrm{~mm})$ em moinho de rosca sem-fim. Após secagem em estufa de ventilação forçada a $55^{\circ} \mathrm{C}$ por 24 horas, as rações permaneceram armazenadas em recipientes plásticos, herméticos, sob refrigeração $\left(4^{\circ} \mathrm{C}\right)$ durante todo o período 
experimental. Para montagem do experimento, os peixes foram submetidos a jejum por 24 horas, anestesiados em solução de benzocaína (100 mg/L), pesados em balança semianalítica $(0,001 \mathrm{~g})$ e distribuídos aleatoriamente nas parcelas.

\subsection{Experimento 1}

\section{Atrativos em dietas à base de proteína de origem vegetal para o black bass Micropterus salmoides}

Um mil cento e setenta juvenis de black bass $(24,48 \pm 1,19 \mathrm{~g})$ já condicionados a aceitar o alimento artificial seco para peixes carnívoros, foram distribuídos em aquários de polietileno com volume igual a 90 litros (15 peixes/aquário), em um delineamento experimental totalmente ao acaso, e alimentados durante 10 dias em duas refeições diárias $(07 \mathrm{~h} 00 \mathrm{~m}$ e $17 \mathrm{~h} 00 \mathrm{~m})$, com dietas isonitrogenadas (40\% proteína bruta) e isocalóricas (3.500 kcal de ED/kg) (Sampaio, 1998), suplementadas com seis níveis de quatro palatabilizantes (Tabela 1): silagem de peixe $(1,0,2,0,3,0,4,0,5,0$ e 6,0\%), Fisharon $^{\circledR}(0,02 ; 0,04 ; 0,06 ; 0,08 ; 0,10 ; 0,12 \%)$, proteína solúvel de peixe $(0,5 ; 1,0 ; 1,5$; $2,0 ; 2,5 ; 3,0 \%)$, e glicina $(0,5 ; 1,0 ; 1,5 ; 2,0 ; 2,5 ; 3,0 \%)$, um controle positivo (dieta contendo $10 \%$ de farinha de peixe) e um controle negativo (dieta basal sem palatabilizante), totalizando 78 parcelas $(n=3)$. Os teores de amido nas dietas foram fixados em 18\%. DL-metionina (98\%) e L-lisina (80\%) foram adicionadas automaticamente pela matriz do programa de formulação Brill Formulations no ajuste e balanceamento dos aminoácidos disponíveis (Tabelas 2 e 3). Os grânulos da ração eram administrados um a um até a saciedade. No final do experimento, os peixes foram anestesiados e foi obtido o peso final de cada parcela. Os parâmetros avaliados foram consumo de ração, ganho de peso e conversão alimentar.

Em função da alta variação dos resultados, repetiu-se o experimento. $\mathrm{O}$ atrativo glicina foi excluído por este não ter apresentado resultado esperado. No segundo ensaio, 900 juvenis de black bass $(26,54 \pm 1,53$ g) já condicionados a aceitar o alimento 
artificial seco para peixes carnívoros, foram distribuídos em aquários de polietileno com volume igual a 90 litros (15 peixes/aquário), em um delineamento experimental totalmente ao acaso, e alimentados por 13 dias, em duas refeições diárias (07h00m e 17h00m) com dietas contendo seis níveis de três palatabilizantes: silagem de peixe $(1,0$; $2,0 ; 3,0 ; 4,0 ; 5,0$ e $6,0 \%)$, Fisharon ${ }^{\circledR}(0,02 ; 0,04 ; 0,06 ; 0,08 ; 0,10 ; 0,12 \%)$ e proteína solúvel de peixe $(0,5 ; 1,0 ; 1,5 ; 2,0 ; 2,5 ; 3,0 \%)$, um controle positivo (dieta contendo $10 \%$ de farinha de peixe) e um controle negativo (dieta basal sem palatabilizante), num total de 60 parcelas $(n=3)$.

Também para este ensaio, DL-metionina (98\%) e L-lisina (80\%) foram adicionadas automaticamente pela matriz do programa de formulação Brill Formulations no ajuste e balanceamento dos aminoácidos disponíveis (Tabelas 2 e 3). Outra vez os grânulos da ração foram administrados um a um até a saciedade. Ao final do experimento os peixes foram anestesiados, foi obtido o peso final de cada parcela, e foam avaliados os parâmetros de consumo de ração, ganho de peso e conversão alimentar. Os resultados de desempenho dos peixes, correspondentes à média das três repetições das diferentes dietas experimentais foram submetidos à análise de variância (ANOVA) e ao teste de comparação de médias Tukey $(\mathrm{P}=0,05)$, pelo aplicativo estatístico SAS (1985).

Tabela 1. Composição nutricional dos atrativos utilizados nas dietas experimentais para juvenis de black bass

\begin{tabular}{lccc}
\hline & \multicolumn{3}{c}{ Atrativo } \\
\cline { 2 - 4 } Composição em nutrientes & *Fisharon ${ }^{\Theta}$ & Silagem de peixe & Proteína solúvel de peixe \\
\cline { 2 - 4 } Proteína, \% & 0,93 & 58,71 & 80,73 \\
Extrato etéreo, \% & 99,26 & 12,06 & 4,96 \\
Fibra bruta, \% & 0,09 & 0,28 \\
Matéria mineral, \% & 14,69 & 4,39 \\
Energia bruta, kcal/kg & $8.970,00$ & $4.587,00$ & $4.997,00$ \\
Cálcio, \% & 3,16 & 0,11 \\
Fósforo, \% & 2,29 & 0,36 \\
\hline * 12\% de óleo de fígado de bacalhau; 0,3\% de ácidos graxos; 0,4\% de óleo de "humo", 0,1\% de óleos essenciais naturais, \\
87\% de óleo de milho e 0,2\% de antioxidante (BHT).
\end{tabular}


Tabela 2. Formulação das dietas experimentais para juvenis de black bass

\begin{tabular}{|c|c|c|c|c|c|c|}
\hline \multirow[b]{2}{*}{ Ingrediente } & \multicolumn{6}{|c|}{ Dieta - Glicina } \\
\hline & G 0,5\% & G 1,0\% & G 1,5\% & G 2,0\% & G 2,5\% & G 3,0\% \\
\hline Milho & 8,52 & 8,39 & 10,26 & 12,95 & 15,64 & 18,32 \\
\hline Glúten de milho & 28,83 & 29,74 & 30,00 & 30,00 & 30,00 & 30,00 \\
\hline Farelo de trigo & 15,00 & 15,00 & 12,13 & 8,08 & 4,03 & 0,00 \\
\hline Óleo de soja & 5,94 & 5,94 & 5,96 & 5,99 & 6,01 & 6,04 \\
\hline Farelo de soja & 37,88 & 36,57 & 36,74 & 37,53 & 38,32 & 39,10 \\
\hline Fosfato bicálcico & 1,48 & 1,49 & 1,53 & 1,58 & 1,63 & 1,68 \\
\hline Glicina & 0,5 & 1,0 & 1,5 & 2,0 & 2,5 & 3,0 \\
\hline DL-Metionina (98\%) & 0,23 & 0,22 & 0,22 & 0,22 & 0,22 & 0,22 \\
\hline L-Lisina (80\%) & 0,81 & 0,85 & 0,86 & 0,85 & 0,84 & 0,84 \\
\hline \multirow[t]{2}{*}{ Mistural mineral e vitamínica } & 0,80 & 0,80 & 0,80 & 0,80 & 0,80 & 0,80 \\
\hline & \multicolumn{6}{|c|}{ Dieta - Proteína solúvel de peixe } \\
\hline Ingrediente & PSP 0,5\% & PSP 1,0\% & PSP $1,5 \%$ & PSP 2,0\% & PSP 2,5\% & PSP 3,0\% \\
\hline Milho & 8,80 & 8,94 & 9,08 & 9,22 & 9,36 & 9,50 \\
\hline Glúten de milho & 27,20 & 26,47 & 25,74 & 25,02 & 24,29 & 23,56 \\
\hline Farelo de trigo & 15,00 & 15,00 & 15,00 & 15,00 & 15,00 & 15,00 \\
\hline Óleo de soja & 5,92 & 5,91 & 5,90 & 5,88 & 5,87 & 5,86 \\
\hline Farelo de soja & 39,32 & 39,44 & 39,57 & 39,69 & 39,81 & 39,94 \\
\hline Fosfato bicálcico & 1,48 & 1,48 & 1,48 & 1,49 & 1,49 & 1,50 \\
\hline PSP & 0,5 & 1,0 & 1,5 & 2,0 & 2,5 & 3,0 \\
\hline DL-Metionina (98\%) & 0,23 & 0,23 & 0,23 & 0,23 & 0,23 & 0,23 \\
\hline L-Lisina (80\%) & 0,75 & 0,72 & 0,70 & 0,67 & 0,64 & 0,62 \\
\hline \multirow[t]{2}{*}{ Mistural mineral e vitamínica } & 0,80 & 0,80 & 0,80 & 0,80 & 0,80 & 0,80 \\
\hline & \multicolumn{6}{|c|}{ Dieta-Fisharon $^{(2)}$} \\
\hline Ingrediente & FA 0,02\% & FA 0,04\% & FA $0,06 \%$ & FA $0,08 \%$ & FA $0,10 \%$ & FA $0,12 \%$ \\
\hline Milho & 8,66 & 8,66 & 8,66 & 8,66 & 8,66 & 8,66 \\
\hline Glúten de milho & 27,93 & 27,93 & 27,93 & 27,93 & 27,93 & 27,92 \\
\hline Farelo de trigo & 15,00 & 15,00 & 15,00 & 15,00 & 15,00 & 15,00 \\
\hline Óleo de soja & 5,92 & 5,90 & 5,88 & 5,86 & 5,83 & 5,81 \\
\hline Farelo de soja & 39,20 & 39,20 & 39,20 & 39,20 & 39,20 & 39,20 \\
\hline Fosfato bicálcico & 1,47 & 1,47 & 1,47 & 1,47 & 1,47 & 1,47 \\
\hline Fisharon $^{\circledR}$ & 0,02 & 0,04 & 0,06 & 0,08 & 0,10 & 0,12 \\
\hline DL-Metionina (98\%) & 0,23 & 0,23 & 0,23 & 0,23 & 0,23 & 0,23 \\
\hline L-Lisina (80\%) & 0,78 & 0,78 & 0,78 & 0,78 & 0,78 & 0,78 \\
\hline Mistural mineral e vitamínica & 0,80 & 0,80 & 0,80 & 0,80 & 0,80 & 0,80 \\
\hline
\end{tabular}


Tabela 2. Formulação das dietas experimentais para juvenis de black bass

\begin{tabular}{|c|c|c|c|c|c|c|}
\hline \multirow[b]{2}{*}{ Ingrediente } & \multicolumn{6}{|c|}{ Dieta - Silagem de peixe } \\
\hline & SP $1,0 \%$ & SP $2,0 \%$ & SP $3,0 \%$ & SP $4,0 \%$ & SP $5,0 \%$ & SP $6,0 \%$ \\
\hline Milho & 8,44 & 8,46 & 8,47 & 8,48 & 8,49 & 8,50 \\
\hline Glúten de milho & 29,59 & 29,73 & 29,88 & 30,02 & 30,17 & 30,33 \\
\hline Farelo de trigo & 15,00 & 15,00 & 15,00 & 15,00 & 15,00 & 15,00 \\
\hline Óleo de soja & 5,85 & 5,75 & 5,66 & 5,57 & 5,47 & 5,37 \\
\hline Farelo de soja & 35,87 & 34,75 & 33,63 & 32,51 & 31,39 & 30,27 \\
\hline Fosfato bicálcico & 2,34 & 2,35 & 2,37 & 2,38 & 2,39 & 2,40 \\
\hline Silagem de peixe & 1,0 & 2,0 & 3,0 & 4,0 & 5,0 & 6,0 \\
\hline DL-Metionina (98\%) & 0,23 & 0,23 & 0,24 & 0,24 & 0,25 & 0,25 \\
\hline L-Lisina (80\%) & 0,88 & 0,92 & 0,96 & 1,00 & 1,04 & 1,08 \\
\hline \multirow[t]{2}{*}{ Mistural mineral e vitamínica } & 0,80 & 0,80 & 0,80 & 0,80 & 0,80 & 0,80 \\
\hline & \multicolumn{4}{|c|}{ Dieta controle } & & \\
\hline Ingrediente & \multicolumn{2}{|c|}{ T25-Controle positivo } & \multicolumn{2}{|c|}{ T-26-Controle negativo } & & \\
\hline Milho & \multicolumn{2}{|c|}{10,64} & \multicolumn{2}{|c|}{8,66} & & \\
\hline Glúten de milho & \multicolumn{2}{|c|}{18,05} & \multicolumn{2}{|c|}{27,93} & & \\
\hline Farelo de trigo & \multicolumn{2}{|c|}{15,00} & \multicolumn{2}{|c|}{15,00} & & \\
\hline Óleo desoja & \multicolumn{2}{|c|}{4,90} & \multicolumn{2}{|c|}{5,94} & & \\
\hline Farelo de soja & \multicolumn{2}{|c|}{39,07} & \multicolumn{2}{|c|}{39,19} & & \\
\hline Farinha de peixe & \multicolumn{2}{|c|}{10,00} & \multicolumn{2}{|c|}{0,00} & & \\
\hline Fosfato bicálcico & \multicolumn{2}{|c|}{1,11} & \multicolumn{2}{|c|}{1,47} & & \\
\hline DL-Metionina (98\%) & \multicolumn{2}{|c|}{0,19} & \multicolumn{2}{|c|}{0,23} & & \\
\hline L-Lisina (80\%) & \multicolumn{2}{|c|}{0,24} & \multicolumn{2}{|c|}{0,78} & & \\
\hline Mistural mineral e vitamínica & \multicolumn{2}{|c|}{0,80} & \multicolumn{2}{|c|}{0,80} & & \\
\hline
\end{tabular}

${ }^{\mathrm{a}}$ Composição dos ingredientes (g/100g MS):

- milho: proteína bruta 10,4; extrato etéreo, 4,21

- farinha de peixe importada: proteína bruta, 71,52; extrato etéreo, 13,22; índice de acidez, 5,53;

- farelo de soja: proteína bruta, 51,40; extrato etéreo, 6,71, urease:0,03, solubilidade:80,93

- glúten de milho: proteína bruta, 71,24; extrato etéreo, 3,60

- farelo de trigo: proteína bruta, 17,12.

b Suplementação/kg de ração: vitamina A 8.000 UI; vitamina D 4.000 UI; vitamina E 160 UI; vitamina K 4 $\mathrm{mg}$; vitamina C $320 \mathrm{mg}$; tiamina $10 \mathrm{mg}$; riboflavina $20 \mathrm{mg}$; piridoxina $15 \mathrm{mg}$; vitamina $\mathrm{B}_{12} 30 \mathrm{mcg}$; ácido pantotênico $40 \mathrm{mg}$; niacina $40 \mathrm{mg}$; ácido fólico $2 \mathrm{mg}$; biotina $900 \mathrm{mcg}$; colina $1.000 \mathrm{mg}$; Mn 30 mg; Zn 160 mg; Fe 110 mg; Cu 16 mg; I 0,6 mg; Se 0,6 mg. 
Tabela 3. Composição nutricional das dietas experimentais para juvenis de black bass

\begin{tabular}{lcccccccccc}
\hline & \multicolumn{10}{c}{ Dieta } \\
\cline { 2 - 10 } Nutrientes & PSP 0,5\% & PSP 1,0\% & PSP 1,5\% & PSP 2,0\% & PSP 2,5\% & PSP 3,0\% & FA 0,02\% & FA 0,04\% & FA 0,06\% & FA 0,08\% \\
\hline Proteína, \% & 39,54 & 37,68 & 39,53 & 39,68 & 38,50 & 39,75 & 38,17 & 39,20 & 39,15 & 36,71 \\
Extrato etéreo, \% & 8,51 & 9,69 & 9,92 & 10,26 & 10,43 & 9,63 & 10,39 & 10,36 & 10,05 & 9,99 \\
Matéria mineral, \% & 5,52 & 5,44 & 5,52 & 5,54 & 5,39 & 5,38 & 5,52 & 5,52 & 5,37 & 5,51 \\
Fibra bruta, \% & 4,54 & 5,16 & 4,02 & 4,64 & 3,74 & 3,80 & 4,49 & 4,64 & 4,66 & 4,75 \\
Energia bruta, kcal/kg & $4.740,0$ & $4.584,0$ & $4.704,0$ & $4.765,0$ & $4.812,0$ & $4.943,0$ & $4.827,0$ & $4.474,0$ & $4.754,0$ & $4.775,0$ \\
\hline Nutrientes & FA 0,10\% & FA 0,12\% & SP 1,0\% & SP 2,0\% & SP 3,0\% & SP 4,0\% & SP 5,0\% & SP 6,0\% & CP 10\%FP CN 100\%PV \\
\hline Proteína, \% & 37,29 & 39,29 & 37,75 & 40,39 & 40,55 & 40,23 & 38,39 & 40,07 & 40,68 & 39,33 \\
Extrato etéreo, \% & 9,93 & 9,76 & 10,20 & 9,25 & 10,39 & 10,01 & 9,79 & 10,15 & 9,76 & 9,61 \\
Matéria mineral, \% & 5,35 & 5,51 & 6,05 & 6,39 & 5,99 & 6,24 & 6,38 & 5,49 & 6,41 & 5,40 \\
Fibra bruta, \% & 4,44 & 4,36 & 4,59 & 4,38 & 4,53 & 4,46 & 4,21 & 4,05 & 4,59 & 3,98 \\
Energia bruta, kcal/kg & $4.778,0$ & $4.722,0$ & $4.917,0$ & $4.732,0$ & $4.946,0$ & $4.781,0$ & $4.813,0$ & $4.824,0$ & $4.654,0$ & $4.915,0$ \\
\hline
\end{tabular}




\subsection{Experimento 2}

\section{Substituição de fontes protéicas de origem animal por fontes protéicas de origem vegetal em dietas para o black bass Micropterus salmoides}

Quinhentos e sessenta juvenis de black bass $(3,06 \pm 0,20 \mathrm{~g})$ já condicionados a aceitar o alimento artificial seco para peixes carnívoros, foram distribuídos em gaiolas de volume igual a $60 \mathrm{~L}$ (20 peixes/gaiola), confeccionadas em tela de policroleto de vinila atóxico com abertura de malha de $5 \mathrm{~mm}$, alojadas em tanques de polipropileno de 1.000 L. Um lote de 20 peixes foi sacrificado por superdosagem em benzocaína, triturado, congelado de imediato por imersão em nitrogênio líquido e armazenado em super congelador, para determinação da composição corporal inicial (matéria seca) (Tabela 4).

Os peixes foram alimentados em duas refeições diárias $(07 \mathrm{~h} 00 \mathrm{~m}$ e $17 \mathrm{~h} 00 \mathrm{~m})$ por 43 dias com sete dietas isonitrogenadas (40\% proteína bruta) e isocalóricas (3.500 kcal de $\mathrm{ED} / \mathrm{kg}$ ) (Sampaio, 1998) ( $\mathrm{n}=4$ ), formuladas utilizando a matriz de formulação do programa Brill Formulations. Os ingredientes protéicos de origem animal foram incluídos em proporções que variaram de 0 a $60 \%$, definindo os seguintes tratamentos: 100PV:0PA (proteína vegetal: proteína animal); 100PV+atrativo $\left(0,02 \%\right.$ Fisharon $\left.^{\circledR}\right)$; 80PV:20PA; 60PV:40PA; 40PV:60PA; ração controle; 50PV:50PA (sem farinha de peixe). Os valores de farinha de peixe e farinha de penas foram fixados em $7 \%$ de inclusão enquanto a farinha de vísceras e a farinha de carne foram limitadas em 15\%. Os teores de amido das dietas foram fixados em 18\%. DL-metionina (98\%) e L-lisina (80\%) foram adicionadas automaticamente pela matriz do programa de formulação Brill Formulations no ajuste e balanceamento dos aminoácidos disponíveis (Tabela 5).

Os grânulos da ração foram administrados um a um até a saciedade. Houve apenas uma casualidade no tratamento 100PV:0PA. No final do experimento, os peixes foram anestesiados e foi obtido o peso final de cada parcela. Os peixes foram abatidos e uma amostra de cinco peixes de cada parcela foi coletada e armazenada $\left(4^{\circ} \mathrm{C}\right)$ para posterior análise de composição corporal (matéria seca). Os quinze peixes restantes 
foram utilizados para registro do peso vivo e do fígado, e consequente cálculo da relação hepatosomática. Os fígados e uma amostra do tecido muscular foram imediatamente congelados e mantidos em nitrogênio líquido para posterior análise de glicogênio.

Foram avaliados os seguintes parâmetros de desempenho: ganho de peso - GP = peso final - peso inicial $(\mathrm{g})$; consumo de ração $-\mathrm{CR}=$ alimento consumido no período (g); conversão alimentar $-\mathrm{CA}=$ alimento ingerido $\div$ ganho de peso (g:g); taxa de eficiência protéica - TEP $=$ ganho de peso $(\mathrm{g}) \div$ proteína consumida $(\mathrm{g})$ x $100(\%)$; retenção protéica $-\mathrm{RP}=$ [peso corporal final $\mathrm{x}$ proteína corporal final - peso corporal inicial x proteína corporal inicial] $\div$ total de proteína ingerida x $100(\%)$; retenção enegética $-\mathrm{RE}=$ [peso corporal final $\mathrm{x}$ energia corporal final - peso corporal inicial $\mathrm{x}$ energia corporal inicial $\div \div$ total de energia ingerida $\mathrm{x} 100$; e relação hepatosomática RHS $=$ (peso do fígado $\div$ peso corporal) $\mathrm{x} 100$. Os resultados foram submetidos à análise de variância (ANOVA) e ao teste de comparação de médias Tukey $(\mathrm{P}<0,05)$, pelo aplicativo estatístico SAS (1985).

Tabela 4. Composição corporal dos juvenis de black bass no ínicio do experimento (matéria seca)

\begin{tabular}{lcc}
\hline & Composição corporal & Composição do fígado \\
\hline Umidade, \% & 77,08 & 70,65 \\
Proteína, \% & 60,09 & 0,827 \\
Extrato etéreo, \% & 17,42 & \\
Fibra bruta, \% & 0,10 & \\
Matéria mineral, \% & 12,80 & 3,74 \\
Cálcio, \% & 4,39 & \\
Fósforo, \% & 2,73 & \\
E.B., kcal/kg & $5.432,00$ & \\
\hline
\end{tabular}


Tabela 5. Ingredientes e níveis nutricionais analisados nas dietas experimentais (matéria seca)

\begin{tabular}{|c|c|c|c|c|c|c|c|}
\hline \multirow[b]{2}{*}{ Ingrediente $^{\mathrm{a}}$} & \multicolumn{7}{|c|}{ Dieta } \\
\hline & 100PV:OPA & $100 P V+A$ & 80PV:20PA & 60PV:40PA & 40PV:60PA & Controle & 50PV:50PA \\
\hline Milho & 8,66 & 8,66 & 11,30 & 21,62 & 15,02 & 0,00 & 13,67 \\
\hline Glúten de milho & 27,93 & 27,93 & 17,14 & 2,80 & 1,67 & 2,53 & 8,00 \\
\hline Sorgo & 0,00 & 0,00 & 0,00 & 0,00 & 0,00 & 18,97 & 0,00 \\
\hline Farelo de trigo & 15,00 & 15,00 & 15,00 & 4,22 & 15,00 & 9,50 & 15,00 \\
\hline Óleo de soja & 5,94 & 5,92 & 4,55 & 3,85 & 1,31 & 4,15 & 1,97 \\
\hline Óleo de peixe & 0,00 & 0,00 & 0,00 & 0,00 & 0,00 & 2,08 & 0,00 \\
\hline Farelo de soja & 39,19 & 39,19 & 37,68 & 42,41 & 23,81 & 34,97 & 24,67 \\
\hline Farinha de carne & 0,00 & 0,00 & 0,00 & 0,00 & 14,88 & 0,00 & 15,00 \\
\hline Farinha de vísceras & 0,00 & 0,00 & 5,49 & 11,96 & 15,00 & 15,00 & 15,00 \\
\hline Farinha de penas & 0,00 & 0,00 & 0,00 & 5,00 & 5,00 & 7,00 & 5,00 \\
\hline Farinha de peixe & 0,00 & 0,00 & 7,00 & 7,00 & 7,00 & 5,00 & 0,00 \\
\hline Fisharon $^{\circledR}$ & 0,00 & 0,02 & 0,00 & 0,00 & 0,00 & 0,00 & 0,00 \\
\hline Fosfato bicálcico & 1,47 & 1,47 & 0,52 & 0,00 & 0,00 & 0,00 & 0,00 \\
\hline DL-Metionina (98\%) & 0,23 & 0,23 & 0,22 & 0,34 & 0,37 & 0,00 & 0,40 \\
\hline L-Lisina $(80 \%)$ & 0,78 & 0,78 & 0,30 & 0,00 & 0,14 & 0,00 & 0,49 \\
\hline Minerais e vitaminas ${ }^{b}$ & 0,80 & 0,80 & 0,80 & 0,80 & 0,80 & 0,80 & 0,80 \\
\hline Preços/kg & 0,983 & 0,995 & 0,973 & 0,883 & 0,791 & 0,762 & 0,750 \\
\hline \multicolumn{8}{|c|}{ Composição em nutrientes } \\
\hline Proteína, \% & 41,91 & 42,52 & 41,66 & 41,35 & 40,85 & 39,88 & 40,35 \\
\hline Extrato etéreo, \% & 9,67 & 9,40 & 9,73 & 8,94 & 8,59 & 12,18 & 8,77 \\
\hline Fibra bruta, \% & 3,72 & 3,93 & 4,08 & 3,64 & 3,77 & 4,41 & 3,84 \\
\hline Matéria mineral, \% & 5,40 & 5,45 & 6,20 & 6,69 & 13,67 & 6,40 & 13,33 \\
\hline E.B., $\mathrm{kcal} / \mathrm{kg}$ & $4.811,00$ & $4.818,00$ & $4.847,00$ & $4.614,00$ & $4.461,00$ & $4.791,00$ & $4.051,00$ \\
\hline
\end{tabular}

${ }^{\mathrm{a}}$ Composição dos ingredientes (g/100g MS):

- milho: proteína bruta 10,4; extrato etéreo, 4,21

- farinha de peixe importada: proteína bruta, 71,52; ext rato etéreo, 13,22; índice de acidez, 5,53;

- farelo de soja: proteína bruta, 51,40; extrato etéreo, 6,71, uréase:0,03, solubilidade:80,93

- glúten de milho: proteína bruta, 71,24; extrato etéreo, 3,60

- farelo de trigo: proteína bruta, 17,12.

- sorgo: proteína b ruta, 9,47; extrato etéreo, 2,65;

- farinha de peixe importada: proteína bruta, 71,52; extrato etéreo, 13,22; índice de acidez, 5,53;

- farinha de carne: proteína bruta, 41,19; extrato etéreo, 16,01; índice de acidez, 0,69;

- farinha de vísceras: proteína bruta, 61,79; extrato etéreo, 10,32; índice de acidez, 3,35;

- farinha de penas: proteína bruta, 80,28; extrato etéreo, 7,44; índice de acidez, 1,76.

b Suplementação/kg de ração: vitamina A 8.000 UI; vitamina D 4.000 UI; vitamina E 160 UI; vitamina K 4 $\mathrm{mg}$; vitami na C $320 \mathrm{mg}$; tiamina $10 \mathrm{mg}$; riboflavina $20 \mathrm{mg}$; piridoxina $15 \mathrm{mg}$; vitamina $\mathrm{B}_{12} 30 \mathrm{mcg}$; ácido pantotênico $40 \mathrm{mg}$; niacina $40 \mathrm{mg}$; ácido fólico $2 \mathrm{mg}$; biotina $900 \mathrm{mcg}$; colina $1.000 \mathrm{mg}$; Mn $30 \mathrm{mg}$; Zn 160 mg; Fe 110 mg; Cu 16 mg; I 0,6 mg; Se 0,6 mg. 


\subsection{Experimento 3}

\section{Digestibilidade de dietas à base de fontes protéicas de origem animal ou vegetal para o black bass Micropterus salmoides}

Foram formuladas sete dietas isonitrogenadas (40\% proteína bruta) e isocalóricas (3.500 kcal de ED/kg) (Sampaio, 1998), adicionadas do marcador inerte óxido de cromio $\left(\mathrm{Cr}_{2} \mathrm{O}_{3}\right)$ na concentração de $0,50 \%$ da dieta, utilizando a matriz de formulação do programa Brill Formulations. Os ingredientes protéicos de origem animal foram incluídos em proporções que variaram de 0 a $60 \%$, definindo os seguintes tratamentos: 100PV:0PA (proteína vegetal: proteína animal); 100PV+atrativo (0,02\% Fisharon $^{\circledR}$ ); 80PV:20PA; 60PV:40PA; 40PV:60PA; ração controle; 50PV:50PA (sem farinha de peixe). Os valores de farinha de peixe e farinha de penas foram fixados em $7 \%$ de inclusão enquanto a farinha de vísceras e a farinha de carne foram limitadas em $15 \%$. Os teores de amido foram fixados em 18\%. DL-metionina (98\%) e L-lisina (80\%) foram adicionadas automaticamente pelo programa de formulação no ajuste e balanceamento dos aminoácidos disponíveis (Tabela 6).

Cada ração era administrada a 280 juvenis de black bass $(27,0 \mathrm{~g})$ condicionados a aceitar alimento inerte e distribuídos em 4 gaiolas plásticas $(80 \mathrm{~L})$, rígidas, de fundo vazado, mantidas em tanques de polipropileno (1.000 L). Os peixes foram alimentados ad libitum em três refeições diárias $(7 \mathrm{~h} 00 \mathrm{~m}, 12 \mathrm{~h} 00 \mathrm{~m}$ e $17 \mathrm{~h} 00 \mathrm{~m})$ com as rações experimentais, durante 30 dias. Terminada a última refeição, os peixes eram anestesiados (benzocaína $100 \mathrm{mg} / \mathrm{L}$ ) e as gaiolas transferidas para aquários de fibra de vidro, de formato cilíndrico-cônico, com capacidade para 200 L, equipados com aerador, troca parcial de água e recipiente coletor de fezes refrigerado, onde permaneciam por um período de 10 horas. As fezes foram coletadas por sedimentação em recipiente refrigerado, centrifugadas $\left(4^{\circ} \mathrm{C}\right)$ por 15 minutos e armazenadas em supercongelador. As amostras foram submetidas à análise bromatológica e à determinação do $\mathrm{Cr}_{2} \mathrm{O}_{3}$ seguindo metodologia de Furukawa \& Tsukahara (1966). 
Tabela 6. Ingredientes e níveis nutricionais analisados nas dietas experimentais (matéria seca)

\begin{tabular}{|c|c|c|c|c|c|c|c|}
\hline \multirow[b]{2}{*}{ Ingrediente $^{a}$} & \multicolumn{7}{|c|}{ Dieta } \\
\hline & 100PV:OPA & $100 P V+A$ & 80PV:20PA & 60PV:40PA & 40PV:60PA & Controle & 50PV:50PA \\
\hline Milho & 8,68 & 8,68 & 11,16 & 24,11 & 14,89 & 0,00 & 13,55 \\
\hline Glúten de milho & 29,82 & 29,82 & 17,99 & 2,95 & 2,51 & 2,53 & 8,83 \\
\hline Sorgo & 0,00 & 0,00 & 0,00 & 0,00 & 0,00 & 18,47 & 0,00 \\
\hline Farelo de trigo & 15,00 & 15,00 & 15,00 & 0,57 & 15,00 & 9,50 & 15,00 \\
\hline Óleo de soja & 5,69 & 5,67 & 4,55 & 3,87 & 1,31 & 4,15 & 1,96 \\
\hline Óleo de peixe & 0,00 & 0,00 & 0,00 & 0,00 & 0,00 & 2,08 & 0,00 \\
\hline Farelo de soja & 36,94 & 36,94 & 36,43 & 42,90 & 22,58 & 34,97 & 23,44 \\
\hline Farinha de carne & 0,00 & 0,00 & 0,00 & 0,00 & 14,88 & 0,00 & 15,00 \\
\hline Farinha de vísceras & 0,00 & 0,00 & 5,49 & 11,96 & 15,00 & 15,00 & 15,00 \\
\hline Farinha de penas & 0,00 & 0,00 & 0,00 & 5,00 & 5,00 & 7,00 & 5,00 \\
\hline Farinha de peixe & 0,00 & 0,00 & 7,00 & 7,00 & 7,00 & 5,00 & 0,00 \\
\hline Fisharon $^{\circledR}$ & 0,00 & 0,02 & 0,00 & 0,00 & 0,00 & 0,00 & 0,00 \\
\hline Fosfato bicálcico & 1,49 & 1,49 & 0,53 & 0,00 & 0,00 & 0,00 & 0,00 \\
\hline DL-Metionina(98\%) & 0,22 & 0,22 & 0,22 & 0,34 & 0,36 & 0,00 & 0,40 \\
\hline L-Lisina $(80 \%)$ & 0,86 & 0,86 & 0,34 & 0,00 & 0,17 & 0,00 & 0,52 \\
\hline Óxido de cromio & 0,50 & 0,50 & 0,50 & 0,50 & 0,50 & 0,50 & 0,50 \\
\hline Minerais e vitaminas ${ }^{b}$ & 0,80 & 0,80 & 0,80 & 0,80 & 0,80 & 0,80 & 0,80 \\
\hline \multicolumn{8}{|c|}{ Composição em nutrientes } \\
\hline Proteína, \% & 43,27 & 44,44 & 42,97 & 43,24 & 41,44 & 41,06 & 42,09 \\
\hline Extrato etéreo, \% & 7,81 & 7,96 & 8,41 & 8,48 & 6,98 & 10,71 & 7,05 \\
\hline Fibra bruta, \% & 2,19 & 2,58 & 2,03 & 2,51 & 2,34 & 2,26 & 1,98 \\
\hline Cálcio, \% & 0,86 & 0,93 & 1,14 & 3,96 & 4,16 & 1,35 & 3,70 \\
\hline Fósforo, \% & 0,83 & 1,06 & 0,95 & 2,19 & 2,22 & 0,94 & 2,16 \\
\hline Matéria mineral, \% & 5,54 & 5,55 & 6,50 & 13,68 & 13,70 & 6,78 & 12,84 \\
\hline E.B.(kcal/kg) & $4.622,00$ & $4.765,00$ & $4.639,00$ & $5.027,00$ & $4.564,00$ & $4.922,00$ & $4.352,00$ \\
\hline Óxido de cromio & 0,49 & 0,32 & 0,46 & 0,47 & 0,47 & 0,51 & 0,50 \\
\hline
\end{tabular}

${ }^{\mathrm{a}}$ Composição dos ingredientes (g/100g MS):

- milho: proteína bruta 10,4; extrato etéreo, 4,21

- farinha de peixe importada: proteína bruta, 71,52; extrato etéreo, 13,22; índice de acidez, 5,53;

- farelo de soja: proteína bruta, 51,40; extrato etéreo, 6,71, uréase:0,03, solubilidade:80,93

- glúten de milho: proteína bruta, 71,24; extrato etéreo, 3,60

- farelo de trigo: proteína bruta, 17,12.

- sorgo: proteína bruta, 9,47; extrato etéreo, 2,65;

- farinha de peixe importada: proteína bruta, 71,52; extrato etéreo, 13,22; índice de acidez, 5,53;

- farinha de carne: proteína bruta, 41,19; extrato etéreo, 16,01; índice de acidez, 0,69;

- farinha de vísceras: proteína bruta, 61,79; extrato etéreo, 10,32; índice de acidez, 3,35;

- farinha de penas: proteína bruta, 80,28; extrato etéreo, 7,44; índice de acidez, 1,76.

b Suplementação/kg de ração: vitamina A 8.000 UI; vitamina B 4.000 UI; vitamina E 160 UI; vitamina K 4 $\mathrm{mg}$; vitamina C $320 \mathrm{mg}$; tiamina $10 \mathrm{mg}$; riboflavina $20 \mathrm{mg}$; piridoxina $15 \mathrm{mg}$; vitamina $\mathrm{B}_{12} 30 \mathrm{mcg}$; ácido pantotênico $40 \mathrm{mg}$; niacina $40 \mathrm{mg}$; ácido fólico $2 \mathrm{mg}$; biotina $900 \mathrm{mcg}$; colina $1.000 \mathrm{mg}$; Mn $30 \mathrm{mg}$; Zn 160 mg; Fe 110 mg; Cu 16 mg; I 0,6 mg; Se 0,6 mg. 
As determinações dos coeficientes de digestibilidade aparente (CDA, \%) da matéria seca $\left(\mathrm{CDA}_{\mathrm{MS}}\right)$, nutrientes $\left(\mathrm{CDA}_{\mathrm{N}}\right)$, e energia $\left(\mathrm{CDA}_{\mathrm{EB}}\right)$ das dietas experimentais foram realizadas pelo método indireto, utilizando como marcador inerte o óxido de cromio $\left(\mathrm{Cr}_{2} \mathrm{O}_{3}\right)$ (Burel et al., 2000; De Silva et al., 1997; De Silva \& Anderson, 1995), como segue:

$$
\begin{gathered}
C D A_{M S}=100 x\left[1-\left(\frac{\mathrm{Cr}_{2} \mathrm{O}_{3} \text { dieta }}{\mathrm{Cr}_{2} \mathrm{O}_{3} \text { fezes }}\right)\right] \\
C D A_{N / E B}=100 x\left[1-\left(\frac{\mathrm{Cr}_{2} \mathrm{O}_{3} \text { dieta }}{\mathrm{Cr}_{2} \mathrm{O}_{3} \text { fezes }}\right) \times\left(\frac{\text { nutriente ou energia fezes }}{\text { nutriente ou energia dieta }}\right)\right]
\end{gathered}
$$

Os valores das quatro repetições dos CDAs das diferentes dietas experimentais foram submetidos à análise de variância (ANOVA) e depois submetidos ao teste de comparação de médias Tukey $(\mathrm{P}=0,05)$ pelo aplicativo estatístico SAS (1985). 


\section{RESULTADOS E DISCUSSÃO}

As médias dos parâmetros de qualidade da água monitorados nos tanques de alimentação durante todo o período experimental foram: $\mathrm{pH} 7,5$; temperatura $27^{\circ} \mathrm{C} \pm$ $1,07^{\circ} \mathrm{C}$; oxigênio dissolvido $6,8 \pm 0,7 \mathrm{mg} / \mathrm{L}$; alcalinidade total $55 \mathrm{mg} / \mathrm{L}$; dureza total 87 $\mathrm{mg} / \mathrm{L}$ de equivalente $\mathrm{CaCO}_{3}$. Estas variações são consideradas estáveis e não exerceram qualquer influência nos resultados dos experimentos (Brune \& Tomasso, 1991).

O peso médio inicial dos peixes mostrou-se uniforme, não apresentando diferença siginificativa entre os tratamentos $(\mathrm{P}>0,05)$. Como já comentado, porque os resultados do primeiro ensaio apresentaram uma alta variação (Tabela 7), o ensaio foi repetido (Tabela 8). Como os peixes que consumiram as dietas contendo o atrativo "glicina" apresentaram diminuição no ganho de peso, este atrativo foi excluído do segundo ensaio para conclusão do experimento.

Não houve diferença entre os tratamentos $(\mathrm{P}>0,05)$ para todos os parâmetros analisados. Porém, uma análise gráfica mostrou os melhores parâmetros de desempenho para o tratamento contendo $0,02 \%$ de Fisharon $^{\circledR}$ (Figuras 1, 2 e 3). A maioria dos estudos com atrativos é conduzida em intervalo de tempo relativamente curto, uma vez que estes parecem perder o efeito estimulatório quando fornecido por períodos prolongados. Entretanto, estas observações mostram que seria importante realizar estudos prolongados, que poderiam representar melhor o efeito do atrativo, simulando condições da criação comercial de peixes. Vários autores enfatizam que a viabilidade financeira do uso de atrativos alimentares é ainda questionável, mas pode vir a ser uma necessidade em um futuro próximo, especialmente em casos onde a substituição da 
farinha de peixe se tornar prática corrente em resposta a considerações ecológicas (Papatryphon \& Soares Jr, 2000b).

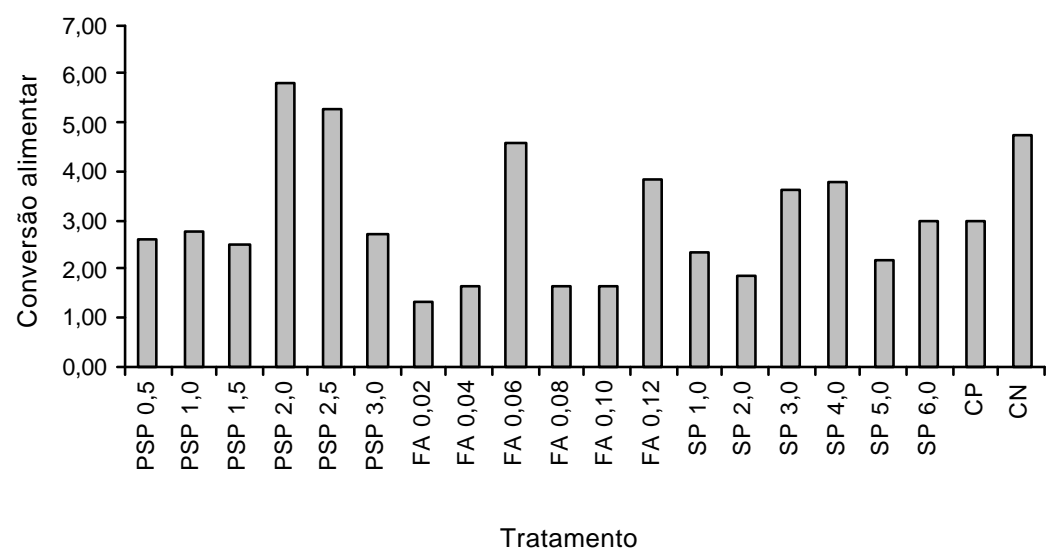

Figura 1 - Conversão alimentar de juvenis de black bass alimentados com dietas contendo diferentes fontes e níveis de atrativos

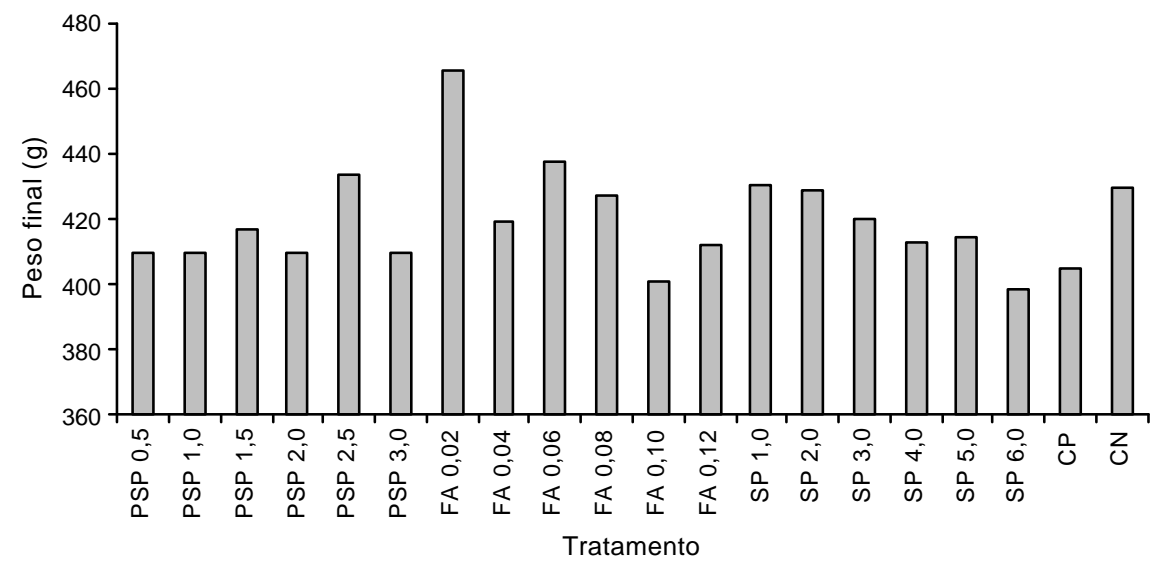

Figura 2 - Peso final de juvenis de black bass alimentados com dietas contendo diferentes fontes e níveis de atrativos 


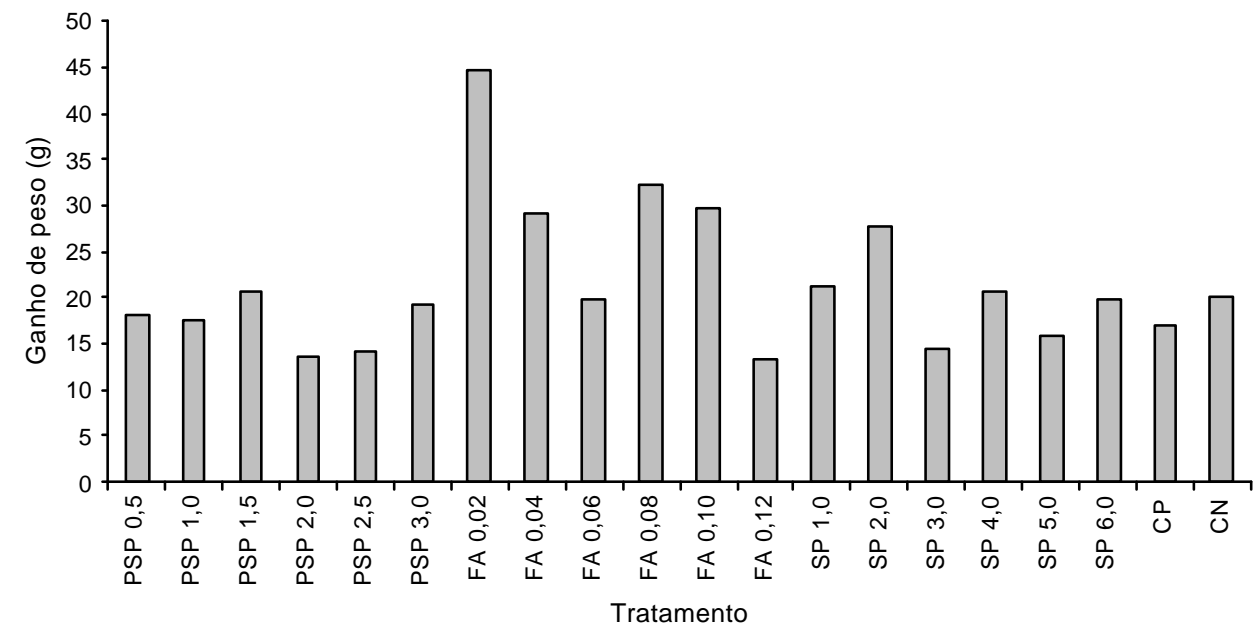

Figura 3 - Ganho de peso de juvenis de black bass alimentados com dietas contendo diferentes fontes e níveis de atrativos 
Tabela 7.Peso inicial (PI), peso final (PF), ganho de peso (GP), consumo ração (CR) e conversão alimentar (CA) de juvenis de black bass alimentados com dietas contendo diferentes tipos e níveis de atrativos

\begin{tabular}{|c|c|c|c|c|c|c|c|c|c|c|c|c|c|}
\hline \multirow[b]{2}{*}{ Desempenho } & \multicolumn{13}{|c|}{ Dieta } \\
\hline & G $0,5 \%$ & G $1,0 \%$ & G $1,5 \%$ & G $2,0 \%$ & G $2,5 \%$ & G3,0\% & PSP $0,5 \%$ & PSP $1,0 \%$ & PSP $1,5 \%$ & PSP 2,05 & PSP 2,5\% & PSP $3,0 \%$ & FA $0,02 \%$ \\
\hline $\mathrm{PI}, \mathrm{g}$ & 381,16 & 363,63 & 373,67 & 366,67 & 353,93 & 373,84 & 373,82 & 362,90 & 369,79 & 375,25 & 373,10 & 356,70 & 360,56 \\
\hline $\mathrm{GP}, \mathrm{g}$ & $-2,57$ & 1,91 & $-9,32$ & $-7,66$ & $-4,73$ & $-5,66$ & 7,06 & 8,77 & 5,85 & $-9,33$ & $-0,81$ & 4,38 & 2,58 \\
\hline $\mathrm{CR}, \mathrm{g}$ & 19,64 & 21,49 & 17,81 & 18,25 & 18,67 & 19,42 & 19,80 & 22,35 & 20,07 & 20,58 & 21,61 & 23,25 & 21,12 \\
\hline $\mathrm{PI}, \mathrm{g}$ & 349,81 & 361,69 & 365,31 & 386,06 & 353,78 & 370,67 & 371,65 & 369,83 & 357,52 & 365,43 & 390,89 & 364,54 & 355,09 \\
\hline$P F, g$ & 354,57 & 367,21 & 369,76 & 386,96 & 357,89 & 372,57 & 378,37 & 373,78 & 360,23 & 367,66 & 392,14 & 365,97 & 370,07 \\
\hline $\mathrm{GP}, \mathrm{g}$ & 4,75 & 5,52 & 4,45 & 0,90 & 4,10 & 1,90 & 6,72 & 3,96 & 2,71 & 2,24 & 1,25 & 1,42 & 14,98 \\
\hline $\mathrm{CR}, \mathrm{g}$ & 20,52 & 21,33 & 20,64 & 19,11 & 21,18 & 19,65 & 20,30 & 21,45 & 22,96 & 20,32 & 23,59 & 22,77 & 22,47 \\
\hline
\end{tabular}


Tabela 8.Peso inicial (PI), peso final (PF), ganho de peso (GP), consumo de ração (CR) e conversão alimentar (CA) de juvenis de black bass alimentados com dietas contendo diferentes tipos e níveis de atrativos

\begin{tabular}{lcccccccccc}
\hline & \multicolumn{1}{c}{ Dieta } \\
\cline { 2 - 11 } Desempenho & PSP 0,5\% & PSP 1,0\% & PSP 1,5\% & PSP 2,0\% & PSP 2,5\% & PSP 3,0\% & FA 0,02\% & FA 0,04\% & FA 0,06\% & FA 0,08\% \\
\hline PI, g & 392,05 & 392,38 & 395,74 & 396,18 & 419,30 & 390,77 & 420,53 & 389,91 & 418,18 & 394,89 \\
PF, g & 410,09 & 409,80 & 416,54 & 409,65 & 433,38 & 409,99 & 465,21 & 419,03 & 437,90 & 426,99 \\
GP, g & 18,03 & 17,42 & 20,80 & 13,47 & 14,08 & 19,21 & 44,68 & 29,12 & 19,72 & 32,11 \\
CR, g & 46,33 & 45,03 & 50,57 & 49,15 & 44,62 & 47,40 & 52,53 & 45,05 & 48,16 & 50,43 \\
CA,g & 2,57 & 2,58 & 2,43 & 5,79 & 3,65 & 3,17 & 2,47 & 1,17 & 2,44 & 1,57 \\
\hline Desempenho & FA0,10\% & FA0,12\% & SP 1,0\% & SP 2,0\% & SP 3,0\% & SP 4,0\% & SP 5,0\% & SP 6,0\% & CP 10\%FP CN100\%PV \\
\hline PI, g & 370,99 & 398,77 & 409,52 & 401,58 & 405,89 & 392,16 & 398,53 & 378,64 & 387,49 & 409,59 \\
PF, g & 400,59 & 412,04 & 430,71 & 429,28 & 420,19 & 412,82 & 414,30 & 398,43 & 404,59 & 429,70 \\
GP, g & 29,60 & 13,28 & 21,19 & 27,70 & 14,30 & 20,67 & 15,77 & 19,79 & 17,10 & 20,11 \\
CR, g & 48,32 & 47,07 & 48,11 & 49,15 & 45,42 & 47,55 & 45,69 & 46,23 & 46,16 & 45,77 \\
CA,g & 1,63 & 3,54 & 2,27 & 1,77 & 3,18 & 2,30 & 2,89 & 2,34 & 3,00 & 2,28 \\
\hline
\end{tabular}


Já foi demonstrado que a glicina é um bom atrativo para várias espécies, como para o "sea bream" (Fuke et al., 1981; Shimizu et al., 1990) e o salmão "Chinook" (Hughes, 1985). Entretanto, este aminoácido não estimulou com eficiência o consumo de alimento pelos juvenis de black bass no presente estudo. Segundo McGoogan \& Reigh (1996), o "red drum" é capaz de utilizar dietas com até $80 \%$ da proteína originária do farelo de soja com suplementação de glicina e $20 \%$ da farinha de peixe sem redução significativa no ganho de peso, quando comparado a uma dieta contendo apenas proteína originária da farinha de peixe. Resultados de investigações sobre o uso de substâncias que estimulam o consumo de alimento pelos peixes, sugerem que embora o sabor de um alimento seja quimicamente mediado por substâncias inerentes ao alimento, a quimiossensitividade da espécie ainda desempenha um papel regulatório na ingestão deste alimento (Adams et al., 1988).

O valor nutritivo da silagem está na sua digestibilidade protéica, que deve ser preservada, evitando-se uma estocagem prolongada. Em comparação à farinha de peixe, a silagem apresenta teores mais baixos de aminoácidos sulfurados, porém mais elevados em lisina (Arruda et al., 2001).

Papatryphon \& Soares Jr. (2000a) consideraram os aminoácidos neutros não essenciais (alanina, serina, glicina e prolina) como os mais efetivos atrativos alimentares para o "striped bass". A suplementação de $2 \%$ de solúveis de peixe resultou em significativo aumento do consumo de alimento pelo "striped bass", aproximando do efeito dos aminoácidos neutros não essenciais. Porém, para o "red drum", a suplementação de $2 \%$ de solúveis de peixes em rações formuladas à base de farinha de peixe, não apresentou efeito benéfico no desenvolvimento (Davis et al., 1995). Por outro lado, $2 \%$ ou $4 \%$ de suplementação aumentou o consumo de alimento pelo "red drum" alimentado com ração formulada à base de farelo de soja (McGoogan \& Gatlin, 1997).

A proteína hidrolisada de peixe (PHP), ingrediente utilizado em rações como suplemento protéico e atrativo em potencial, tem induzido aumento no crescimento e na utilização de alimento em salmonídeos (Berge \& Storebakken, 1996; Carvalho et al., 1997). Este efeito positivo pode ser atribuído ao aumento da digestiblidade da proteína devido ao tratamento enzimático, que inicia a degradação das proteínas e fornece 
peptídeos de cadeia curta e aminoácidos livres que podem também funcionar como atrativos para algumas espécies, aumentando crescimento e utilização do alimento. Testando a utilização de altos níveis de proteína hidrolisada $(5,15$ e $25 \%)$ para juvenis de "turbot", Oliva-Teles et al. (1999) observaram que a inclusão da proteína hidrolisada em substituição a uma determinada fração da farinha de peixe, não melhorou os índices de desempenho dos peixes. Segundo Cahu et al. (1999), algumas enzimas envolvidas na hidrólise da proteína e que atuam em diferentes fases da digestão são responsáveis pelos efeitos reduzidos da proteína hidrolisada de peixe como atrativo da ingestão.

O nível de secreção da tripsina foi maior para os tratamentos sem e com 19\% de PHP, que para os tratamentos contendo 38 e 58\% de PHP. O nível maior de PHP na dieta pode ter produzido uma "explosão" de nutrientes - aminoácidos e peptídeos - no intestino, induzindo uma saturação nos mecanismos de transporte. Isto pode explicar, em parte, os efeitos negativos de altos níveis dietéticos de PHP. No presente experimento, as quantidades utilizadas da proteína solúvel de peixe foram bem menores $(0,5$ a 3,0\%) e possivelmente podem não ter sido suficientes para apresentar algum resultado diferenciado entre os tratamentos.

Segundo Xue \& Cui (2001), algumas substâncias presentes na farinha de peixe, provavelmente atuam com atrativos. Na dieta contendo farinha de carne e ossos, mesmo com reduzida quantidade de farinha de peixe, o efeito do atrativo foi menor. A farinha de carne e ossos pode ter exercido algum efeito deletério e, conseqüentemente, os peixes tornaram-se sensíveis à adição de atrativos. Segundo Kubitza et al. (1997), o IMP-5', encontrado em abundância em músculos de peixes e consequentemente na farinha de peixe, é o nutriente que apresenta melhor efeito estimulatório no consumo de alimento.

Em relação aos Experimentos 2 e 3, as médias de peso final (PF), ganho de peso (GP), consumo de ração (CR), conversão alimentar (CA) e taxa de eficiência protéica (TEP), diferiram entre os tratamentos $(\mathrm{P}<0,05)$. Os tratamentos 60PV:40PA, controle e 50PV:50PA, apresentaram os maiores valores para ganho de peso e peso final; não apresentaram diferenças entre si $(\mathrm{P}>0,05)$ mas diferiram $(\mathrm{P}<0,05)$ dos tratamentos 100PV:0PA, 100PV+A; 80PV:20PA e 40PV:60PA que, outra vez, não diferiram entre si $(\mathrm{P}>0,05)$ (Tabela 9$)$. 
$\mathrm{O}$ ganho de peso dos black bass de 3,05 g a 11,20 g variou de 0,15 a 0,22 g/dia (Figuras 4 e 5), mantendo-se um pouco abaixo do observado por Portz (2001) para a mesma espécie $(0,28 \mathrm{~g} / \mathrm{dia})$; entretanto, este autor utilizou peixes de peso inicial maior (21 g). Valores comumente observados para ganho de peso em produções comerciais estão em torno de 0,4 g para o bagre do canal; 0,5 g para o tambaqui Colossoma macropomum; 0,6 g para Brycon sp; 0,6 g para a tilápia do Nilo Oreochromis niloticus; 0,5 g para carpa comum Cyprinus carpio; 0,5 g para o pacu Piaractus mesopotamicus; 0,7 a 0,9 g para o pintado Pseudoplatystoma coruscans; e 0,315 g/dia para o tucunaré Cichla sp. (Sampaio, 1998).

Webster et al. (1997) observaram que a palatabilidade de dietas para peixes carnívoros influencia muito o consumo alimentar e pode afetar o desempenho dos peixes, o que é corroborado pelos resultados deste experimento: melhores resultados de ganho de peso foram observados para o controle do que para o tratamento 50PV:50PA, que continham em sua composição óleo de peixe (2,08\%), farinha de vísceras (15\%) e farinha de peixe $(5 \%)$.

Os melhores valores de CA foram associados ao tratamento 80PV:20PA, porém não houve diferença significativa $(\mathrm{P}>0,05)$ entre o 100PV+A $(1,18), 80 \mathrm{PV}: 20 \mathrm{PA}$ $(1,10)$ e o controle (1,17). Entretanto, estes tratamentos diferiram $(\mathrm{P}<0,05)$ dos 100PV:0PA (1,25), 60PV:40PA (1,22), 40PV:60PA (1,23) e 50PV:50PA (1,27); 100PV:0PA, 100PV+A, 60PV:40PA, 40PV:60PA, controle e 50PV:50PA também não apresentaram diferenças entre si $(\mathrm{P}>0,05)$. Todos os tratamentos apresentaram bons índices de conversão alimentar, que variaram de 1,10 a 1,27. Estes resultados podem ser atribuídos às boas condições de qualidade de água nas unidades experimentais, ao bom manejo alimentar e àboa qualidade das dietas experimentais. 
Tabela 9 Peso inicial (PI), peso final (PF), ganho de peso (GP), consumo ração (CR), conversão alimentar (CA), taxa de eficiência protéica (TEP), relação hepatosomática (RHS), retenção de energia (RE), retenção de proteína (RP), glicogênio no músculo (GM), glicogênio no fígado (GF), composição do fígado e da carcaça (matéria seca) de juvenis de black bass, alimentados com dietas contendo diferentes proporções de proteína animal e vegetal

\begin{tabular}{|c|c|c|c|c|c|c|c|}
\hline \multirow[b]{2}{*}{ Desempenho } & \multicolumn{7}{|c|}{ Dieta } \\
\hline & 10OPV:OPA & $100 \mathrm{PV}+\mathrm{A}$ & 8OPVZOPA & 60PV:40PA & 40PVI6OPA & Controle & 5OPV50PA \\
\hline $\mathrm{PI}, \mathrm{g}$ & 62,98 & 62,43 & 55,08 & 59,47 & 61,18 & 61,97 & 65,04 \\
\hline $\mathrm{PF}, \mathrm{g}$ & $194,04^{b}$ & $193,99^{b}$ & $209,88^{\mathrm{ab}}$ & $242,27^{a}$ & $227,83^{\mathrm{ab}}$ & $248,82^{a}$ & $251,88^{a}$ \\
\hline GP, $g$ & $131,05^{b}$ & $131,56^{b}$ & $154,81^{\mathrm{ab}}$ & $182,80^{\mathrm{a}}$ & $166,65^{\mathrm{ab}}$ & $186,86^{\mathrm{a}}$ & $186,84^{a}$ \\
\hline $\mathrm{CR}, \mathrm{g}$ & $163,05^{\mathrm{c}}$ & $155,48^{\mathrm{c}}$ & $170,51^{\mathrm{bc}}$ & $221,94^{\mathrm{a}}$ & $205,13^{\mathrm{ab}}$ & $218,17^{\mathrm{a}}$ & $236,78^{a}$ \\
\hline $\mathrm{CA}, \mathrm{g}$ & $1,25^{\mathrm{b}}$ & $1,18^{\mathrm{ab}}$ & $1,10^{\mathrm{a}}$ & $1,22^{b}$ & $1,23^{b}$ & $1,17^{\mathrm{ab}}$ & $1,27^{b}$ \\
\hline TEP, \% & $1,92^{\mathrm{c}}$ & $1,99^{b c}$ & $2,17^{a}$ & $1,99^{b c}$ & $1,98^{\mathrm{bc}}$ & $2,15^{\mathrm{ab}}$ & $1,96^{c}$ \\
\hline \multicolumn{8}{|c|}{ Retenção em nutrientes } \\
\hline GF mg $100 \mathrm{mg}^{-1}$ & 4,10 & 3,97 & 4,10 & 4,50 & 4,85 & 3,90 & 3,54 \\
\hline $\mathrm{GM} m g$ 100 $\mathrm{mg}^{-1}$ & 0,47 & 0,57 & 0,40 & 0,42 & 0,51 & 0,58 & 0,38 \\
\hline RHP, \% & 1,465 & 1,442 & 1,780 & 1,710 & 2,632 & 2,425 & 2,360 \\
\hline $\mathrm{RE}, \%$ & $22,59^{b}$ & $23,82^{b}$ & $26,22^{a}$ & $25,84^{\mathrm{a}}$ & $27,33^{\mathrm{a}}$ & $23,02^{b}$ & $27,69^{a}$ \\
\hline $\mathrm{RP}, \%$ & $28,98^{a}$ & $28,65^{\mathrm{cd}}$ & $31,95^{b}$ & $26,78^{d}$ & $28,42^{\mathrm{cd}}$ & $31,45^{\mathrm{bc}}$ & $28,00^{d}$ \\
\hline \multicolumn{8}{|c|}{ Composição do fígado } \\
\hline Umidade, \% & 73,72 & 72,19 & 71,14 & 72,69 & 69,09 & 69,94 & 69,26 \\
\hline Proteína bruta, \% & 39,70 & 39,34 & 32,94 & 40,73 & 25,92 & 29,03 & 27,38 \\
\hline Extrato etéreo, \% & 7,87 & 9,68 & 2,47 & 3,84 & 0,68 & 1,40 & 1,36 \\
\hline \multicolumn{8}{|c|}{ Composição Corporal } \\
\hline Umidade, \% & 73,83 & 75,38 & 74,12 & 74,64 & 73,59 & 73,83 & 73,48 \\
\hline Proteína Bruta, \% & 56,13 & 57,70 & 55,82 & 53,35 & 53,67 & 55,14 & 53,46 \\
\hline Extrato etéreo, \% & 20,8 & 19,58 & 24,64 & 27,24 & 20,02 & 13,06 & 17,14 \\
\hline Matéria Mineral, \% & 15,12 & 12,55 & 12,01 & 10,37 & 10,17 & 15,72 & 12,44 \\
\hline Fibra Bruta, \% & 0,25 & 0,71 & 0,71 & 0,54 & 0,32 & 0,51 & 0,30 \\
\hline E.B.,kcal/kg & $5.039,00$ & $5.367,00$ & $5.259,00$ & $5.513,00$ & $5.429,00$ & $4.881,00$ & $5.188,00$ \\
\hline
\end{tabular}

Para cada variável, dietas seguidas da mesma letra não diferem entre si pelo teste de Tukey $(\mathrm{P} \leq 0,05)$. 


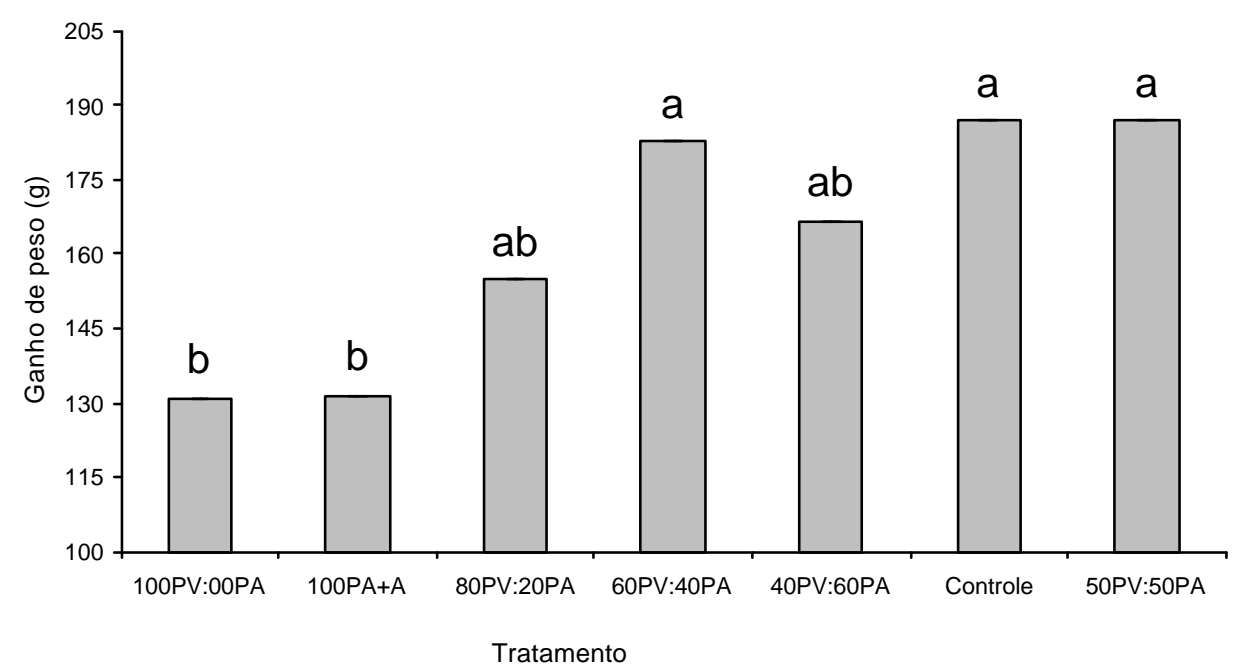

Figura 4 - Ganho de peso de juvenis de black bass alimentados com dietas contendo diferentes proporções de proteína animal e vegetal

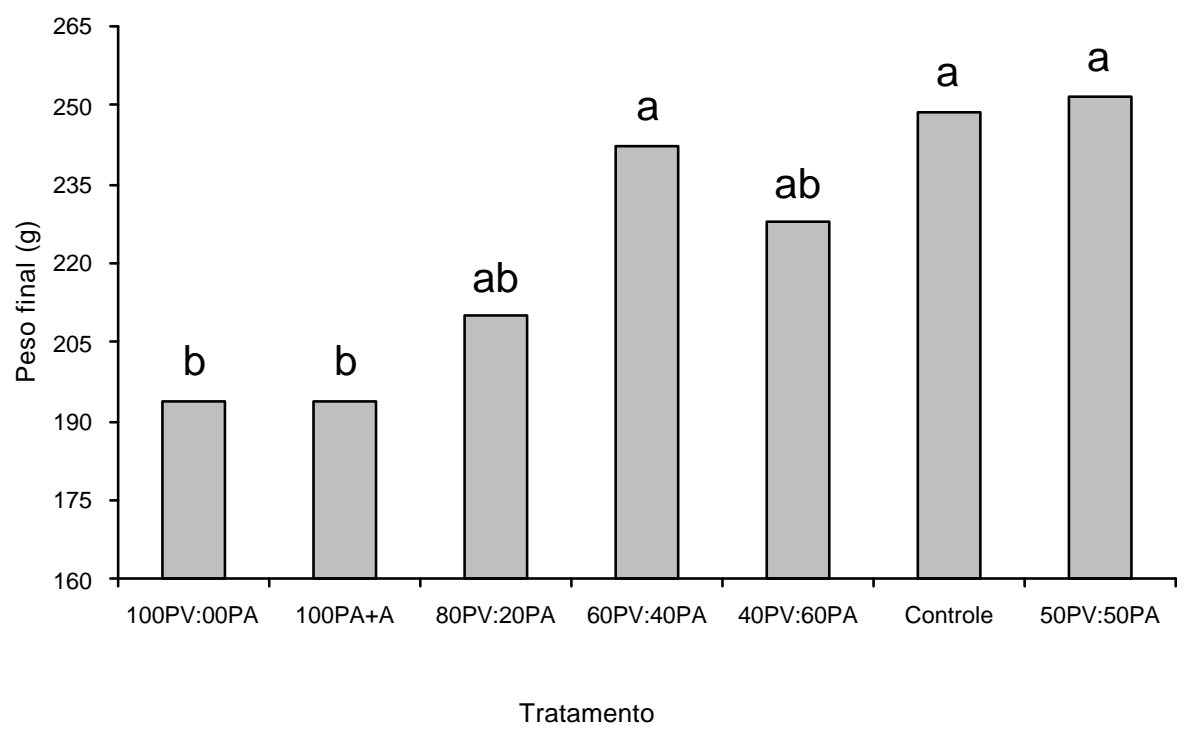

Figura 5 - Peso final de juvenis de black bass alimentados com dietas contendo diferentes proporções de proteína animal e vegetal 
A suplementação de lisina e metionina em dietas para o black bass pode melhorar a conversão alimentar e as características da composição corporal da espécie (Coyle et al, 2000). A lisina é o aminoácido mais limitante em dietas para peixes e sua deficiência normalmente pode reduzir o crescimento e piorar os valores de conversão alimentar (Wilson, 1991). A metionina é um importante doador de grupamento metil e os níveis de exigência para peixes são apresentados de acordo com as concentrações de cistina na dieta, podendo este último ser substituído por uma porção de quantidades não exigidas pelo peixe (De Silva \& Anderson, 1995). No presente estudo foi necessário suplementar lisina e metionina sintéticas nos tratamentos que apresentaram maiores inclusões de proteína vegetal e que se mostraram deficientes neste aminoácido. Todas as dietas apresentaram em sua composição níveis semelhantes destes aminoácidos, estimados com base na matriz do programa de formulação.

Segundo Lovell (1989) a inclusão de aminoácidos sintéticos em uma dieta aumenta os custos de produção, mas melhora substancialmente os valores de conversão alimentar. A piora na conversão alimentar pode ser um indicativo da deficiência em aminoácidos (Wilson, 1991). No presente estudo, uma vez que as dietas eram isonitrogenadas e isocalóricas, todas as diferenças observadas, tanto em relação ao desempenho como em relaçãoo à composição corporal dos animais, podem ser atribuídos às diferentes proporções ou combinações de cada ingrediente na dieta.

Em relação às médias de consumo de ração (CR) (Figura 6), não houve diferença $(\mathrm{P}>0,05)$ entre 60PV:40PA (221,94 g), 40PV:60PA (205,13 g), controle (218,17 g) e 50PV:50PA (236,78 g), nem entre 80PV:20PA (170,51 g) e 40PV:60PA $(205,13 \mathrm{~g})$, assim como entre 100PV:0PA (163,05 g), 100PV+A (155,48 g) e 80PV:20PA (170,51 g). Porém, estes grupos apresentaram diferenças entre si $(\mathrm{P}<0,05)$. A diferença observada no consumo de ração entre os tratamentos pode ter sido causada pela menor palatabilidade das dietas que continham menores concentrações de proteína animal. Embora não tenham sido observadas diferenças entre 60PV:40PA, 40PV:60PA, controle e 50PV:50PA, os peixes apresentaram um decréscimo no consumo de ração conforme aumentou a relação ED:PB. 


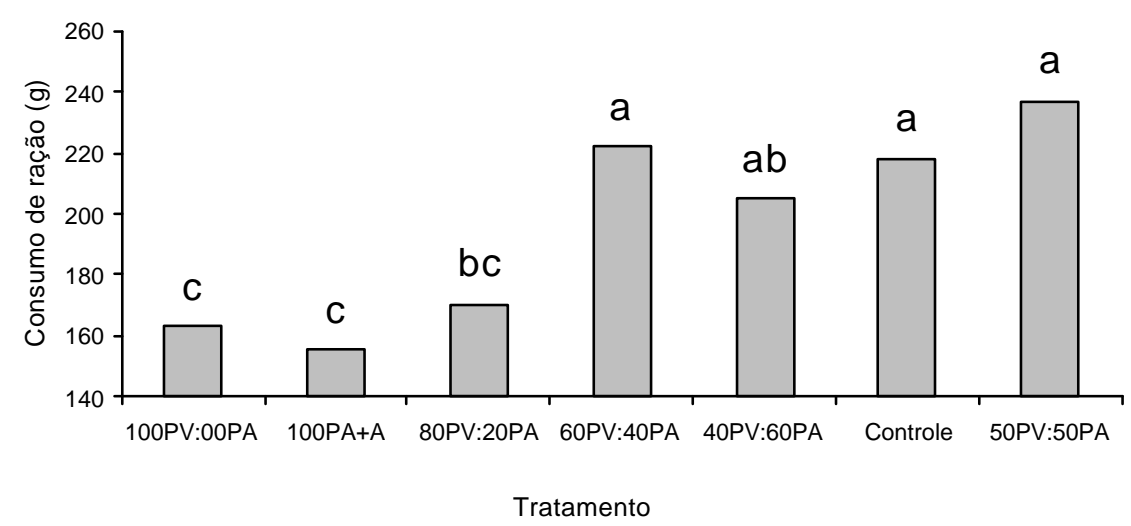

Figura 6 - Consumo de ração de juvenis de black bass alimentados com dietas contendo diferentes proporções de proteína animal e vegetal

Trabalhos realizados por Page \& Andrews (1973), testando vários níveis de energia e proteína na dieta para o bagre do canal, mostraram que o consumo de ração diminuiu conforme aumentaram os níveis de energia dietética, levando à conclusão que os peixes se alimentam para satisfazer suas necessidades em energia. Para os níveis de proteína estudados ( 25 e 35\%), os autores observaram uma diminuição no consumo de ração conforme aumentaram os níveis de gordura nas dietas. Entretanto não foram observadas diferenças no consumo de ração em outras dietas com o mesmo nível de proteína e com níveis diferentes de energia. Os autores sugeriram, então, que o consumo de alimento também pode ser influenciado pelo nível de proteína na dieta.

A suplementação de dietas com lisina e metionina sintéticas, possibilita produzir uma dieta para a truta arco-ŕris baseada exclusivamente em farinha de vísceras (Nengas et al., 1999). Bureau et al. (2000) testaram farinha de vísceras e de carne e ossos de diferentes origens para a truta arco-íris e observaram que a farinha de vísceras pode substituir $15 \%$ da farinha de peixes na dieta sem afetar o crescimento, eficiência alimentar e função osmorregulatória dos peixes. A diminuição no crescimento de peixes alimentados com dieta contendo $20 \%$ de farinha de vísceras pode ser atribuída à deficiência de lisina ou outros aminoácidos. Segundo Fowler (1991), a farinha de 
vísceras pode substituir a farinha de peixe em dietas para os salmões do Pacífico e “chinook" em níveis de até $20 \%$. Entretanto, em níveis de 30\%, reduz o crescimento provavelmente em função da redução da palatabilidade (Webster et al., 2000). De fato, Monhsen \& Lovell (1990) citam que a inclusão da farinha de carne e ossos em níveis de $11 \%$ aumenta a palatabilidade das dietas. Por outro lado, Stone et al. (2000) avaliaram a substituição da farinha de peixe pela farinha de carne em dietas para a perca australiana e observaram que os nutrientes e energia foram bem digeridos quando os peixes foram alimentados com dietas contendo até $30 \%$ de farinha de carne.

A TEP foi maior para 80PV:20PA $(2,17)$ e controle $(2,15)$, que diferiram dos demais $(\mathrm{P}<0,05)$ (Figura 7); 100PV+A $(1,99)$, 60PV:40PA $(1,99)$ e 40PV:60PA $(1,98)$ não apresentaram diferença $(\mathrm{P}>0,05)$. A taxa de eficiência protéica neste estudo variou de 1,92 (100PV:0PA) a 2,17 (80PV:20PA).

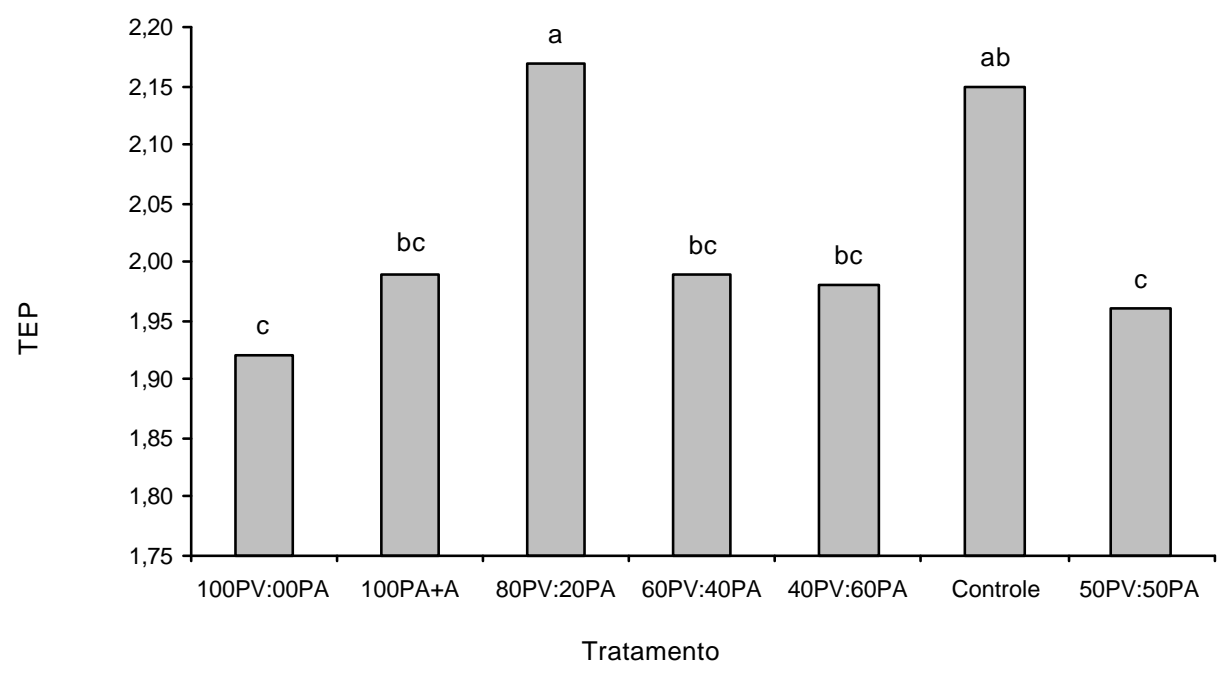

Figura 7 - Taxa de eficiência protéica de juvenis de black bass alimentados com dietas contendo diferentes proporções de proteína animal e vegetal

Os resultados dos índices de desempenho menos expressivos estão relacionados aos tratamentos 100PV:0PA e 100PV+A. Watanabe et al. (1997) consideram que pesquisas relacionadas à substituição da farinha de peixe por combinações de diferentes fontes de proteína são muito oportunas. A inclusão de altos níveis de uma determinada 
fonte de proteína de origem vegetal pode exacerbar problemas, não só relacionados ao balanço de aminoácidos essenciais, mas também relacionados aos possíveis efeitos dos fatores antinutricionais. Um exemplo é o trabalho de Regost et al. (1999), que utilizando $57 \%$ de glúten de milho na dieta do "turbot" observaram redução na digestibilidade aparente dos aminoácidos da dieta e redução no crescimento. Porém, Pezzato (2002) relata alguns estudos que têm demonstrado melhora no crescimento de peixes, mesmo carnívoros, alimentados com dietas à base de farelo de soja, suplementadas com aminoácidos - metionina, leucina, lisina, valina, treonina e triptofano.

Foram observadas diferenças significativas $(\mathrm{P}<0,05)$ nas taxas de retenção de nutrientes para proteína e energia. As melhores taxas de retenção protéica foram relacionadas aos tratamentos 80PV:20PA (31,95) e controle (31,45\%). Existe uma relação característica entre o nível de proteína da dieta e a utilização da proteína pelo peixe: quando a dieta apresenta baixos níveis de energia, a utlização de proteína é baixa; conforme o nível de proteína aumenta, a utilização de proteína também aumenta e alcança um máximo perto do nível mínimo de proteína exigido; em níveis de proteína além do mínimo exigido, a utilização de proteína diminui (Figura 8).

Os valores de retenção energética variaram de $22,59 \%$ no tratamento 100PV:0PA a 27,69\% no tratamento 50PV:50PA; houve uma tendência de aumento na retenção de energia com o aumento da proporção de proteína animal na dieta. Apenas o tratamento controle apresentou uma diminuição no valor de retenção de energia. Não foram observadas diferenças significativas $(\mathrm{P}>0,05)$ entre os tratamentos 80PV:20PA (26,22), 60PV:40PA (25,84), 40PV:60PA (27,33) e 50PV:50PA $(27,69)$, e entre 100PV:0PA $(22,59), 100 \mathrm{PV}+\mathrm{A}(23,82)$ e controle $(23,02)$. Porém estes grupos diferiram entre si $(\mathrm{P}<0,05)$ (Figura 9). 


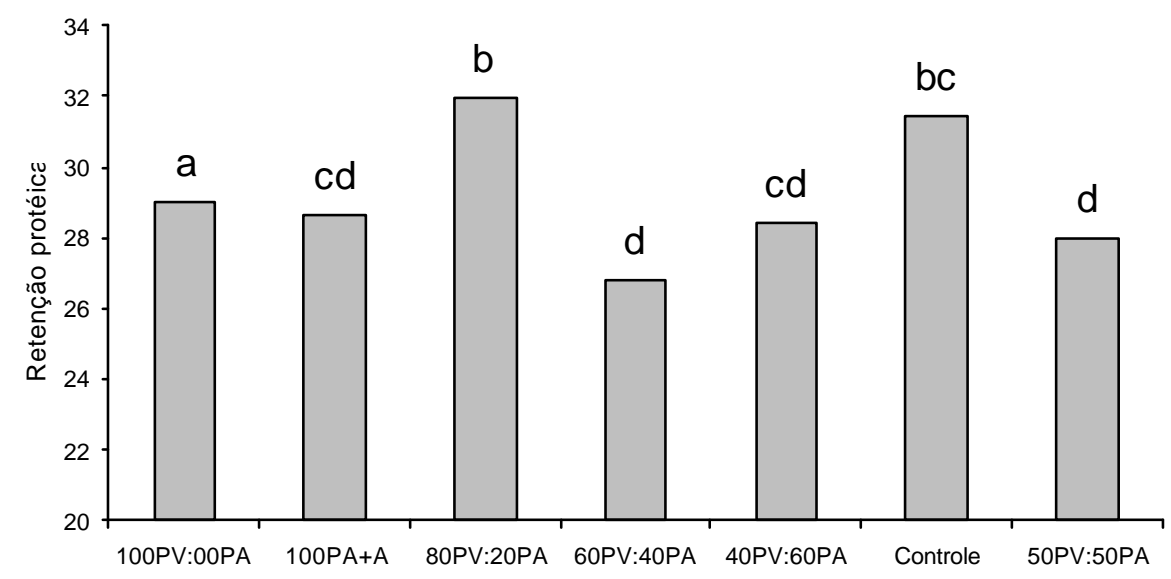

Tratamento

Figura 8 - Retenção protéica em juvenis de black bass alimentados com dietas contendo diferentes proporções de proteína animal e vegetal

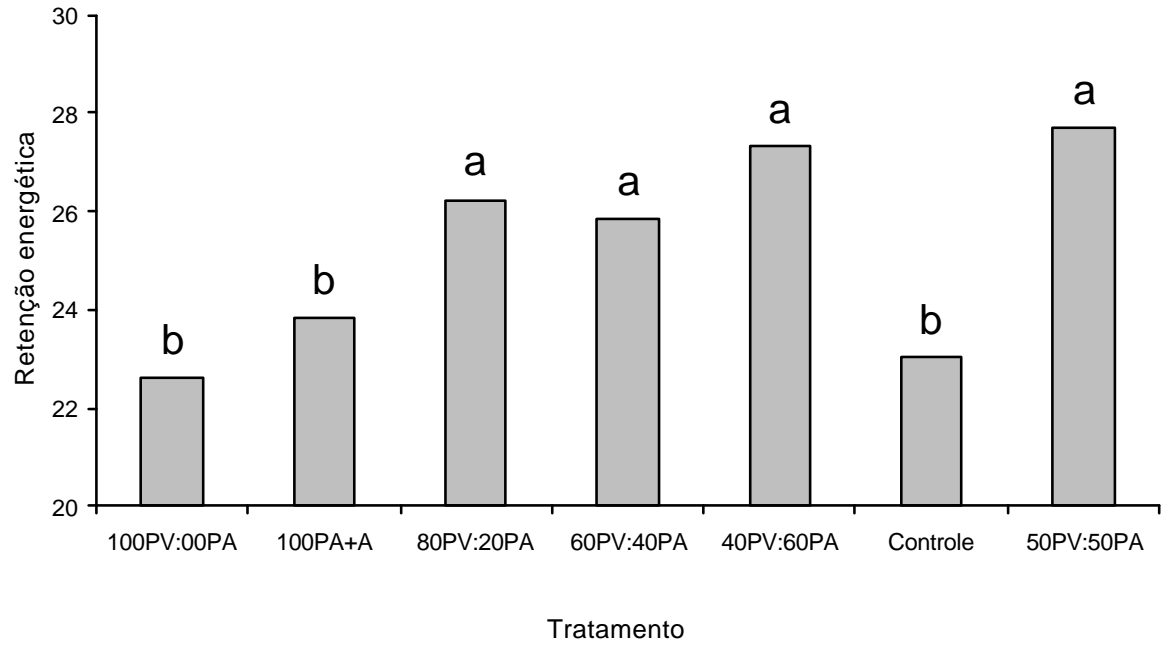

Figura 9 - Retenção energética em juvenis de black bass alimentados com dietas contendo diferentes proporções de proteína animal e vegetal 
De acordo com Bromley (1980) a eficiência de conversão de energia não é influenciada pela sua concentração na ração. Em outras palavras, o total de energia depositado nos peixes depende do total de energia consumido e não é afetado pela proporção de proteína e lipídios na dieta. Em dietas com altos teores de lipídio, menos energia é depositada na forma de proteína e proporcionalmente mais energia é depositada como gordura, ou seja, como reserva corporal (Lee \& Putnam, 1973; Page \& Andrews, 1973; Adron et al., 1976). As reservas de lipídio estão acumuladas em forma concentrada, mas a proteína está diluída na água do citosol. Uma unidade de energia depositada na forma de proteína é acompanhada por um aumento no peso de aproximadamente oito vezes, quando associado a similar quantidade de energia depositada como gordura. Isso explica porque o crescimento em peso é reduzido em dietas contendo altos teores de lipídio. A prática da adição de lipídios às dietas para conservar a proteína deve ser revista com cuidado, pois pode resultar em crescimento reduzido e altos níveis de deposição de gordura visceral, como demonstrado por Bromley (1980) para o "turbot".

A variação da composição corporal observada neste trabalho, assim como os valores de RP\%, RE\% e TEP, são semelhantes àqueles encontrados por Kubitza (1990) para o pacu, por Sampaio (1998) com dietas contendo diferentes relações ED:PB para o tucunaré, por Portz (1999), com dietas contendo diferentes relações ED:PB para o black bass e Portz (2001) com substituição da farinha de peixe pela farinha de vísceras para o black bass. O conteúdo de proteína variou de 53,35\% (60PV:40PA) a 57,70\% (100PV+A), enquanto que o conteúdo de lipídios oscilou de $13,06 \%$ (controle) a 27,24\% (60PV:40PA).

Segundo Garling \& Wilson (1976) em geral um aumento na concentração de lipídios condiciona uma diminuição na porcentagem de água, proteína e cinzas na carcaça. Segundo Takeuchi (1997), os lipídios são fonte de energia e de ácidos graxos essenciais, precursores de hormônios esteróides e prostaglandinas, bem como veículos para absorção de vitaminas lipossolúveis. Verifica-se, porém, que altos teores de gordura no alimento reduzem rendimento de carcaça, qualidade do pescado e tempo de 
armazenamento dos produtos processados. A utilização de energia por peixes carnívoros tende a ser negativamente relacionada ao conteúdo de carboidrato e positivamente relacionada ao conteúdo de lipídios e proteína na dieta. Estima-se que dietas naturais para carnívoros contenham $50 \%$ de proteína e $50 \%$ de gordura em relação ao peso seco (Sullivan \& Reigh, 1995).

A proteína é responsável pela maior parte do custo de uma ração (Robinson \& Li, 1997). Se o teor de energia de uma dieta não for suficiente, ou se a proteína for de baixa qualidade, ela será deaminada no corpo para ser utilizada como fonte de energia para o metabolismo. Uma baixa relação energia:proteína pode reduzir a taxa de crescimento devido ao aumento da demanda metabólica para excreção de nitrogênio. Excesso de energia na ração pode causar deposição excessiva de gordura nos peixes, reduzir consumo de alimento (reduzindo a ingestão de proteína total) e inibir a utilização de outros nutrientes (Cho, 1990).

Uma dieta deficiente em energia em relação à proteína condicionará o uso da proteína dietética como energia para manutenção e não para crescimento. Em contraste, uma dieta contendo excesso de energia pode reduzir consumo de alimento e deste modo, diminuir a ingestão de proteína e outros nutrientes essenciais necessários para máximo crescimento. Um excesso de energia dietética em relação a outros nutrientes pode levar a grandes acúmulos de gordura corporal, indesejáveis em peixes de mesa (Bromley, 1980; NRC, 1993; Winfree \& Stickney, 1981). As necessidades em energia digestível para máximo ganho de peso foram determinadas para várias espécies, como por exemplo, para o bagre do canal (600g) em 3.000; para o "red drum" (43g) em 3.200; para a tilápia do Nilo (50g) em 2.900; para carpa comum (20g) em 2.900 e para truta arco-íris $(90 \mathrm{~g})$ em $3.600 \mathrm{kcal} / \mathrm{kg}$ (Daniels \& Robinson, 1986; Garling \& Wilson, 1976; Li \& Lovell, 1992 a,b; NRC, 1993). Estes autores são unânimes em afirmar que estas variações são ocasionadas pelos diferentes hábitos alimentares destes peixes.

Lee \& Putnam (1973) em estudos com a truta arco-íris concluíram que o consumo de alimento pela truta foi regulado pelo conteúdo de calorias na ração e que a utilização da proteína e a taxa de retenção da proteína consumida aumentaram conforme aumentaram os níveis de amido, indicando que existe um efeito economizador da 
proteína pelo amido. Os peixes alimentados com dietas contendo baixa energia foram capazes de ganhar peso em taxas comparáveis àquelas de peixes que receberam dietas contendo alta energia, somente aumentando o consumo de alimento. A quantidade de gordura corporal aumentou com o aumento dos teores de gordura na dieta, enquanto uma relação inversa ocorreu em relação à proteína corporal. Os autores observaram ainda um aumento do volume do trato gastrointestinal dos peixes que receberam dietas com altos níveis de gordura em função da expansão dos cecos pilóricos e do intestino, resultado de uma lenta passagem do alimento pelo trato gastrointestinal.

A exigência protéica de uma espécie e o teor de proteína de uma ração é influenciada por fatores como tamanho do peixe, função fisiológica, qualidade da proteína e fatores econômicos. Entretanto, a taxa de crescimento pode aumentar mais rapidamente devido a uma melhora na conversão alimentar, associada a um aumento da quantidade de alimento ingerido por refeição (NRC, 1993). Por exemplo, Page \& Andrews (1973) demonstraram que para o bagre do canal, 25\% de proteína na ração é adequado para peixes de 114 - $500 \mathrm{~g}$, mas um teor de $35 \%$ de proteína induz crescimento mais rápido do que $25 \%$ de proteína para peixes com 14 a $100 \mathrm{~g}$.

Segundo Podoskina et al. (1997), a digestibilidade da proteína para truta arcoíris não variou entre as dietas que continham $20 \%$ de amido de batata em diferentes formas. Este autor relata que a substituição do amido de batata cru por amido gelatinizado a $70^{\circ} \mathrm{C}$, não causa mudança na RHS. A RHS foi maior $(1,47 \%)$, para os peixes alimentados com dextrina. Bergot \& Breque (1983) relataram que a digestibilidade da proteína para a truta arco-íris não foi afetada pelas fontes de amido cru ou cozido - comparadas em iguais níveis de alimentação.

Em função da pequena quantidade de material biológico disponível, os dados de glicogênio muscular e no fígado e RHS foram submetidos apenas a uma análise gráfica de tendência, como segue (Figuras 10 a 12). 


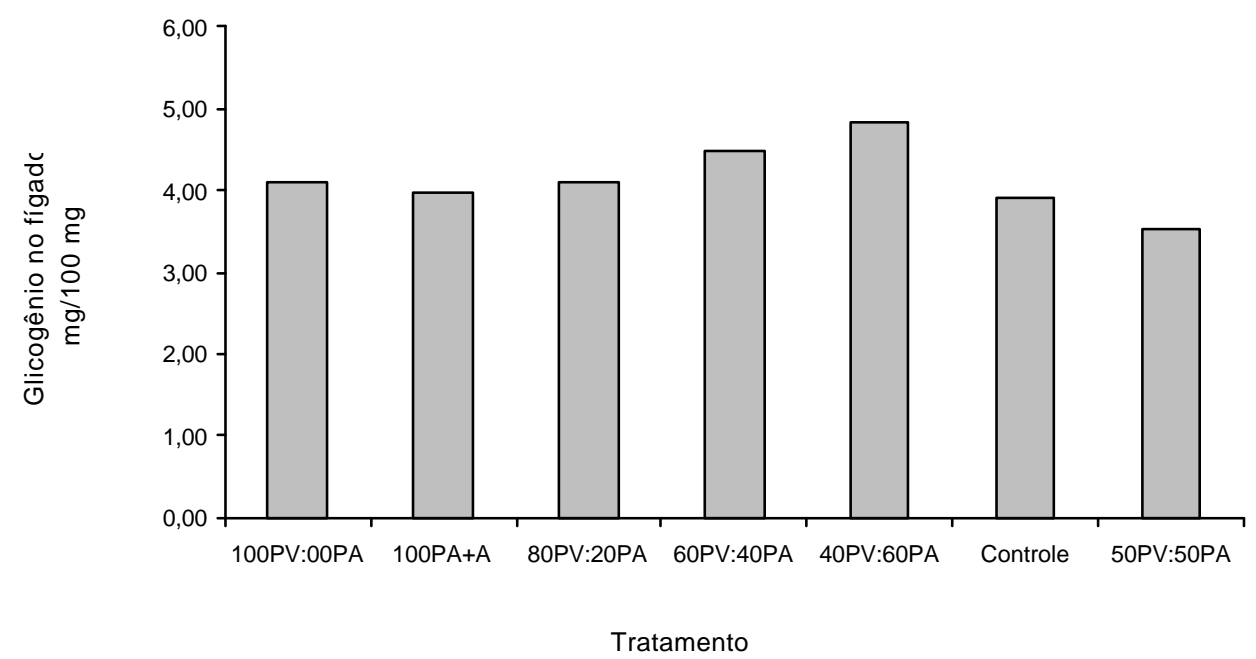

Figura 10 - Concentrações de glicogênio no fígado de juvenis de black bass alimentados com dietas contendo diferentes proporções de proteína animal e vegetal

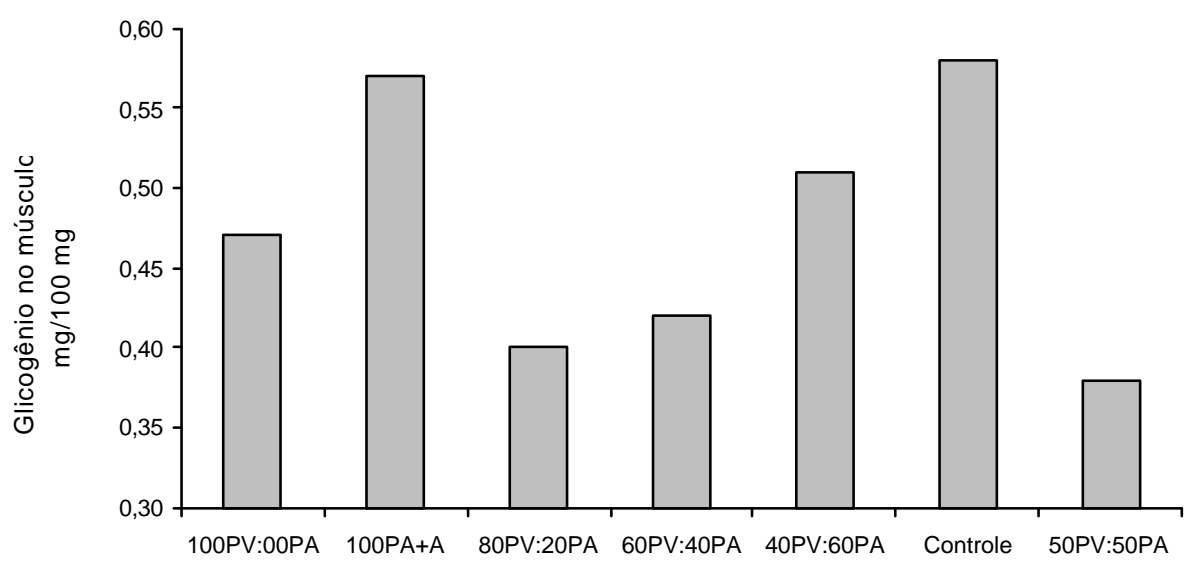

Tratamento

Figura 11 - Concentrações de glicogênio no músculo de juvenis de black bass alimentados com dietas contendo diferentes proporções de proteína animal e vegetal 


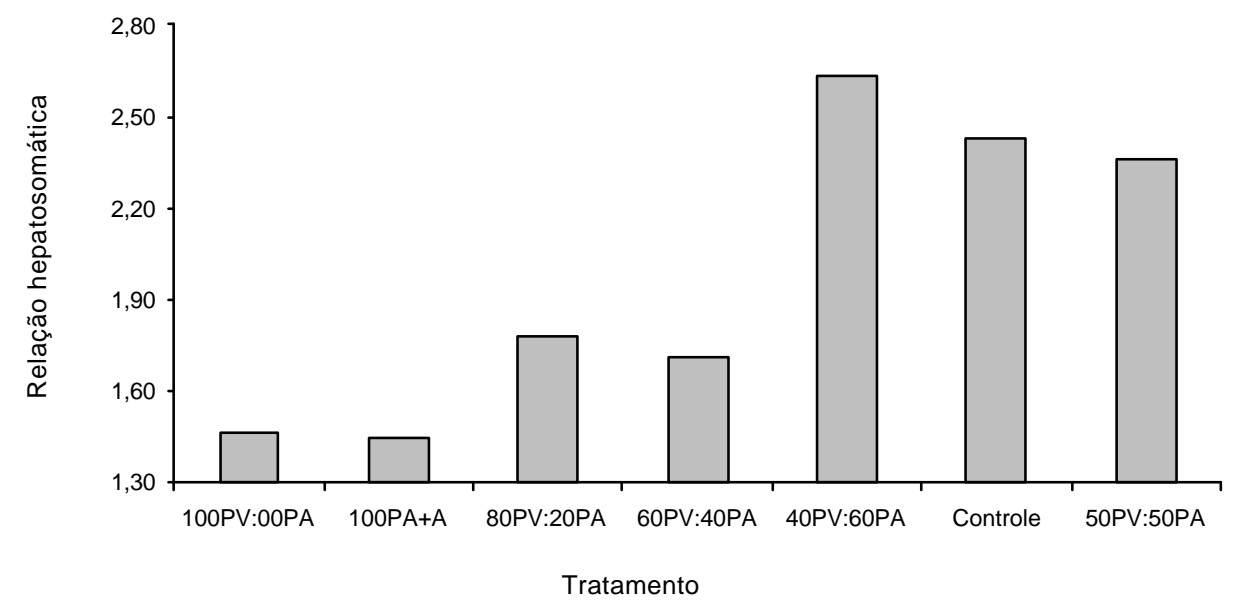

Figura 12 - Relação hepatosomática de juvenis de black bass alimentados com dietas contendo diferentes proporções de proteína animal e vegetal

Robaina et al. (1995) observaram aumento da deposição de lipídio no fígado associado à diminuição de glicogênio em peixes alimentados com farelo de soja. Estes resultados são similares àqueles obtidos no presente experimento (Tabela 9). Os teores de extrato etéreo no fígado dos peixes dos tratamentos que receberam as maiores proporções de proteína de origem vegetal são maiores (100PV:0PA, 100PV+PA, 80PV:20PA e 60PV:40PA) do que os demais. O tratamento controle era representado por dieta contendo alto teor de farelo de soja (34,97\%), mas apresentava também em sua composição, farinha de peixe e farinha de vísceras, ingredientes considerados de boa digestibilidade e palatabilidade (Portz, 1999). Segundo Steffens (1989), o glicogênio está presente no fígado em quantidades proporcionalmente maiores do que no músculo, $0,15 \%$ versus $2,5 \%$ do peso vivo, respectivamente, mas em termos absolutos, a quantidade de glicogênio contida no músculo é maior.

A ausência de carboidrato pode induzir a liberação de uma importante fração dos aminoácidos a partir da digestão da proteína muscular e da ração, para serem utilizados para gluconeogênese e não na síntese de proteína e crescimento. Segundo 
Wilson (1994), é necessário fornecer uma quantidade apropriada deste nutriente (aproximadamente 20\%) para assegurar máxima utilização de outros nutrientes.

A inclusão de $20 \%$ de carboidrato na dieta apresentou melhor resultado para juvenis de "sunshine bass", comparado a 40\% de inclusão (Hutchins et al.,1998), aproximando-se dos dados de formulação do presente trabalho - $18 \%$ de inclusão de amido. Carboidratos solúveis aumentam a deposição de gordura na cavidade abdominal e no músculo, mas não no fígado. Os carboidratos absorvidos que não são utilizados como energia podem acumular no fígado como energia ou glicogênio após serem convertidos.

"Sunshine bass" alimentados com dietas contendo carboidratos apresentaram fígado maiores, com mais glicogênio e menos lipídio, matéria seca e proteína, quando comparados a peixes alimentados com dietas sem carboidrato. Segundo Wilson (1994), em geral o tamanho do fígado e o conteúdo de glicogênio aumentam com o aumento dos níveis de carboidrato dietético em muitas espécies de peixes. Os tratamentos 100PV:0PA, 100PV+PA, 80PV:20PA e 60PV:40PA, apresentaram menor RHS que os demais, ou seja, menor acúmulo de nutrientes devido a menor digestibilidade dos ingredientes de origem vegetal (Figura 12).

Estas observações corroboram as recomendações de Watanabe et al. (1997), que a utilização de uma combinação de diferentes fontes de proteína é uma alternativa melhor que a inclusão de altos níveis de uma única fonte de proteína de origem vegetal em uma dieta. Esta prática pode exacerbar problemas, não só relacionados ao balanço de aminoácidos essenciais, mas também relacionados aos possíveis efeitos dos fatores antinutricionais.

O glicogênio hepático é considerado um estoque emergencial de energia, prontamente utilizável nos primeiros momentos de situações críticas de estresse (Christiansen \& Klungsoyr, 1987). O catabolismo do glicogênio hepático mostra que esta forma de reserva orgânica é muito mais importante como suprimento de intermediários metabólicos para processos biossintéticos, que como fonte de energia (Christiansen \& Klungsoyr, 1987). O glicogênio é um nutriente muito utilizado em adaptações bioquímicas em situação de estresse ambiental. Variações de pH, dos níveis 
de oxigênio dissolvido na água, da salinidade, e períodos de grande esforço físico e mudanças de dietas podem resultar tanto em aumento como em diminuição do estoque de glicogênio tecidual (Moraes et al., 1996; Soengas et al., 1995).

Muitos estudos, conduzidos com diferentes espécies de peixes, nas mais diversas condições ambientais, têm utilizado a avaliação da RHS e do peso da grdura visceral como forma de quantificar o estoque energético em peixes (Bidinoto et al., 1997). Brown et al. (1992), observaram ainda que os valores da RHS encontrados para juvenis de "sunshine bass" eram inversamente proporcionais aos níveis de proteína e diretamente proporcionais aos níveis de carboidratos digestíveis dietéticos, o que mostra que quanto menor o nível de proteína dietética, maior a utilização de carboidratos e a deposição de glicogênio no tecido hepático. Resultados semelhantes também foram mostrados por Millikin (1982) para o "stripped bass". O mesmo não foi observado no presente experimento com o black bass.

A relação entre a quantidade de gordura visceral e o peso do corpo apresenta um declínio diretamente proporcional ao aumento da quantidade de proteína dietética, de forma similar a RHS (Brown et al., 1992). Os resultados obtidos no Experimento 3, mostraram que os maiores valores para proteína disponível foram relacionados aos tratamentos 100PV:0PA $(39,01 \%), 100 \mathrm{PV}+\mathrm{A}(41,73 \%)$ e que por sua vez, apresentaram os menores valores de RHS. Da mesma forma, os tratamentos 40PV:60PA (33,35\%), controle $(26,08 \%)$ e 50PV:50PA (33,82\%), apresentarm valores comparativamente menores para proteína disponível e conseqüentemente, maior RHS. Os tratamentos 80PV:20PA e 60PV:40PA não mostraram a mesma tendência. As reservas energéticas dos peixes são geralmente representadas por um acúmulo de gordura visceral. Tais reservas em peixes não sexualmente maduros podem acontecer como acúmulo de gordura muscular, e são necessárias para crescimento e como reserva energética para o período de falta de alimento ou anorexia de inverno (Wicker \& Johnson, 1987).

Goodwin et al. (2002) observaram alta mortandade de black bass como resultado do acúmulo de glicogênio no fígado. Amostras histológicas do fígado revelaram altas quantidades de glicogênio, necrose dos hepatócitos, inflamação e regeneração nodular. A maior incidência de casualidades ocorreu durante o inverno. Em 
adição, este problema também foi relacionado por produtores ao uso de dietas contendo altos níveis de carboidratos disponíveis.

A formulação das dietas extrusadas e pelletizadas, com 19 e $17 \%$ de carboidratos, respectivamente, utilizadas por dois produtores eram praticamente idênticas, mas somente os peixes que utilizaram a dieta extrusada sofreram danos ao fígado. $\mathrm{O}$ processo de extrusão aumenta substancialmente a digestibilidade de carboidratos complexos. Consequientemente, os peixes alimentados com a dieta extrusada consumiram mais carboidratos do que os peixes alimentados com a dieta peletizada. Neste estudo, a RHS variou de 1,9 a 2,6 e foi menor nos peixes alimentados com a dieta contendo $45 \%$ de proteína e $25 \%$ de lipídio. A proteína corporal variou de 12,3 a 14,9\% e a proteína hepática variou de 12,5 a 14,2\%. Em resumo, uma redução na quantidade de carboidrato disponível de 27 para $20 \%$ melhora as condições do fígado e a resistência ao transporte; diminui o estresse e a taxa de mortandade de uma população de peixes carnívoros.

Vários autores comentam que o farelo de soja é palatável e apresenta um perfil de aminoácidos favorável, além de ser utilizado por várias espécies com relativo sucesso. Porém, deve-se limitar as quantidades utilizadas, devido a problemas de palatabilidade e principalmente quanto à necessidade de suplementação com aminoácidos sintéticos. Alevinos de "red drum" (0,4 g) apresentaram decréscimo no ganho de peso quando a quantidade de farinha de peixe diminuiu de 60 para $45 \%$ da dieta, substituída por quantidade equivalente da proteína pelo farelo de soja (Davis et al., 1995). Os autores acreditam que o crescimento desta espécie foi prejudicado por uma deficiência de aminoácidos sulfurosos, pois a adição de metionina à dieta aumentou a taxa de crescimento. Davis et al. (1995) também sugerem que a adição de atrativos as rações contendo altos níveis de farelo de soja pode aumentar o ganho de peso de espécies carnívoras. Um exemplo limite é dado por Refstie et al. (1997), que relataram que a truta arco-íris se adaptou a dietas contendo $67 \%$ da proteína oriunda do farelo de soja.

Os valores médios da composição das fezes e dos coeficientes de digestibilidade das rações para os juvenis de black bass estão apresentados na Tabela 10. 
Independentemente dos tratamentos, as fezes coletadas apresentaram forma sólida e consistente. Não houve mortalidade de peixes alimentados com as diferentes rações durante o período de coleta de fezes e nem casos de recusa dos diferentes tipos de rações fornecidas.

Tabela 10. Composição nutricional das fezes e coeficientes de digestibilidade dos nutrientes de juvenis de black bass alimentados com dietas contendo diferentes proporções de proteína animal e vegetal

\begin{tabular}{lccccccc}
\hline Composição em & \multicolumn{7}{c}{ Dieta } \\
\cline { 2 - 7 } nutrientes & $100 \mathrm{PV}: 0 \mathrm{PA}$ & $100 \mathrm{PV}+\mathrm{A}$ & $80 \mathrm{PV}: 20 \mathrm{PA}$ & $60 \mathrm{PV}: 40 \mathrm{PA}$ & $40 \mathrm{PV}: 60 \mathrm{PA}$ & Controle & $50 \mathrm{PV}: 50 \mathrm{PA}$ \\
\hline Proteína, \% & 11,29 & 10,38 & 11,11 & 9,70 & 16,38 & 13,22 & 16,49 \\
Extrato etéreo, \% & 3,32 & 3,37 & 3,10 & 2,77 & 1,58 & 3,80 & 2,46 \\
Fibra bruta, \% & 9,34 & 10,02 & 8,00 & 8,61 & 6,48 & 9,27 & 7,00 \\
Cálcio, \% & 2,71 & 1,92 & 2,16 & 1,59 & 6,68 & 2,07 & 7,16 \\
Fósforo, \% & 2,07 & 1,20 & 1,24 & 0,72 & 3,33 & 0,65 & 3,11 \\
Matéria mineral, \% & 12,37 & 8,56 & 9,06 & 8,07 & 24,19 & 7,51 & 21,60 \\
E.B.(kcal/kg) & $3.889,75$ & $4.198,25$ & $4.158,50$ & $3.993,75$ & $3.314,50$ & $4.204,75$ & $3.868,25$ \\
Óxido de cromio, \% & 1,31 & 1,24 & 1,14 & 1,06 & 0,96 & 1,03 & 1,03 \\
Digestibilidade (CDA) & & & & & & \\
Matéria seca, \% & $61,91^{\mathrm{a}}$ & $73,94^{\mathrm{a}}$ & $57,19^{\mathrm{a}}$ & $55,34^{\mathrm{ab}}$ & $50,47^{\mathrm{ab}}$ & $50,48^{\mathrm{ab}}$ & $49,63^{\mathrm{ab}}$ \\
Proteína, \% & $90,15^{\mathrm{a}}$ & $93,89^{\mathrm{a}}$ & $89,25^{\mathrm{ab}}$ & $89,92^{\mathrm{a}}$ & $80,49^{\mathrm{b}}$ & $84,70^{\mathrm{b}}$ & $80,36^{\mathrm{b}}$ \\
Disponível, \% & $39,01^{\mathrm{b}}$ & $41,73^{\mathrm{a}}$ & $28,76^{\mathrm{b}}$ & $29,16^{\mathrm{b}}$ & $33,35^{\mathrm{bc}}$ & $26,08^{\mathrm{bc}}$ & $33,82^{\mathrm{bc}}$ \\
Energia, \% & $67,94^{\mathrm{a}}$ & $77,05^{\mathrm{a}}$ & $61,56^{\mathrm{a}}$ & $64,85^{\mathrm{a}}$ & $65,93^{\mathrm{a}}$ & $58,57^{\mathrm{ab}}$ & $54,95^{\mathrm{ab}}$ \\
Disponível, kcal/kg & $3.140,29^{\mathrm{a}}$ & $3.671,46^{\mathrm{a}}$ & $2.141,98^{\mathrm{ab}}$ & $2.444,99^{\mathrm{a}}$ & $2.923,23^{\mathrm{ab}}$ & $2.162,26^{\mathrm{ab}}$ & $2.391,50^{\mathrm{b}}$ \\
ED:PD & $8,05^{\mathrm{a}}$ & $8,80^{\mathrm{a}}$ & $7,42^{\mathrm{a}}$ & $8,38^{\mathrm{a}}$ & $8,76^{\mathrm{a}}$ & $8,29^{\mathrm{a}}$ & $7,05^{\mathrm{ab}}$ \\
ED:PB & $7,26^{\mathrm{a}}$ & $8,26^{\mathrm{a}}$ & $6,65^{\mathrm{a}}$ & $7,54^{\mathrm{a}}$ & $7,05^{\mathrm{a}}$ & $7,02^{\mathrm{a}}$ & $5,68^{\mathrm{ab}}$ \\
Extrato etéreo, \% & $84,00^{\mathrm{a}}$ & $89,01^{\mathrm{a}}$ & $84,99^{\mathrm{a}}$ & $85,82^{\mathrm{a}}$ & $88,88^{\mathrm{a}}$ & $83,74^{\mathrm{a}}$ & $81,97^{\mathrm{a}}$ \\
Matéria mineral, \% & $15,59^{\mathrm{c}}$ & $59,98^{\mathrm{b}}$ & $45,74^{\mathrm{b}}$ & $73,37^{\mathrm{ab}}$ & $13,27^{\mathrm{c}}$ & $46,03^{\mathrm{b}}$ & $16,40^{\mathrm{c}}$ \\
Fósforo, \% & $12,44^{\mathrm{c}}$ & $70,71^{\mathrm{a}}$ & $50,73^{\mathrm{b}}$ & $86,19^{\mathrm{a}}$ & $29,38^{\mathrm{c}}$ & $64,82^{\mathrm{ab}}$ & $28,55^{\mathrm{bc}}$ \\
\hline
\end{tabular}


$\mathrm{O}$ tratamento $100 \mathrm{PV}+\mathrm{A}$ apresentou os valores mais altos $(73,94 \%)$ para o coeficiente de digestibilidade da matéria seca $\left(\mathrm{CDA}_{\mathrm{MS}}\right)$, diferenciando $(\mathrm{P}<0,05)$ dos tratamentos 60PV:40PA (55,34\%), 40PV:60PA (50,47\%), controle (50,48\%) e 50PV:50PA (49,63\%). Em relação ao coeficiente de digestibilidade da proteína bruta $\left(\mathrm{CDA}_{\mathrm{PB}}\right)$, o melhor valor também foi para o tratamento 100PV+A $(93,89 \%)$ que entretanto, não apresentou diferença para os tratamentos 100PV:0PA (90,15\%), 80PV:20PA (89,25\%) e 60PV:40PA (89,92\%). Os tratamentos 40PV:60PA (80,49\%), controle $(84,70 \%)$ e 50PV:50PA (80,36\%) também não diferiram entre si $(\mathrm{P}>0,05)$, mas diferiram do primeiro grupo $(\mathrm{P}<0,05)$. Os coeficientes de digestibilidade da energia bruta $\left(\mathrm{CDA}_{\mathrm{EB}}\right)$ e extrato etéreo $\left(\mathrm{CDA}_{\mathrm{EE}}\right)$ também apresentaram a mesma tendência dos $\mathrm{CDA}_{\mathrm{MS}}$ e $\mathrm{CDA}_{\mathrm{PB}}$, ou seja, o tratamento 100PV+A apresentou os melhores resultados, respectivamente $77,05 \%$ e $89,01 \%$. Porém não foram observadas diferenças entre os tratamentos $(\mathrm{P}>0,05)$. Apenas os tratamentos controle $(58,57 \%)$ e 50PV:50PA $(54,95 \%)$ foram diferentes dos demais $(\mathrm{P}<0,05)$ para о $\mathrm{CDA}_{\mathrm{EB}}$. Os melhores valores para os coeficientes de digestibilidade da matéria mineral (CDAMM) e do fósforo (CDAp) foram para o tratamento 60PV:40PA $(73,37 \%$ e $86,19 \%$, respectivamente) que entretanto, não apresentaram diferença $(\mathrm{P}>0,05)$ para os tratamentos 100PV+A, 80PV:20PA e controle.

Os peixes utilizam em torno de $80 \%$ da matéria seca da ração. Como o cromio não é absorvido, é teoricamente eliminado nas fezes. Por esta razão a concentração de cromio nas fezes é sempre maior, a exemplo dos resultados obtidos no presente experimento. A confiabilidade dos resultados dos CDA é definida pelo sistema ou método de coleta das fezes utilizados nos experimentos de digestibilidade com peixes. As fezes podem ser coletadas por diferentes métodos como a dissecação, compressão ou sucção anal (Small et al., 1999; Storebakken et al., 2000; Sullivan \& Reigh, 1995); filtração ou coleta contínua automática (Burel et al., 2000; Choubert et al., 1979); pipetagem das fezes no aquário (Spyridakis et al., 1989), ou por câmaras metabólicas (Smith et al., 1980). Todos estes métodos têm sido amplamente revisados por diversos pesquisadores (Cho, 1982; De Silva \& Anderson, 1995; Steffens, 1989; Watanabe, 1988) e o uso de cada um apresenta vantagens e desvantagens específicas. 
As proteínas não são idênticas em seus valores nutricionais. $\mathrm{O}$ valor nutricional de uma fonte de proteína é função da digestibilidade e da composição em aminoácidos. Existem alguns ingredientes protéicos que contêm altos níveis de proteína bruta, mas que contêm uma grande proporção de nitrogênio não-protéico. Neste caso, estes ingredientes não contribuem com aminoácidos suficientes para suprir as exigências nutricionais das espécies e simplesmente aumentam a produção de amônia e excreção de nitrogênio pelos peixes, com prejuízos à produtividade e à qualidade da água do sistema de criação (Cho, 1990).

Segundo Morales et al. (1999) é necessário minimizar as perdas de nutrientes por lixiviação na água quando se utiliza métodos de coleta com o peixe dentro da água, a fim de evitar super estimativas dos valores de CDAs dos nutrientes. O mesmo é verdade em relação ao marcador utilizado. A opção pelo uso do óxido de cromio neste estudo, deve-se ao fato do mesmo ser amplamente utilizado em experimentos de digestibilidade em função da simplicidade de aplicação e precisão na metodologia de análise (De Silva et al., 1997).

Sugiura et al. (1998) não dsservaram diferença significativa entre os CDAs para proteína bruta das farinhas de arenque $(94,6 \%)$, de menhaden $(89,8 \%)$ e de vísceras de frango $(95,9 \%)$ para truta arco-íris, resultados semelhantes aos encontrados por Portz (2001), trabalhando com o black bass. Ellis \& Smith (1984) relatam que o CDA do lipídio da farinha de arenque foi 89,8\%. Portz (2001) não encontrou diferença no CDA do lipídio entre a farinha de peixe $(98,21 \%)$ e a farinha de vísceras $(98,19 \%)$ para o carnívoro black bass. A partir destes relatos e dos resultados deste trabalho, podemos inferir que a utilização da farinha de peixe em rações para peixes carnívoros não é uma necessidade estrita quando a farinha de vísceras faz parte das fontes protéicas escolhidas.

Trabalhos desenvolvidos por Britz \& Hecht (1997), Catacutan \& Coloso (1995), Dias et al. (1998), El Sayed \& Teshima (1992), Garling \& Wilson (1976), Lee \& Putman (1973), Rojas \& Verdegem (1994), Samantaray \& Mohanty (1997) e Tibaldi et al. (1996), utilizando peixes carnívoros como material biológico, determinaram que a melhor relação energia:proteína para alimentação das espécies carnívoras está entre 7 e 9 kcal ED/g de proteína. Sampaio (1998) observou que juvenis de tucunaré (10 g), 
apresentaram ganho de peso de $20 \mathrm{~g}$ em 60 dias, com índices de conversão alimentar de $1,2: 1$, consumindo uma dieta seca contendo $41 \%$ de proteína bruta, $3.500 \mathrm{kcal} / \mathrm{kg}$ de ração, uma relação ED:PB de $8 \mathrm{kcal} / \mathrm{g}$ de proteína. Considerando que a exigência em proteína diminui com o aumento do tamanho do peixe, o autor inferiu que peixes maiores podem consumir rações com 36 a 37\% de PB e 9 kcal/g de proteína, sem redução no ganho de peso e qualidade da carne do produto final, o que resulta em grande redução no preço das rações.

Trabalhando com juvenis de black bass com peso médio inicial de $14 \mathrm{~g}$, Portz et al. (2001) e Cyrino et al. (2000), demonstraram que a espécie apresenta exigências nutricionais mínimas de 43,59\% de PB e $3.871 \mathrm{kcal}$ de ED/kg de alimento e limites da relação ED:PB entre 7,78 e 8,83 kcal/g. Nestas condições, o black bass apresenta alto percentual de glicogênio hepático e aumento da RHS, mostrando uma alta capacidade de armazenamento da energia, tanto prontamente utilizável - glicogênio - como de reserva orgânica - lipídios. Apesar de ser um carnívoro por excelência, o black bass pode aproveitar bem rações contendo níveis de carboidratos entre 24-30\%. Para tanto, a quantidade de lipídios na dieta deve permanecer entre 10 e 12\%, a fim de que a relação energia:proteína não exceda um limite de 8,0 kcal ED/g. Níveis superiores a estes induzem grandes acúmulos de gordura visceral e podem trazer problemas quanto à qualidade da carcaça.

A maioria dos ingredientes protéicos é altamente digerível pelos peixes. Os coeficientes de digestibilidade de ingredientes protéicos variam entre 75 e $95 \%$ e normalmente os valores menores estão associados a concentrações maiores de carboidratos (Rychly \& Spannhof, 1979). O superaquecimento durante o processamento da farinha de peixe, pode diminuir consideravelmente o valor nutritivo. Da mesma forma, um aquecimento insuficiente do farelo de soja diminui a disponibilidade da proteína (NRC, 1993). Smith (1976) mostrou que aumentando a temperatura de aquecimento de $127^{\circ} \mathrm{C}$ para $204^{\circ} \mathrm{C}$, aumentou a digestibilidade da proteína do farelo de soja de 45 para $75 \%$.

Avaliando a digestibilidade de rações comerciais para salmões, Hillestad et al. (1999) relataram que os coeficientes de digestibilidade normalmente encontrados na 
Noruega têm sido 87, 90 e $65 \%$ para proteína, gordura e carboidrato, respectivamente (Associação dos Produtores de Ração para Peixes da Noruega). Rações com aproximadamente mesma composição podem apresentar até $10 \%$ de diferença na digestibilidade de energia, em função das diferentes fontes de energia, de proteína, ou de carboidratos utilizadas. Da mesma forma, níveis de carboidratos podem também alterar o valor da digestibilidade. Os lipídios quando administrados isoladamente, ou contidos na dieta, apresentam valores de 85 a 95\%. Os valores de digestibilidade estimados para os lipídios, entretanto, variam freqüentemente quando as concentrações na dieta são baixas (NRC, 1993).

Watanabe \& Pongmaneerat (1993) reportam que em rações extrusadas o farelo de soja em rações pode substituir até $90 \%$ da farinha de peixe em dietas para truta arcoíris sem causar redução no crescimento ou taxa de eficiência protéica. Estes autores também notaram uma piora nos valores de conversão alimentar em dietas contendo altos níveis de farelo de soja, e atribuíram o fato à baixa digestibilidade do amido. Watanabe \& Pongmaneerat (1993) determinaram que a digestibilidade do amido contido no farelo de soja é de aproximadamente 54\%, independentemente do nível de inclusão na dieta.

O amido não cozido apresenta somente $49 \%$ de digestibilidade para a truta arco-íris (NRC, 1993). Entretanto, Wilson \& Poe (1985) observaram que o bagre do canal apresenta digestibilidade acima de $70 \%$ para a energia no amido não cozido. A atividade da amilase em truta arco-íris pode ser afetada pelo tipo e quantidade de carboidrato na dieta, resultando na diminuição da atividade da enzima. Aksnes e Opstvedt (1998) determinaram que a energia digestível do farelo de soja para a truta arco-íris é menor que aquela determinada para a farinha de peixe. Segundo os autores, o conteúdo de carboidrato no farelo de soja é maior e este nutriente apresenta baixa digestibilidade para salmonídeos. A incorporação de ingredientes de origem vegetal às dietas podem afetar o tempo de passagem do alimento pelo trato gastrointestinal, devido à presença de fibras e açúcares, e alterar a digestibilidade dos nutrientes ingeridos pelos peixes (Storebakken et al., 1999).

Allan et al. (2000) avaliaram a digestibilidade de ingredientes alternativos à farinha de peixe em rações para a perca prateada. O coeficiente de digestibilidade 
encontrado foi de $99 \%$ para o trigo, com 12 a $15 \%$ de proteína e $80 \%$ de carboidrato, e a espécie foi considerada relativamente eficiente em digerir e utilizar carboidratos, o que pode explicar a ausência de relação entre o conteúdo de carboidrato e a digestibilidade do nitrogênio que, especialmente em ingredientes de origem animal sujeitos a superaquecimento, pode ser bastante diminuída em função da degradação da lisina e conseqüente diminuição da qualidade da proteína.

Falge et al. (1978) relataram que altos níveis de carboidratos reduzem a atividade da enzima proteolítica e Hepher (1985) já sugeria que a digestibilidade da proteína estaria negativamente relacionada com o conteúdo de carboidrato na dieta. McGoogan \& Reigh (1996) relatam que a digestibilidade da proteína para o "red drum" foi maior para ingredientes com menos de $2 \%$ de fibra, mas acima deste nível não houve relação entre o conteúdo de fibra e digestibilidade da proteína. De fato, carboidratos não digestíveis passam rapidamente através do tratogastrointestinal carreando algumas proteínas não digeridas e afetando então, a digestibilidade da proteína. Entretanto, Storebakken et al. (1998), relatam que o aumento de carboidrato (10-20\%) reduz a digestibilidade da matéria seca, energia e gordura, mas tem pouco efeito na digestibilidade da proteína para truta arco-íris.

A disponibilidade do fósforo pode ser afetada pela forma química do nutriente e pela espécie de peixe. Geralmente, a absorção de fósforo pelos peixes com estômago funcional - e.g. bagre do canal e truta arco-íris - é maior que para peixes sem estômago - e.g. carpa. A biodisponibilidade de fósforo em rações para peixes é uma consideração importante, devido ao efeito do fósforo no ambiente. Portanto, devem ser utilizadas formas de fósforo que apresentem alta disponibilidade em concentrações mínimas para suprir as exigências. Fitato é a principal forma de fósforo em grãos e a disponibilidade para os peixes é relativamente baixa. Por esta razão, a maioria do fósforo presente nos grãos é excretada e pode contribuir para poluição da água (Ketola, 1985).

A inclusão de carboidratos em dietas para o "sea bass" pode levar a um aumento na eficiência da digestibilidade pelo peixe. O efeito economizador da proteína por carboidratos e lipídios foi demonstrado para a espécie, sugerindo a possibilidade de incluir de 12 a $14 \%$ de extrato etéreo e 23,5 a 27,6\% de carboidrato em dietas para o 
"sea bass" contendo 45\% de proteína bruta (Jeong et al., 1991; Pérez et al., 1997). Tal fato pode ser explicado pelo aumento na disponibilidade de alguns ingredientes pelo processo de extrusão (Akimoto et al., 1992; Takeuchi et al., 1990). Desta forma, como também sugerem Brecka et al. (1996) é recomendável que as rações comerciais sejam testadas e avaliadas em ensaios biológicos antes de serem disponibilizadas no mercado. 


\section{CONCLUSÕES}

Apesar de não terem sido observadas diferença entre os tratamentos no Experimento 1, a análise gráfica mostrou que o Fisharom $^{\circledR}$ é um atrativo alimentar eficiente para peixes em níveis de inclusão de até $0,02 \%$. Em relação aos ensaios sobre substituição de fontes protéicas de origem animal por fontes protéicas de origem vegetal nas dietas e digestibilidade de diferentes dietas à base de fontes protéicas de origem animal e fontes protéicas de origem vegetal para o carnívoro black bass, conclui-se que o farelo de soja pode ser utilizado como substituto parcial de fontes protéicas de origem animal em rações formuladas para a espécie e a farinha de vísceras pode ser considerada uma boa opção como fonte protéica de origem animal em rações para peixes carnívoros, uma vez que possui boa digestibilidade, padrão em aminoácidos adequado e alta disponibilidade de fósforo. Pode-se ainda considerar que a necessidade do uso estrito da farinha de peixe em rações para espécies carnívoras é, no mínimo, questionável. A determinação da digestibilidade das rações, visando maior precisão na formulação de rações de custo mínimo para peixes carnívoros, deveria ser constituída em prática de rotina na indústria de alimentação dos organismos aquáticos. A viabilidade financeira do uso ou não de atrativos, associado ao uso de ingredientes de origem vegetal, ainda é questionável, mas isto pode vir a ser uma necessidade em um futuro próximo, especialmente no caso da substituição total da farinha de peixe nas rações em resposta a considerações e restrições ecológicas. 
ANEXOS 


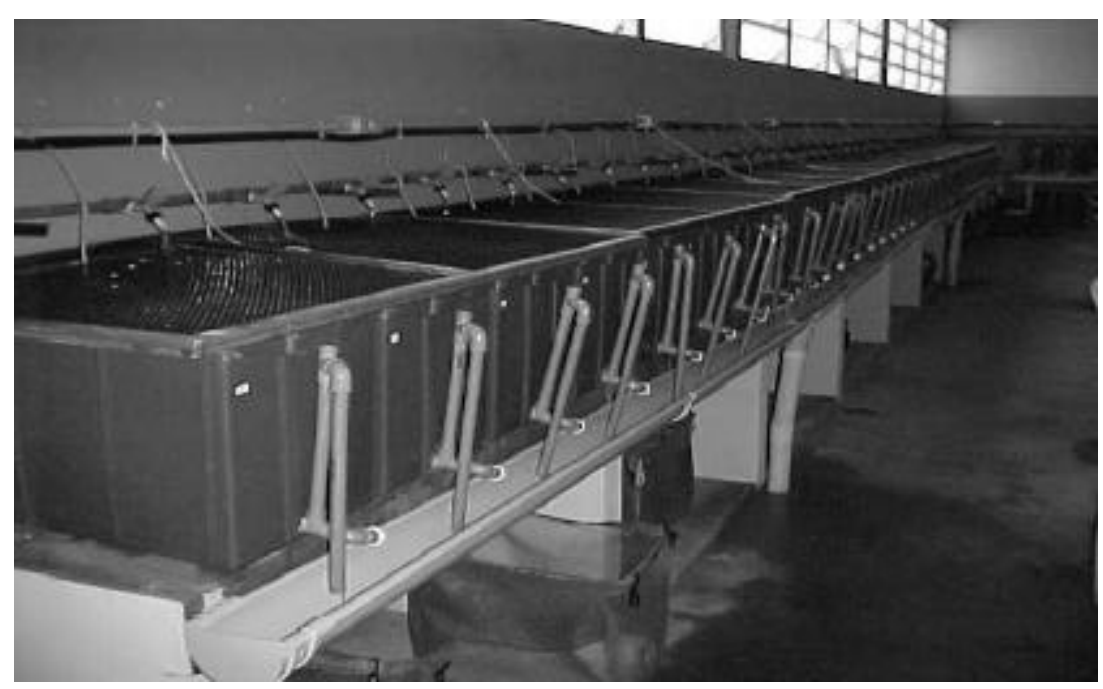

Figura 1 - Disposição dos aquários, onde foi desenvolvido o Experimento 1, no Laboratório de Nutrição de Peixes da ESALQ/USP

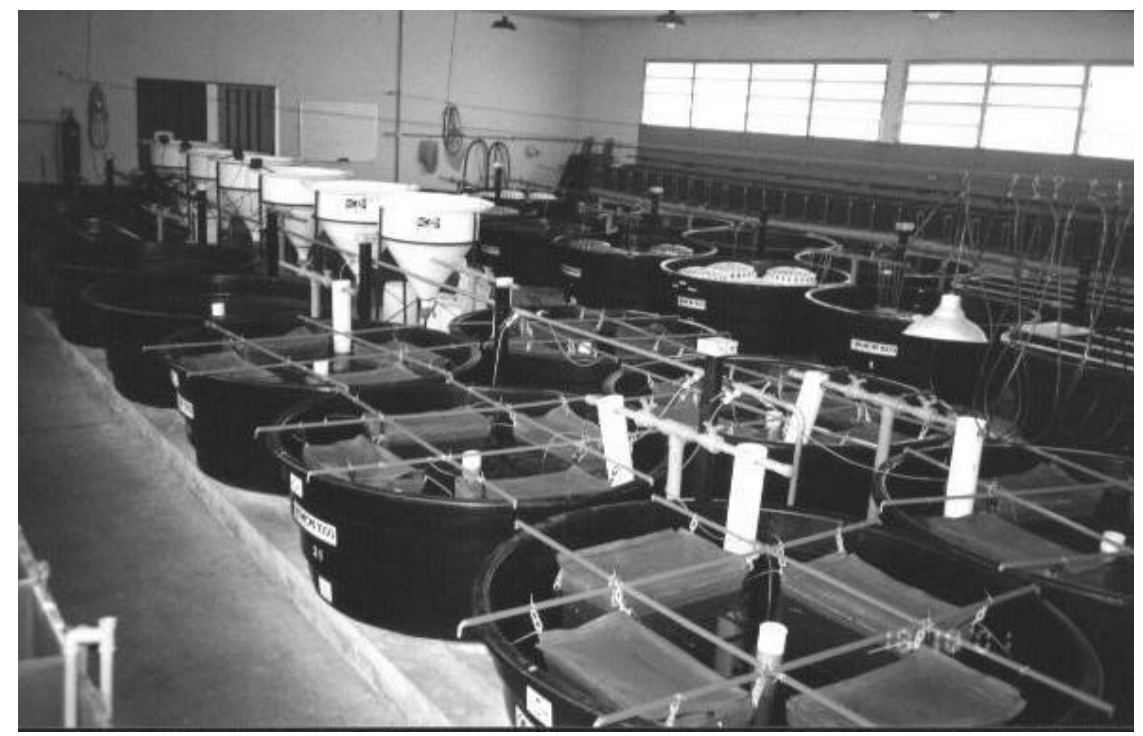

Figura 2 - Disposição das gaiolas, onde foi desenvolvido o Experimento 2, no Laboratório de Nutrição de Peixes da ESALQ/USP 


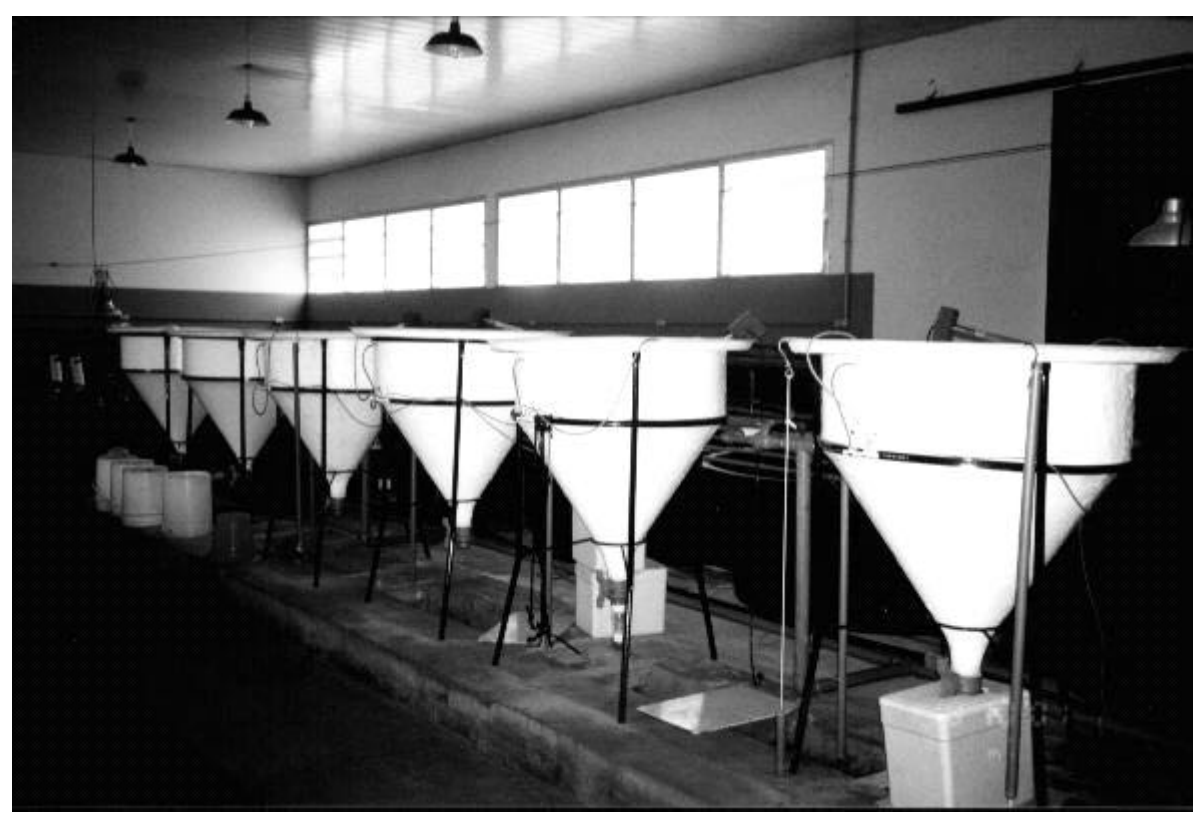

Figura 3 - Disposição dos aquários de digestibilidade onde foi desenvolvido o Experimento 3, no Laboratório de Nutrição de Peixes da ESALQ/USP 


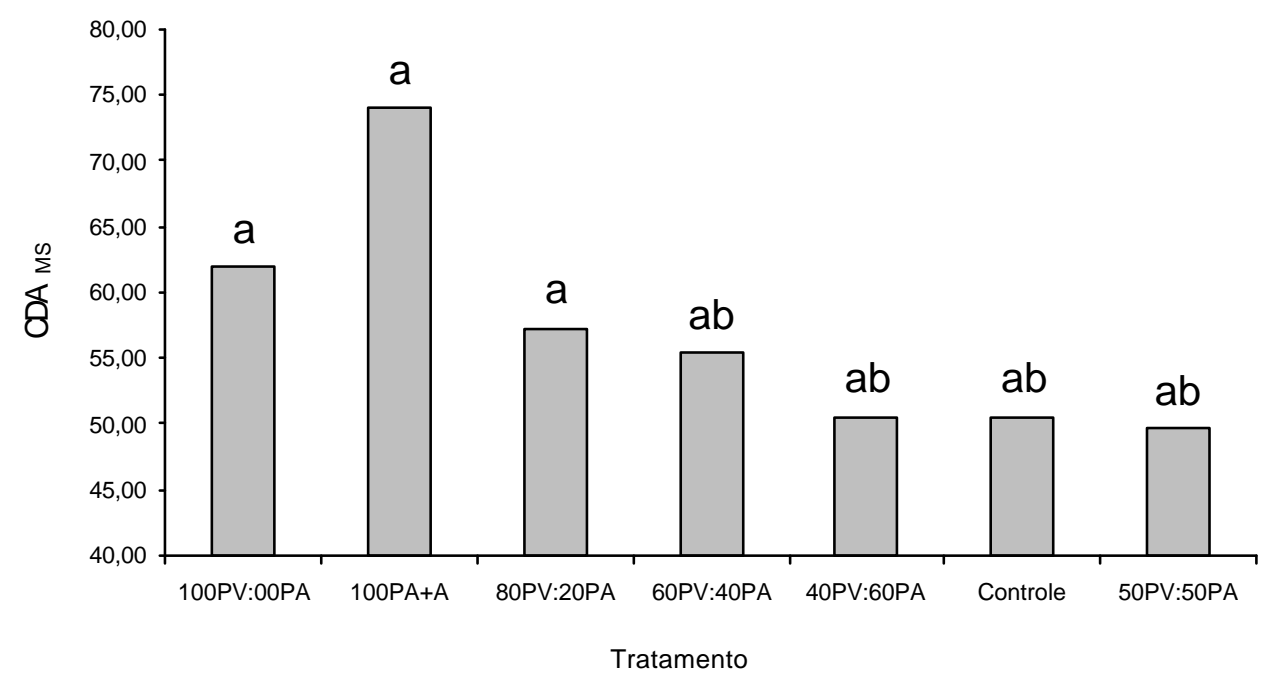

Figura 4 - Coeficiente de digestibilidade da matéria seca para juvenis de black bass alimentados com dietas contendo diferentes proporções de proteína animal e vegetal

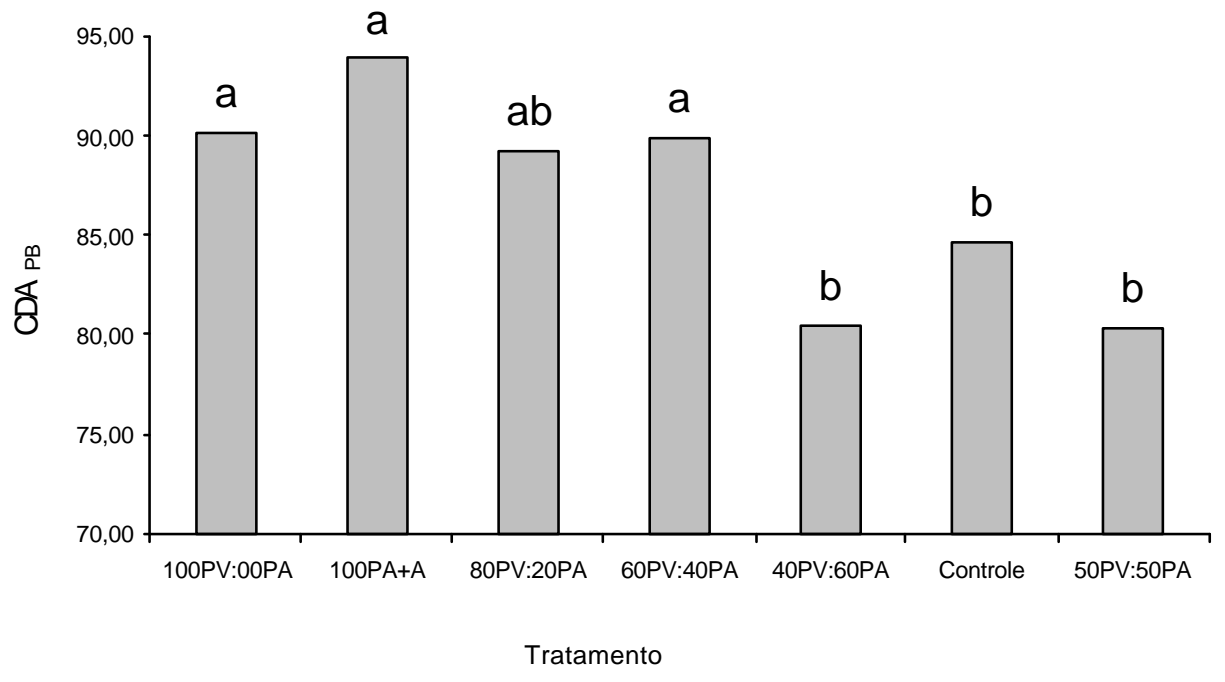

Figura 5 - Coeficiente de digestibilidade da proteína para juvenis de black bass alimentados com dietas contendo diferentes proporções de proteína animal e vegetal 


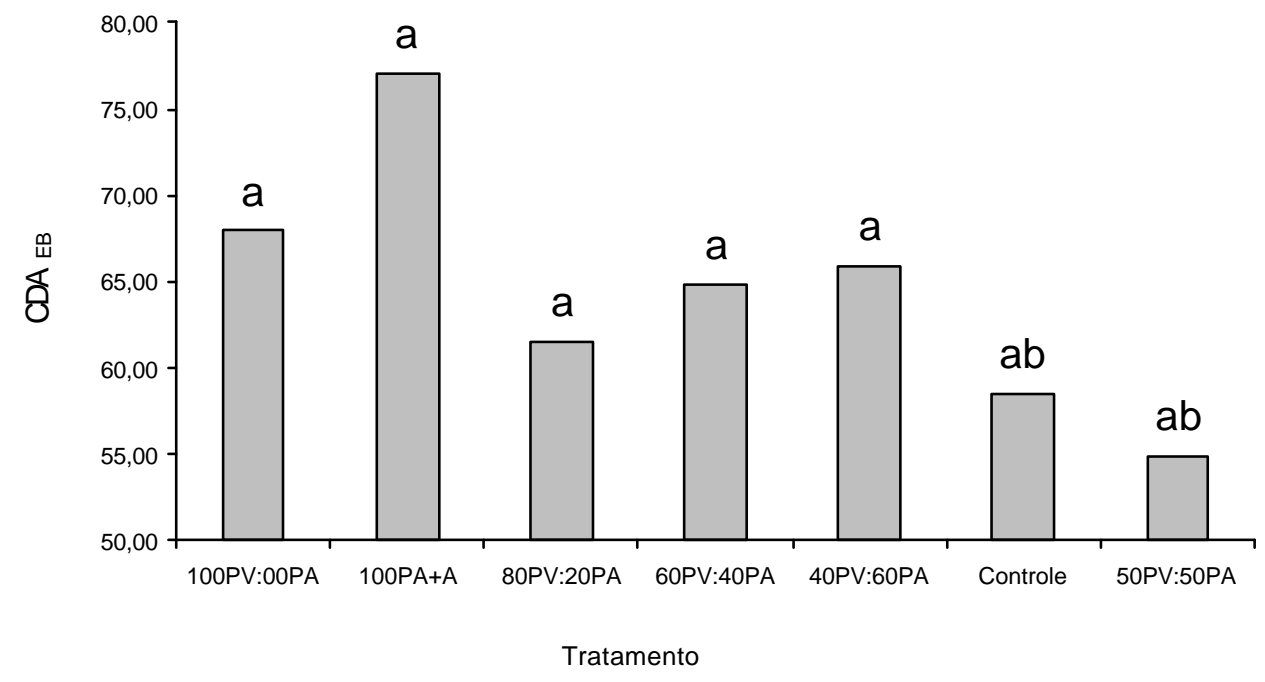

Figura 6 - Coeficiente de digestibilidade da energia para juvenis de black bass alimentados com dietas contendo diferentes proporções de proteína animal e vegetal

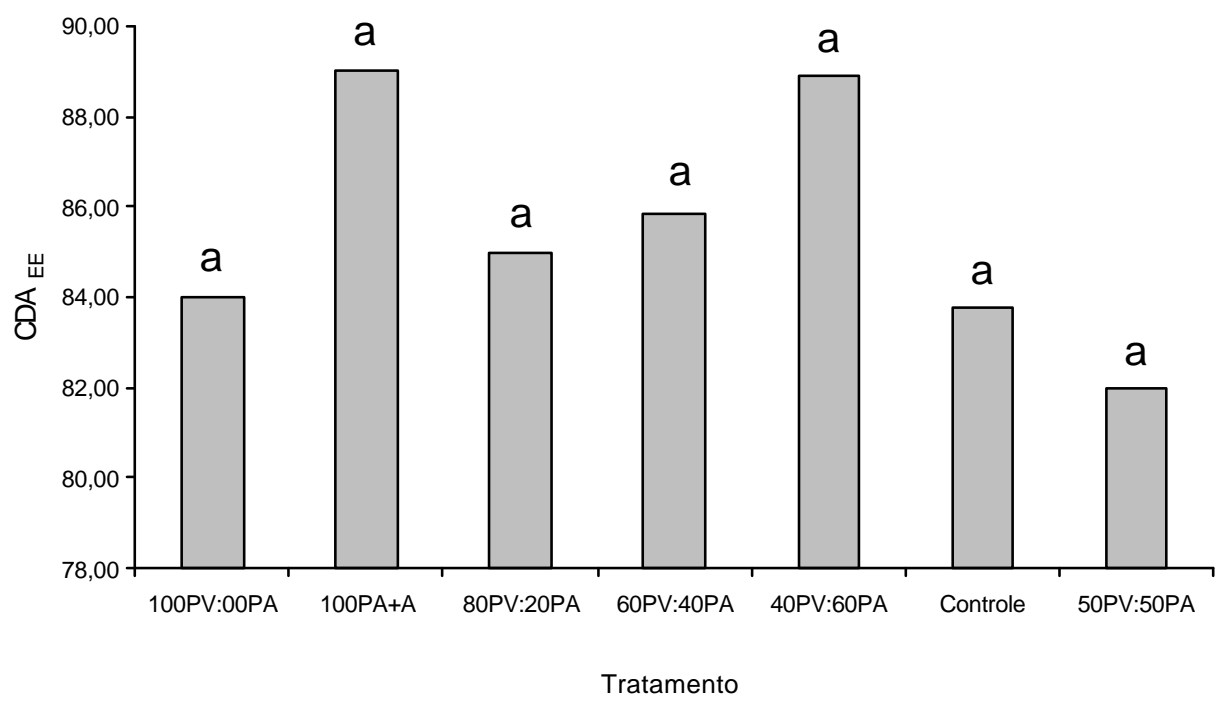

Figura 7 - Coeficiente de digestibilidade do extrato etéreo para juvenis de black bass alimentados com dietas contendo diferentes proporções de proteína animal e vegetal 


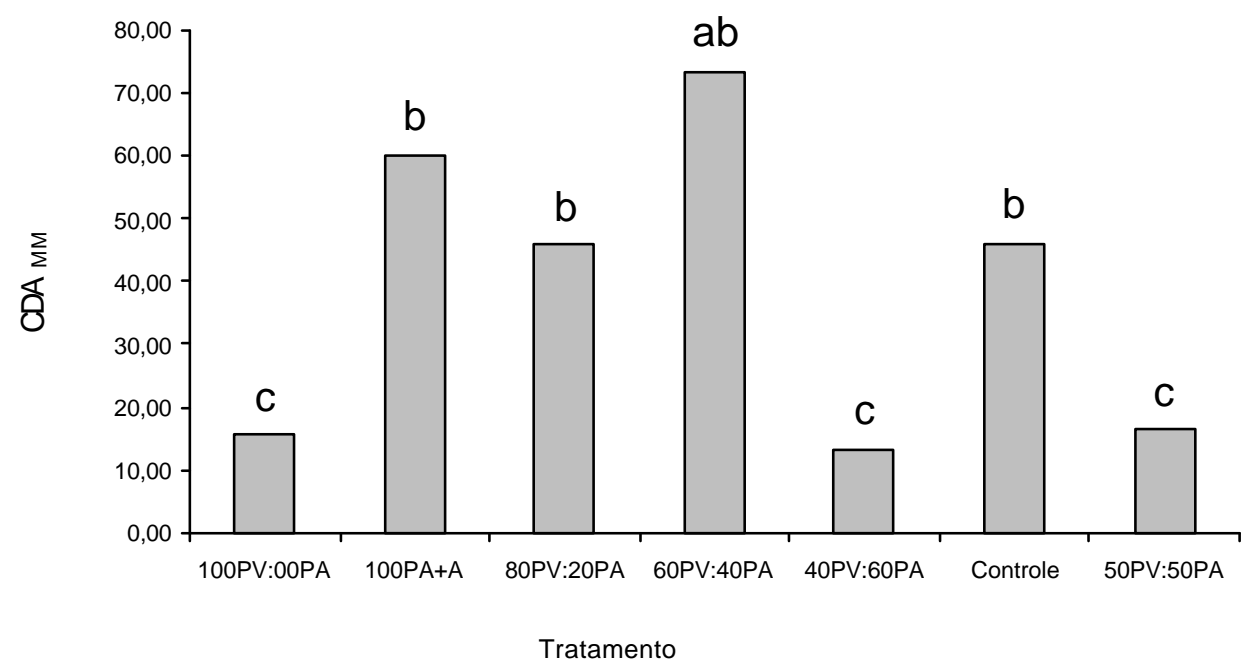

Figura 8 - Coeficiente de digestibilidade da matéria mineral para juvenis de black bass alimentados com dietas contendo diferentes proporções de proteína animal e vegetal

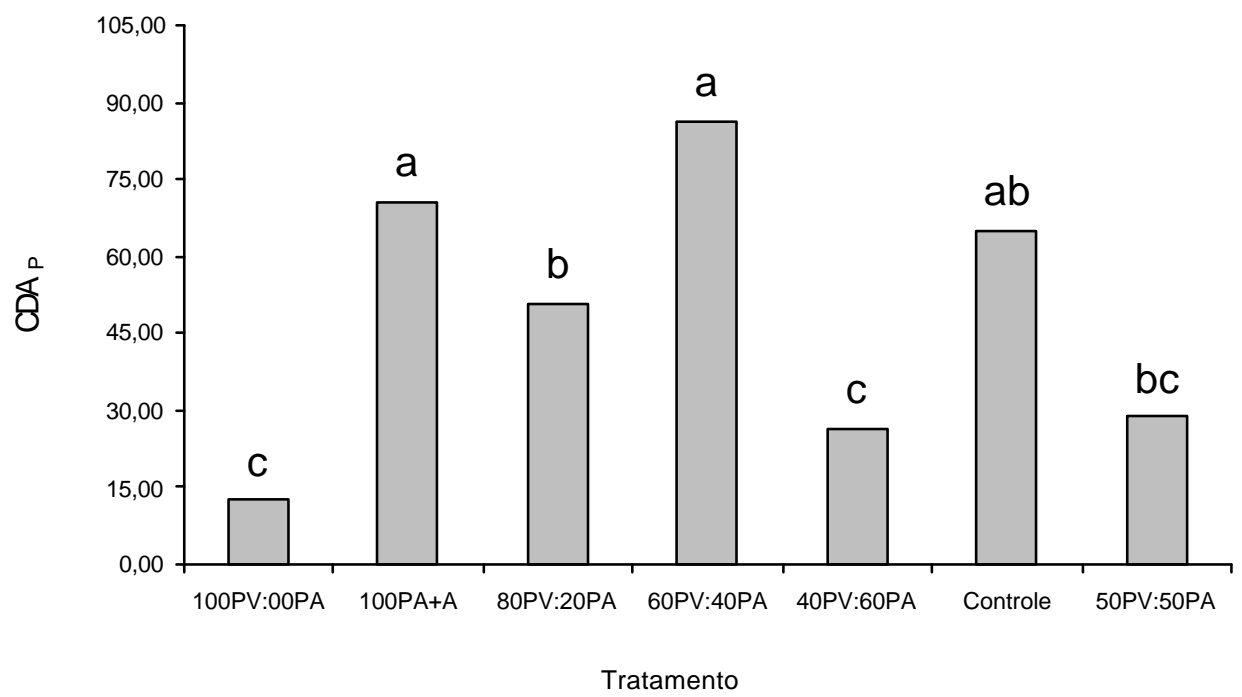

Figura 9 - Coeficiente de digestibilidade do fósforo para juvenis de black bass alimentados com dietas contendo diferentes proporções de proteína animal e vegetal 


\section{REFERÊNCIAS BIBLIOGRÁFICAS}

ADAMS, M.A.; JOHNSEN, P.B.; ZHOU, H-qi. Chemical enhancement of feeding for the herbivorous fish Tilapia zillii. Aquaculture, v.72, p.95-107, 1988.

ADRON, J.W.; BLAR, A.; COWEY, C.B. et al. Effects of dietary energy level and dietary energy source on growth, feed conversion and body composition $\mathrm{f}$ turbot (Scophthalmus maximus L.) Aquaculture, v.111, p.1085-1097, 1976.

AKIMOTO, A.; TAKEUCHI, T.; SATOH, S. et al. Effect of extrusion processing on nutritional value of brown fish meal diets for rainbow trout. Nippon Suisain, v.58, p.1474-1482, 1992.

AKSNES, A.; OPSTVEDT, J. Content of digestible energy in fish feed ingredients determined by the ingredient-substitution method. Aquaculture, v.161, p.45-53, 1998.

AKSNES, A.; IZQUIERDO, M.S.; ROBAINA, L. et.al. Influence of fish meal quality and feed pellet on growth,feed efficiency and muscle composition in gilthead seabream (Sparus aurata). Aquaculture, v.153, p.251-261, 1997.

ALLAN, G.L.; SCOTT, P.; BOOTH, M.A. et al. Replacement of fish meal in diets for Australian silver perch, Bidyanus bidyanus. I. Digestibility of alternative ingredients. Aquaculture, v.186, p.293-310, 2000.

ARRUDA, L.F.; BORGHESI, R.; OETTERER, M. et al. O preparo da silagem de pescado. Panorama da Aquiicultura, v.11, n.65, p.34-36, maio/jun., 2001.

AUSTRENG, E.; STOREBAKKEN, T.; THOMASSEN, M.S. et al. Evaluation of selected trivalent metal oxdes as inert markers used to estimate apparent digestibility in salmonids. Aquaculture, v.188, p.65-78, 2000. 
AZEVEDO, P.; VAZ, J.O.; PARREIRA, W.B. Aclimatação da truta arco-íris em algumas águas de São Paulo. Boletim de Indústria Animal, v.19, p.75-105, 1961.

BERGE, G.M.; STOREBAKKEN, T. Fish protein hydrolyzate in starter diets for Atlantic salmon (Salmo salar) fry. Aquaculture, v.145, p.205-212, 1996.

BERGE, G.M.; GRISDALE-HELLAND, B.; HELLAND, S.J. Soy protein concentrate in diets for Atlantic halibut (Hippoglossus hippoglossus). Aquaculture, v.178, p.139-148, 1999.

BERGOT, F.; BREQUE, J. Digestibility of starch of rainbow trout: effects of the physical state of starch and the intake level. Aquaculture, v.34, p.203-212, 1983.

BIDINOTO, P.M.; MORAES, G.; SOUZA, R.H.S. Hepatic glycogen and glucose in eight tropical fresh water teleost fish: a procedure for field determinations of micro samples. Boletim Técnico do CEPTA, v.10, p.53-60, 1997.

BRECKA, B.J.; WAHL, D.H.; HOOE, M.L. Growth, survival and body composition of largemouth bass fed various commercial diets and protein concentrations. The Progressive Fish Culturist, v.58, p.104-110, 1996.

BRITZ, P.J.; HECHT, T. Effect of dietary protein and energy level on growth and body composition of south African abalone, Haliotis midae. Aquaculture, v.156, p.195210, 1997.

BROMLEY, P.J. Effect of dietary protein, lipid and energy content on the growth of turbot (Scophthalmus maximus L.). Aquaculture, v.19, p.359-369, 1980.

BROWN, M.L.; NEMATIPOUR, G.R.; GATLIN, D.M. Dietary protein requirement of juvenile sunshine bass at different salinities. The Progressive of Fish Culturist, v.54, p.148-156, 1992.

BRUNE, D.E.; TOMASSO, J.R. Aquaculture and water quality. Baton Rouge: The World Aquaculture Society, 1991. 606p.

BUREAU, D.P.; HARRIS, A.M.; BEVAN, D.J. et al. Feather meals and meat and bone meals from different origins as protein sources in rainbow trout (Oncorhynchus mykiss) diets. Aquaculture, 181, p.281-291, 2000. 
BUREL, C.; BOUJARD, T.; TULLI, F. et al. Digestibility of extruded peas, extruded lupin, and rapeseed meal in rainbow trout (Oncorhynchus mykiss) and turbot (Psetta maxima). Aquaculture, v.188, p.285-298, 2000.

BUTOLO, J.E. Qualidade de ingredientes na alimentação animal. Campinas: CBNA, 2002. 430p.

CAHU, C.L.; INFANTE, Z.; QUAZUGUEL, P. et al. Protein hydrolysate vs. fish meal in compound diets for 10-day old sea bass Dicentrarchus labrax larvae. Aquaculture, v.171, p.109-119, 1999.

CARR, W.E.S. Chemical stimulation of feeding behaviour. In: HARA, T.J. Chemoreception in fishes. Amsterdam: Elsevier, 1982. p.259-273.

CARVALHO, A.P.; ESCAFFRE, A.M.; OLIVA-TELES, A. et al. First feeding of common carp larvae on diets with high levels of protein hydrolysates. Aquaculture International, v.5, p.361-367, 1997.

CATACUTAN, M.R.; COLOSO, R.M. Effect of dietary protein to energy ratios on growth, survival, and body composition of juvenile Asian seabass, Lates calcarifer. Aquaculture, v.131, p.125-133, 1995.

CHO, C.Y. Effects of dietary protein and lipid levels on energy metabolism of rainbow trout (Salmo gairdneri). In: EKERN, A.; SUNDSTL, F. Energy metabolism of farm animals. London: European Association for Animal Production, 1982. p.175183.

CHO, C.Y. Fish nutrition, feeds, and feeding: with special emphasis on salmonid aquaculture. Food Reviews International, v.6, n.3, p.333-357, 1990.

CHOUBERT, G.; DE LA NOÜE, J.; LUQUET, P. Continuous quantitative automatic collector for fishes feces. The Progressive Fish Culturist, v.41, p.64-67, 1979.

CHRISTIANSEN, C.; KLUNGSOYR, L. Metabolic utilization of nutrients and the effects of insulin in fish. Comparative Biochemistry and Physiology, v.88, n.3, p.701-711, 1987. 
COYLE, S.D.; TIDWELL, J.H.; WEBSTER, C.D. Response of largemouth bass Micropterus salmoides to dietary supplementation of lysine, methionine, and highly unsaturated fatty acids. Journal of World Aquaculture Society, v.31, n.1, p.89-95, 2000.

CYRINO, J.E.P.; CASTAGNOLlI, N.; PEREIRA FILHO, M. Digestibilidade da proteína de origem animal e vegetal pelo matrinxã (Brycon cephalus GÜNTHER, 1869). In: SIMPÓSIO BRASILEIRO DE AQUICULTURA, 4., Cuiabá, 1986. Anais. Cuiabá, 1986. p.49-62.

CYRINO, J.E.P; PORTZ, L.; MARTINO, R.C. Retenção de proteína e energia em juvenis de "Black bass"Micropterus salmoides. Scintia agrícola, v.57, n.4, p.609$616,2000$.

DANIELS, W.H.; ROBINSON, E.H. Protein and energy requirements of red drum. Aquaculture, v.53, p.232-243, 1986.

DAVIS, D.A.; JIRSA, D.; ARNOLD, C.R. Evaluation of soybean proteins as replacements for menhaden fish meal in practical diets for red drum (S ciaenops ocellatus). Journal of the World Aquaculture Society, v.26, p.48-58, 1995.

DENG, D-F.; REFSTIE, S.; HUNG, S.S.O. Glycemic and glycosuric responses in white sturgeon (Acipenser transmontanus) after oral administration of simple and complex carbohydrates. Aquaculture, v.199, p.107-117, 2001.

De SILVA, S.S.; ANDERSON, T.A. Fish nutrition in aquaculture. London: Chapman \& Hall, 1995. 319p.

De SILVA, S.S.; DENG, D.F.; RAJENDRAM, V. Digestibility in goldfish fed diets with and without chromic oxide and exposed to sblethal concentrations of cadmium. Aquaculture Nutrition, v.3, p.109-114, 1997.

DIAS, J.; ALVAREZ, M.J.; DIEZ, A. et al. Regulation of hepatic lipogenis by dietary protein/energy in juvenile European seabass (Dicentrarchus labrax). Aquaculture, v.161, p.169-186, 1998.

ELLIS, R.W.; SMITH, R.R. Determining fat digestibility in trout using a metabolic chamber. Progressive Fish Culturist, v.46, p.116-119, 1984. 
EL SAYED , A-F.M.; TESHIMA, S. Protein and energy requirement of Nile tilapia, Oreochromis niloticus, fry. Aquaculture, v.103, p.55-63, 1992.

FALGE, R.; SCHPANOF, L.; JURSS, K. Amylase, esterase and protease activity in the intestine content of rainbow trout, Salmo gairdneri, Richardson after feeding with feed containing different amounts of starch and protein. Journal of Ichthyology, v.18, p.283-287, 1978.

FERNANDEZ, F.; MIQUEL, A.G.; MARTINEZ, R. et al. Dietary chromic oxide does not affect the utilization of organic components but can alter the utilization of mineral salts in gilthead sea bream Sparus aurata. Journal of Nutrition, v.129, p.10531059, 1999.

FAO. The state of world fisheries and aquaculture 1998. FAO, 1999. 128p.

FAO. The state of world fisheries and aquaculture 2002. FAO, 2002. 150p.

FORSYTHE, W.A. Soy protein, thyroid regulation and cholesterol metabolism. Journal of Nutrition, v.125, p.6195-6235, 1995.

FOWLER, L.G. Poultry by-product meal as dietary protein source in full Chinook salmon diets. Aquaculture, v.99, p.309-321, 1991.

FRANCIS, G.; MAKKAR, H.P.S.; BECKER, K. Antinutritional factors present in plant-derived alternate fish feed ingredients and their effects in fish. Aquaculture, v.199, p.197-227, 2001.

FREIRE, E.S. Avaliação biológica de sorgo alto e baixo tanino por meio do desempenho e digestibilidade em tilápia do Nilo (Oreochromis niloticus). Botucatu, 2002. 65p. Dissertação (Mestrado) - UNESP - Universidade Estadual Paulista "Júlio de Mesquita Filho".

FUKE, S.; KONOSU, S.; KAZUO, I. Identification of feed stimulants for red sea bream in the extract of marine worm Perinereis brevicirrus. Bulletin of Japanese Society of Scientific Fisheries, v.47, p.1631-1635, 1981.

FURUKAWA, A.; TSUKAHARA, $H$. On the acid digestion method for the determination of chromic oxide as an index substance in the study of digestibility of fish feed. Bulletin of Japanese Society of Scientific Fisheries, v.32, p.502-506, 1966. 
GARLING, D.M.; WILSON, R.P. Optimum dietary protein-to-energy ratios for channel catfish fingerlings, Ictalurus punctatus. Journal of Nutrition, v.106, p.1368-1375, 1976.

GATLIN, D.M.; POE, W.E.; WILSON, R.P. Protein and energy requirement of fingerling channel catfish for maintenence and maximun growth . Journal of Nutrition, v.116, p.2121-2131, 1986.

GATLIN III, D.M. Nutrition and feeding of red drum and hybrid striped bass. In: CHANG, Y.K.; WANG, S.S. Advances in extrusion technology. Lancaster: Technomic Publ., 1999. p.43-52.

GIDUCK, S.A.; THREATTE, R.M.; KARE, M.R. Cephalic reflexes: their role in digestion and possible roles in absortion and metabolism. Journal of Nutrition, v.117, p.1191-1196, 1987.

GODDARD, J.S.; McLEAN, E. Acid-insoluble ash as an inert reference material for digestibility studies in tilapia, Oreochromis aureus. Aquaculture, v.194, p.93-98, 2001.

GODOY, M.P. Observações sobre a adaptação do "black bass" (Micropterus salmoides) em Pirassununga, Estado de São Paulo. Revista Brasileira de Biologia, v.14, n.2, p.32-38, 1954.

GOODWIN, A.E.; LOCHMANN, R.T.; TIEMAN, D.M. et al. Massive hepatic necrosis and nodular regeneration in largemouth bass fed diets high in available carbohydrate. Journal of the World Aquaculture Society, v.33, n.4, p.466-477, 2002

HANLEY, F. The digestibility of foodstuffs and the effects of feeding selectivity on digestibility determinations in tilapia, Oreochromis niloticus (L). Aquaculture, v.66, p.163-179, 1987.

HEPHER, B. Nutrition of pond fishes. Cambridge: Cambridge University Press, 1985. 388 p.

HILLESTAD, M.; ASGARD, T.; BERGE, G.M. Determination of digestibility of commercial salmon feeds. Aquaculture, v. 179, p. 81-94, 1999.

HUGHES, S.G. Single-feeding esponse of Chinook salmon fry to potential feed intake modifiers. Progressive Fish-Culturist, v.55, p.40-42, 1985. 
HUGHES, S.G. Response of first-feeding spring Chinook Salmon to four potential chemical modifiers of feed intake. The Progressive Fish Culturist, v.53, p.17-20, 1991.

HUTCHINS, C.G.; RAWLES, S.D.; GATLIN, D.M. Effects of dietary carbohydrate kind and level on growth, body composition and glycemic response of juvenile sunshine bass (Morone chrysops x M. saxatilis ). Aquaculture, v.161, p.187199, 1998.

JAFRI, E.A.K. Effect of dietary carbohydrate-to-lipid ratio on growth and body composition of walking catfish (Clarias batrachus). Aquaculture, v.161, p.159-168, 1998.

JEONG, K.; TAKEUCHI, T.; WATANABE, T. Improvement of nutritional quality of carbohydrate ingredients by extrusion process in diets of red sea bream. Nippon Suisan Gakkaishi, v.57, p.1543-1549, 1991.

KAUSHIK, S.J.; MÉDALE, F. Energy requirements, utization and dietary supply to salmonids, Aquaculture, v.124, p.81-97, 1994.

KEARNS, J.P. Advantages of extrusion cooking and comparisons with the pelleting process for aquatic feeds. In: PEOPLE'S REPUBLIC OF CHINA AQUACULTURE AND FEED WORKSHOP, Beijing, 1989. Proceedings. Beijing: American Soybean Association, 1989. p.245-269.

KEARNS, J.P. Ingredient consideration, preparation of feeds, selection of extrusion equipement and automatic controls for extrusion pet and aquatic feeds. In: CHANG, Y.K.; WANG, S.S. Advances in extrusion technology. Lancaster: Technomic Publ., 1999. p.97-106.

KETOLA, H.G. Mineral nutrition: effects of phosphorus in trout and salmon feeds in water pollution. In: COWEY, C.B.; MACKIE, A.M.; BELL, J.G. Nutrition and feeding of fish. New York: Academic Press, 1985. p.465-473.

KIKUCHI, K. use of defatted soybean meal as a substitute for fish meal in diets of Japanese flounder (Paralichthys olivaceus). Aquaculture, v.179, p.3-11, 1999. 
KROGDAHL, A. Alternative protein sources from plant contain antinutrients affecting digestion in salmonids. In: INTERNATIONAL SYMPOSIUM ON FEEDING AND NUTRITION IN FISH, Toba, 1989. Proceedings. Toba: IUNS, 1989. p. 253-261.

KUBITZA, F. Substituição total da farinha de peixe pelo farelo de soja em rações para alevinos de pacu (Piaractus mesopotamicus Holmberg, 1987), suplementadas com metionina. Piracicaba, 1990. 80p. Dissertação (Mestrado) - Escola Superior de Agricultura “Luiz de Queiroz”, Universidade de São Paulo.

KUBITZA, F. Preparo de rações e estratégias de alimentação no cultivo intensivo de peixes carnívoros. In: SIMPÓSIO INTERNACIONAL SOBRE NUTRIÇÃO DE PEIXES E CRUSTÁCEOS, Campos do Jordão, 1995. Anais. Campos do Jordão: CBNA, 1995. p.91-115.

KUBITZA, F.; LOVSHIN, L.L. Pond production of pellet-fed advanced juvenile and food-size largemouth bass. Aquaculture, v.149, p.253-262, 1997.

KUBITZA, F.; LOVSHIN, L.L.; LOVELL, R.T. Identification of feed enhancers for juvenile largemouth bass Micropterus salmoides. Aquaculture, v.148, p.191-200, 1997.

LEE, D.J.; PUTNAM, G.B. The response of rainbow trout to varying protein/energy ratios in a test diet. Journal of Nutrition, v.103, n.11, p.916-922, 1973.

LI, M.; LOVELL, R.T. Comparison of satiate feeding and restricted feeding of channel catfish with various concentrations of dietary protein in production ponds. Aquaculture, v.103, p.165-175,1992a.

LI, M.; LOVELL, R.T. Growth, feed efficiency and body composition of second and third year channel catfish fed various concentrantios of dietary protein to satiety in production ponds. Aquaculture, v.103 p.153-163,1992 b.

LIED, E.; JULSHAMN, K.; BRAEKKAN, O.R. Determination of protein digestibility in Atlantic cod (Gadus morhua) with internal and external indicators. Canadian Journal of Fisheries and Aquatic Sciences, v.39, p.854-861, 1982.

LOVELL, R. T. Use of soybe an products in diets for aquaculture species. Saint Louis: American Soybean Association, 1984a. 16p. (Technical Bulletin,AQ21-90 $6 / 7)$. 
LOVELL, R.T. The yellow fat problem in fish flesh. Aquaculture Magazine, v. 10, n.4, p. 39-40, $1984 b$.

LOVELL, R.T. Weight gain versus protein gain for evaluating fish feeds. Aquaculture Magazine, v. 12, p. 45-47, 1986.

LOVELL, R.T. Use of soybean products in diets for aquaculture species. In: PEOPLE'S REPUBLIC OF CHINA AQUACULTURE AND FEED WORKSHOP, Beijing, 1988. Proceedings. Beijing: American Soybean Association, 1988. p. 335361.

LOVELL, R. T. Nutrition and feeding of fish. New York: Van Nostrand Reinhold, 1989. 260p.

LOVELL, R. T. Nutrition of Aquaculture Species. Journal of Animal Science, v.69, p.4193-4200, 1991.

McGOOGAN, B.B.; GATLIN, D.M. Effects of replacing fish meal with soybean meal in diets for red drum Sciaenops ocellatus and potential for palatability enhancement. Journal of the World Aquaculture Society, v.28, n.4, p.374-385, 1997.

McGOOGAN, B.B; REIGH, R.C.; Apparent digestibility of selected ingredients in red drum (Sciaenops ocellatus) diets. Aquaculture, v.141, p. 233-244, 1996.

MENDONÇA, J.O; SENHORINI, J.A.N.; FONTES, A. et al. Influência da fonte protéica no crescimento do matrinxã, Brycon cephalus GÜNTHER, 1869 (Teleostei, Characidae), em viveiros. Boletim Técnico do CEPTA, v.6, p.51-57, 1993.

MILLAUER, C.; LOSENEGGER, H.R. Production of aquaculture feeds. In: CHANG, Y.K.; WANG, S.S. Advances in extrusion technology. Lacaster: Technomic Publishing, 1999. p. 377-406.

MILLIKIN, M.R. Effects of dietary protein concentration on growth, feed efficiency, and body composition of age- 0 striped bass. Transactions of the American Fisheries Society, v.111, p.373-378, 1982.

MILLWARD, D.J. The nutritional regulation of muscle growth and protein turnover. Aquaculture, v.79, p. 1-28, 1989. 
MIRANDA, E.C.; PEZZATO, A.C.; PEZZATO, L.E. et al. Disponibilidade aparente de fósforo em ingredients pela tilápia do Nilo (Oreochromis niloticus). Acta Scieniarum, v.22, n.3, p.669-675, 2000.

MOHSEN, A.A.; LOVELL, R.T. Partial substitution of soybean meal with animal protein sources in diets for channel catfish. Aquaculture, v.90, p.303-311, 1990.

MORAES, G.; OLIVEIRA, M.C.; RATIN, F.T. The metabolic pattern changes of Hoplias malabaricus from normoxia to hypoxia conditions. Revista Brasileira de Biologia, v.56, n.2, p.191-196, 1996.

MORALES, A.E.; CARDENETE, G.; SANZ, A. et al. Re-evaluation of crude fibre and acid-insoluble ash as inert markers, alternative to chromic oxide, in digestibility studies with rainboe trout (Oncorhynchus mykiss). Aquaculture, v.179, p.71-79, 1999.

MURRAY, M.W.; ANDREWS, W.; DELOACH, H.L. Effects of dietary lipids, dietary protein and environmental temperature on growth, feed conversion and body composition of channel catfish. Journal of Nutrition, v.107, p.272-280, 1997.

NAGAI, M.; IKEDA, S. Carbohydrate metabolis in fish. I. Effects of starvation and dietary composition on the blood glucose level and the hepatopancreatic glycogen and lipid contents in carp. Bulletin of Japanese Society of Scientific Fisheries, v.37, p.404-409, 1971a.

NAGAI, M.; IKEDA, S. Carbohydrate metabolis in fish. I. Effects of dietary composition on metabolism of glucose- $6-{ }^{14} \mathrm{C}$ in carp. Bulletin of Japanese Society of Scientific Fisheries, v.37, p.410-414, 1971b.

NATIONAL RESEARCH COUNCIL. Nutrient requirement of fish. Washington: National Academic Press, 1993. 114p.

NENGAS, I.; ALEXIS, M.N.; DAVIES, S. High inclusion levels of poultry meals and related byproducts in diets for gilthead seabream Sparus aurata L. Aquaculture, v.179, p.13-23, 1999.

NG, W.K.; WILSON, R.P. Chromic oxide inclusion in the diet does not affect glucose utilization or chromium retention by channel catfish, Ictalurus punctatus. Journal of Nutrional, v.127, p.2357-2362, 1997. 
OlIVA TELES, A.; CERQUEIRA, A.L; GONÇALVES, P. The utilization of diets containing high levels os fish hydrolysate by turbot (Scophthalmus maximus) juveniles. Aquaculture, v.179, p.195-201, 1999.

OSTRENSKY, A.; BORGUETTI, J.R.; PEDINI, M. Situação atual da aqüicultura brasileira e mundial. In: VALENTI, W. C.; POLI, C. R.; PEREIRA, J.A. et al. Aquiicultura no Brasil: bases para um desenvolvimento sustentável. Brasília: CNPq, 2000. cap. 12, p.353-382

PAGE, J.W.; ANDREWS, J.W. Interactions of dietary levels of protein and energy on channel catfish (Ictalurus punctatus). Journal of Nutrition, v.103, p.1339-1346, 1973.

PALMER, T.N.; RYMAN, B.E. Studies on oral glucose intolerance in fish. Journal of Fish Biology, v.4, p.311-319, 1972.

PAPATRYPHON, E.; SOARES JUNIOR, J.H. Identification of feeding stimulants for striped bass, Morone saxatilis. Aquaculture, v.185, p.339-352. 2000a.

PAPATRYPHON, E.; SOARES JUNIOR, J.H. The effect of dietary stimulants on growth performance of striped bass, Morone saxatilis, fed-a-plant feedstuff-based diet. Aquaculture, v.185, p.329-338, 2000b.

PAPATRYPHON, E.; SOARES JUNIOR, J.H. Optimizing the levels of feeding stimulants for use in high-fish meal and plant feedstuff-based diets for striped bass Morone saxatilis. Aquaculture, v.202, p. 279-288, 2001.

PERAGÓN, J.; BARROSO, J.B.; GARCÍA-SALGUERO, L. et al. Carbohydrates affect protein-turnover rates, growth, and nucleic acid content in the white muscle of rainbow trout (Oncorhynchus mykiss). Aquaculture, v.179, p.425-437, 1999.

PÉREZ, L.; GONZALES, H.; JOVER, M. et al. Growth of European sea bass fingerlings (Dicentrarchus labrax) fed extruded diets containing varying levels of protein, lipid and carbohydrate. Aquaculture, v.156, p.183-193, 1997.

PEZZATO, L. E. Alimentos convencionais e não-convencionais disponíveis para a indústria da nutrição de peixes e crustáceos. In: SIMPÓSIO INTERNCIONAL SOBRE NUTRIÇÃO DE PEIXES E CRUSTÁCEOS, Campinas, 1995. Anais. Campinas: CBNA, 1995. p.34-52. 
PEZZATO, L. E. Qualidade dos ingredientes, processamento e eficiência alimentar em aqüicultura. In: SIMPÓSIO BRASILEIRO DE AQÜICULTURA, Goiânia, 2002. Anais. Goiânia: IMBRAQ, 2002. p.62-75.

PFEFFER, E.; BECKMANN TOUSSAINT, J.; HENRICHFREISE, B. et al. Effect of extrusion on efficiency of utilization of maize starch by rainbow trout (Oncorhynchus mykiss). Aquaculture, v.96, p.293-303, 1991.

PFEFFER, E.; KINSINGER, S.; RODERUTSCORD, M. Influence of the proportion of poultry slaughter by-product and of untreated or hydrothermally treated legume seeds in diets for rainbow trout, Oncorhynchus mykiss (Walbaum), on apparent digestibilities of their energy and organic compounds. Aquaculture Nutrition, v.1, p.111-117, 1995.

PODOSKINA, T.A.; PODOSKIN, A.G.; BEKINA, E.N. Efficiency of utilization of some potato starch modifications by rainbow trout (Oncorhynchus mykiss). Aquaculture, v.152, p.235-248, 1997.

PORTZ, L. Relação energia:proteína na nutrição do "black bass" (Micropterus salmoides). Piracicaba, 1999. 88p. Dissertação (Mestrado) - Escola Superior de Agricultura “Luiz de Queiroz”, Universidade de São Paulo.

PORTZ, L. Utilização de diferentes fontes protéicas em dietas formuladas pelo conceito de proteína ideal para o "black bass" (Micropterus salmoides). Piracicaba, 2001. 111p. Tese (Doutorado) - Escola Superior de Agricultura "Luiz de Queiroz", Universidade de São Paulo.

PORTZ, L; CYRINO, J.E.P.; MARTINO, R.C. Growth and body composition of juvenile largemouth bass Micropterus salmoides in response to dietary protein and energy levels. Aquaculture Nutrition, v.7, p.247-254, 2001.

POSTON, H. A. Effect of protein and caloric sources in blood serum protein of immature brown trout. Fisheries Research Bulletin, v.24, p.19-23, 1965.

REFSTIE, S.; HELLAND, S.J.; STOREBAKKEN, T. Adaptation to soybean meal in diets for rainbow trout, Oncorhynchus mykiss. Aquaculture, v.153, p.263-272, 1997. 
REFSTIE, S; KORSOEN, O.J.; STOREBAKKEN, T. et al. Differing nutritional responses to dietary soybean meal in rainbow trout (Oncorhynchus mykiss) and Atlantic salmon (Salmo salar). Aquaculture, v.190, p.49-63, 2000.

REGOST, C.; ARZEL, J.; KAUSHIK, S.J. Partial or total replacement of fish meal by corn gluten meal in diet for turbot (Psetta maxima). Aquaculture, v.180, p.99-117, 1999.

REIGH, R.C.; ELLIS, S.C. Effects of dietary soybean and fish-protein ratios on growth and body composition of red drum (Sciaenops ocellatus) fed isonitrogenous diets. Aquaculture, v.104, p.279-292, 1992.

RICHARDSON, N.L.; HIGGS, D.A.; BEAMES, R.M. et al. Influence of dietary calcium, phosphorus, zinc and sodium phytate level on cataract incidence, growth and histopathology in juvenile Chinook salmon (Oncorhynchus tshawtscha). Journal of Nutrition, v.115, p.553-567, 1985.

RILEY, W.W.; HIGGS, D.A.; DOSANJH, B.S. et al. Influence of dietary amino acid composition on thyroid function of juvenile rainbow trout, Oncorhynchus mykiss. Aquaculture, v.112, p.253-269. 1993.

RINGO, E. Does chromic oxide $\left(\mathrm{Cr}_{2} \mathrm{O}_{3}\right)$ affect faecal lipid and intestinal bacterial flora in Artic charr, Salvelinus alpinus. Aquaculture Fisheries Management, v.24, p.767-776, 1993.

ROBAINA, L.; CORRAZE, G.; AGUIRRE, P. et al. Digestibility, postprandial ammonia excretion and selected plasma metabolitos in european sea bass (Dicentrarchus labrax) fed pelleted or extruded diets with or without wheat gluten. Aquaculture, v.179, p.45-56, 1999.

ROBAINA, L.; IZQUIERDO, M.S.; MOYANO, F.J. et al. Soybean and lupin seed meals as protein sources in diets for gilthead seabream (Sparus aurata): nutritional and histological implications. Aquaculture, v.130, p.219-233, 1995.

ROBINSON, E.H.; LI, M.H. Low protein diets for channel catfish Icatalurus punctatus raised in earthen ponds at high density. Journal of the World Aquaculture Society, v. 28, n. 3, p.224-229, 1997. 
ROBINSON, E.H.; WILSON, R.P.; POE, W.E. Arginine requirement and apparent absence of a lysine-arginine antagonist in fingerling channel catfish. Journal of Nutrition, v.11, p.46-52, 1981.

ROJAS, J.B.U.; VERDEGEN, M.C.J. Effect of the protein:energy ratio in isocaloric diets on the growth of Cichlasoma managuense (Günther 1869). Aquaculture, v.25, p.631-637, 1994.

RYCHLY, J.; SPANNHOF, L. Nitrogen balance in trout. 1. Digestibility of diets containing varying levels of protein and carbohydrate. Aquaculture, v.16, p.39-46, 1979.

SAMANTARY, K.; MOHANTY, S.S. Interactions of dietary levels of protein and energy on fingerling snakehead, Channa striata. Aquaculture, v.156, p.241-249, 1997.

SAMPAIO, A.M.B.M. Relação energia:proteína na nutrição do tucunaré Cichla sp. Piracicaba, 1998. 49p. Dissertação (Mestrado) - Escola Superior de Agricultura "Luiz de Queiroz", Universidade de São Paulo.

SAMPAIO, A.M.B.M.; KUBITZA, F.; CYRINO, J.E.P. Relação energia:proteína na nutrição do tucunaré. Scientia Agricola, v.57, n.2, p.213-219, 2000.

SARGENT, J.; HENDERSON, R.J.; TOCHER, D.R. The lipids. In: HALVER, J. (Ed.). Fish nutrition. Washington: Academic Press, 1989. cap.4, p.153-217.

SAS INSTITUTE. SAS user's guide : statistics. 5.ed. Cary, 1985. 378p.

SATOH, S.; POE, W.E.; WILSON, R.P. Effect of supplemental phyate and/or tricalcium phosphate on weight gain, feed efficiency and zinc content in vertebrae of channel catfish. Aquaculture, v. 80, p.155-161, 1989.

SEENAPPA, D.; DEVARAJ., K.V. Effect of different levels of protein, fat and carbohydrate on growth, feed utilization and body carcass composition of fingerlings in Catla catla (Ham.). Aquaculture, v.129, p.243-249, 1995.

SHIAU, S.Y.; LIANG, H.S. Carbohydrate utilization and digestibility by tilapia (Oreochromis niloticus x Oreochromis aureus), are affected by chromic oxide inclusion in the diet. Journal of Nutrition v.125, p.976-982, 1995. 
SHIAU, S.Y.; LIN, S.F. Carbohydrate utilization by tilapia (Oreochromis niloticus $\mathrm{x}$ Oreochromis aureus). Journal of Nutrition, v.123, p.1747-1753, 1993.

SHIAU, S.Y.; SHY, S.M. Dietary chromic oxide inclusion level required to maximize glucose utilization in hybrid tilapia (Oreochromis niloticus x Oreochromis aureus). Aquaculture, v.161, p.357-364, 1998.

SHIMIZU, C.; IBRAHIM, A.; TOKORO, T. et al. Feeding stimulation in sea bream, Pagrus major, fed diets supplemented with Antartic Krill meals. Aquaculture, v.89, p.43-53, 1990.

SHIPTON, T.A.; BRITZ, P.J. An assessment of the use of chromic oxide as a marker in protein digestibility studies with haliotis midae L. Aquaculture, v.203, p.69-83, 2001.

SMALL, B.C.; AUSTIC, R.E.; JOSEPH Jr., H.S. Amino acid availability of four practical feed ingredients fed to striped bass Morone saxatilis. Journal of the World Aquaculture Society, v.30, n.1, p.58-64, 1999.

SMITH, R.R. Metabolizable energy of feedstuffs for trout. Feedstuffs, v.48, p.16-21, 1976.

SMITH, R.R. Nutritional energetics. In: HALVER, J. (Ed.). Fish nutrition. Washington: Academic Press, 1989. cap.1, p.1-29.

SMITH, R.R.; PETERSON, M.C.; ALLRED, A.C. The effect of leaching on apparent digestion coefficients indetermining digestibility and metabolizable energy of feedstuffs for salmonids. Progressive Fish Culturist, v.33, p.132-134, 1980.

SOENGAS, J.L.; ALBEGUNDE, M.; ANDRÉS, M.D. Gradual transfer to sea water of rainbow trout: Effects on liver carbohydrate metabolism. Journal of Fish Biology, v.47, n.3, p.466-478, 1995.

SPANNHOF, L.; PLANTIKOW, H. Studies on carbohydrate digestion in rainbow trout. Aquaculture, v.30, p.95-108, 1983.

SPINELLI, J.; HOULE, C.R.; WEKELL, J.C. The effect of phytates on the growth of rainbow trout (Salmo gairdneri) fed purified diets containing varying quantities of calcium and magnesium. Aquaculture, v.30, p.71-84, 1983. 
SPYRIDAKIS, R.; METAILLER, R.; GABAUDAN, J. et al. Studies on nutrient digestibility in European sea bass (Dicentrarchus labrax). I. Methodological aspects concerning faeces collection. Aquaculture, v.77, p.61-70, 1989.

STEFFENS, W. Principles of fish nutrition. Chichester: Ellis Harwood, 1989. p.184 208: Energy requirement.

STONE, D.A.J.; ALLAN, G.L; PARKINSON, S. et al. Replacement of fish meal in diets for Australian silver perch, Bidyanus bisdyanus. III. Digestibility and growth using meat meal products. Aquaculture, v.186, p.311-326, 2000.

STOREBAKKEN, T.; KVIEN, I.S.; SHEAER, K.D. et al. Estimation of gastrointestinal evacuation rate in Atlantic salmon (Salmo salar) using inert markers and collection of faeces by sieving: evacuation of diets with fish meal, soybean meal or bacterial meal. Aquaculture, v.172, p.291-299, 1999.

STOREBAKKEN, T.; SHEARER, K.D.; BAEVERFJORD, G. et al. Digestibility of macronutrients, energy and amino acids, absorption of elements and absence of intestinal enteritis in Atlantic salmon, Salmo salar, fed diets with wheat gluten. Aquaculture, v.184, p.115-132, 2000.

STOREBAKKEN, T.; SHEARER, K.D.; REFSTIE, S. et al. Interactions between salinity, dietary carbohydrate source and carbohydrate concentration on the digestibility of macronutrients and energy in rainbow trout (Oncorhynchus mykiss). Aquaculture, v.163, p.347-359, 1998.

STRYER, L. Metabolismo do glicogênio. In: STRYER, L. Bioquímica. Rio de Janeiro: Guanabara, 1971. cap.19, p.371-386.

SUGIURA, S.H.; DONG, F.M.; RATHBONE, C.K. et al. Apparent protein digestibility and mineral availabilities in various feed ingredients for salmonid feeds. Aquaculture, v.159, p.177-202, 1998.

SULLIVAN, J.A.; REIGH, R.C. Apparent digestibility of selected feedstuffs in diets for hybrid striped bass (Morone saxatilis x Morone chrysops). Aquaculture, v.138, p.313-322, 1995. 
TACON, A.G.J.; JACKSON, A.J. Utilization of conventional and unconventional protein sources in practical fish feeds. In: COWEY, C.B.; MACKIE, A.M.; BELL, J.G. Nutrition and feeding in fish: utilization of conventional and unconventional protein sources in practical fish feeds. London: Academic Press, 1985. 489p.

TAKEUCHI, T. Essencial fatty acids requirement of aquatic animals with emphasis on fish larvae and fingerlings. Reviews in Fisheries Science, v.5, n.1, p.1-25, 1997.

TAKEUCHI, T.; JEONG, K.S.; WATANABE, T. Availability of extruded carbohydrate ingredients to rainbow trout Oncorhynchus mykiss and carp Cyprinus carpio. Nippon Suisan Gakkaichi, v.56, p.1839-1845, 1990.

TAKII, K.; SHIMENO, S.; TAKEDA, M. et al. The effect of feeding stimulants in diet on digestive enzyme activities of eel. Bulletin of Japanese Society of Scientific Fisheries, v. 52, p.1449-1454, 1986.

TIBALDI, E.; BERALDO, P.; VOLPELLI, L.A. et al. Growth response of juvenile dentex (Dentex dentex L.) to varying protein level and protein to lipid ratio in practical diets. Aquaculture, v.139, p.91-99,1996.

UFODIKE, E.B.C.; MATTY, A.J. Growth responses and nutrient digestibility in mirror carp (Ciprinus carp) fed different levels of cassava and rice. Aquaculture, v.31, p.41-50, 1983.

VENTURIERI, R. Pesque pague no Estado de São Paulo. São Paulo: Eco Associação para estudos do ambiente, 2002. 151p.

VIEGAS, E.M.M. Processamento de pescados e aproveitamento de resíduos. In: SIMPÓSIO BRASILEIRO DE AQÜICULTURA, Goiânia, 2002. Anais. Goiânia: SIMBRAQ, 2002. p.76-83.

WATANABE, T. Fish nutrition. In: TAKEUCHI, T. Fish nutrition and mariculture. Tokyo: Aquatic Biosciences, 1988. cap.1, p.179-233.

WATANABE, T.; PONGMANEERAT, J. Pontential of soybean meal as a protein source in extruded pellets for rainbow trout. Nippon Suisan Gakkaishi, v.59, p.1415-1423, 1993.

WATANABE, T.; VERAKUNPIRIYA, V.; WATANABE, K. et al. Feeding of rainbow trout with non-fish meal diets. Fishery Science, v.63, p.258-266, 1997. 
WEBSTER, C.D.; GOODGAME-TIU, I.S.; TIDWELL, J.H. Total replacement of fih meal by soybean meal, with various percentages of supplemental L.methionine, in diets for blue catfish, Ictalurus furcatus (Lesueur). Aquaculture Research, v.26, p.299-306, 1995.

WEBSTER, C.D.; THOMPSON, K.R.; MORGAN, A.M. et al. Use of hempseed meal, poultry by-product meal, and canola meal in practical diets without fish meal for sunshine bass (Morone chrysops x M. sxatilis). Aquaculture, v.188, p.299-309, 2000.

WEBSTER, C.D.; TIU, L.G.; TIDWELL, J.H. Effects of replacing fish meal in diets on growth and body composition of palmetto bass (Morone saxatilis x Morone chrysops) raised in cages. Journal of Applied Aquaculture, v.7, n.1, p.53-67, 1997.

WICKER, A.M.; JOHNSON, W.E. Relationships among fat content, condition factor, and first year survival of Florida largemouth bass. Transactions of the Ame rican Fisheries Society, v.116, p.264-271, 1987.

WILSON, R.P. Amino acids and proteins. In: HALVER, J. (Ed.). Fish nutrition. Washington: Academic Press, 1989. cap.3, p.111-151.

WILSON, R.P. Utilization of dietary carbohydrate by fish. Aquaculture, v.124, p.6780, 1994.

WILSON, R.P.; POE, W.E. Apparent digestibility of protein and energy in feed ingredients for channel catfish. Progressive Fish Culturist, v.47, p.154-158, 1985.

WINFREE, R.A.; STICKNEY, R.R. Effects of dietary protein and energy on growth, feed conversion efficiency and body composition of Tilapia aurea. Journal of Nutrition, v.111, p.1001-1012, 1981.

XUE, M.; CUI, Y. Effect of several feeding stimulants on diet preference by juvenile gibel carp (Carassius auratus gibelio), fed diets with or without partial replacement of fish meal by meat and bone meal. Aquaculture, v.198, p.281-292, 2001.

ZEITOUN, I.H.; ULLREY, D.E.; MAGEE, W.T. et al. Quantifying nutrient requirements of fish. Journal of the Fisheries Research Board of Canada, v.33, p.167-172, 1976. 